Isabelle Fiorelli Silva

\title{
Fetiche e resitência na Política educacional do Paraná: um estudo de caso sobre a gestão escolar e sua relação com a democratização do ensino
}

Dissertação apresentada ao Programa de Pós Graduação - Mestrado em Educação da Faculdade de Educação na Universidade de São Paulo, USP, Brasil.

Ano de Obtenção: 2005. Orientador: Rubens Barbosa de Camargo. Palavras-chave: política educacional; gestão da educação. 
Ao Igor Gabriel, meu filho, demonstração plena de amor, beleza, alegria, compreensão e curiosidade.

À Margaret, mãe guerreira, fonte de conforto e proteção.

A lleizi, fortaleza de mulher, cujo papel de irmã mais velha_tamanha é sua competência_ se mistura ao papel maternal. 


\section{AGRADECIMENTOS}

Ao programa de pós-graduação da USP-São Paulo, que sempre me atendeu com respeito e compromisso.

Ao professor Rubens Barbosa de Camargo que, ao me receber, demonstrou compreensão e dedicação. Suas orientações e incentivos foram fundamentais nesse processo de trabalho.

Os meus agradecimentos são também aos colegas do grupo de pesquisa (UEL e UNIOSTE), principalmente a Ângela Maria Hidalgo, Edmilson Lenardão, Sandra Garcia, Ana Lucia Aoyama, Eliane Cleide Czerrnisz, Maria da Graça Ferreira, Marleide Perrude e Ileizi L. Fiorelli Silva, que contribuíram significativamente para a obtenção dos pré-requisitos necessários a um pesquisador e pelo apoio em minha jornada acadêmica.

Ao CNPQ pelo apoio financeiro.

À minha irmã lleizi pelo apoio incondicional na minha caminhada estudantil, profissional e pessoal.

Aos meus irmãos Osvaldo e Marcella que cuidaram do meu filho tantas vezes para poder dedicar-me aos estudos.

À minha amada mãe Margaret pela dedicação incondicional em todos os momentos de minha vida. 
"O que importa na cultura de um povo é o atrito, a oposição, pois esses são os elementos que promovem o revigoramento e a vida de suas instituições". Anísio Teixeira $(1900-1971)$ 


\section{Siglário}

PMDB- Partido do Movimento Democrático Brasileiro

PFL- Partido da Frente Liberal

PT- Partido dos Trabalhadores

SAEB- Sistema Nacional de Avaliação da Educação Básica

ENEM- Exame Nacional para o Ensino Médio

MEC- Ministério da Educação

LDB- Lei de Diretrizes e Bases

BM- Banco Mundial

FMI- Fundo Monetário Internacional

BID- Banco Interamericano de Desenvolvimento

BIRD- Banco Internacional para a Reconstrução e o Desenvolvimento

APM- Associação de Pais e Mestres

\section{CE-Conselho Escolar}

SEED- Secretaria Estadual de Educação

MARE- Ministério da Administração e da Reforma do Estado

PQE- Projeto Qualidade do Ensino Público do Paraná

PROEM- Programa Expansão, Melhoria e Inovação no Ensino Médio do Paraná

PCN- Parâmetros Curriculares Nacionais

PPP- Projeto Político Pedagógico

FUNDEPAR- Fundação Educacional do Paraná 


\section{RESUMO}

A pesquisa objetivou analisar as práticas de gestão escolar presentes em duas escolas públicas de Londrina-PR, tentando perceber seu comprometimento com uma determinada concepção de gestão e evidenciar as formas e graus de absorção da política educacional do governo estadual de Jaime Lerner (1995-2002) no interior das escolas. Além disso, procurou-se desvelar as formas de adesão e/ou resistência à proposta de gestão compartilhada implementada no governo em questão, e, nas demonstrações de resistência a esse governo -enquadrado nos moldes neoliberais-, os possíveis embriões necessários ao processo de democratização do ensino.Tendo o fenômeno da gestão escolar como síntese de múltiplas determinações, buscou-se, na realidade concreta, analisar dialeticamente a relação com sua essência, que apontam ora para uma gestão democrática, consubstanciada em pressupostos de justiça social e igualdade de direitos, ora para uma gestão compartilhada vinculada aos pressupostos da privatização/mercantilização da esfera pública. Para tanto, houve pesquisa bibliográfica, pesquisa documental com a análise de alguns documentos do período selecionado e pesquisa de campo. Esta última pautou-se principalmente em entrevistas semi-estruturadas e acompanhamento dos canais de participação dos quais a escola pública dispõe. Considerou-se a complexidade e contraditoriedade inerentes à prática de gestão escolar, possibilitando práticas tanto de fetiche quanto de resistência em escolas públicas estaduais do Paraná. Estudar o modelo de gestão implementado nesses oito anos de reformas no estado e na educação permitiu desmistificar a gestão compartilhada, indicando sua essência antidemocrática, arquitetada sob uma capa de modernização e transformação, fetichizando a dimensão da gestão, como se ela fosse o elixir para todos os problemas da escola, favorecendo, assim, a manutenção da hegemonia neoliberal.

Palavras-chave: Política educacional, gestão escolar e democratização do ensino. 


\begin{abstract}
The research aimed to analyze the practices of scholastic administration present in two public schools in Londrina-PR, trying to perceive its compromising with a determinate conception of administration and to evidence the kinds and degrees of absorption of the educational politicies of Jaime Lerner's state government (19952002) inside the schools. Besides, it searched to attend the kinds of adhesion and/or resistance to the proposal of shared administration inserted in this government, and in the demonstrations of resistance for this government squared into the neo-liberals moulds, the possible and essential germs to the teaching. Having the phenomenon of scholastic administrations, it searched itself, in the concrete reality, to analyze dialeticly the relation with its essence that they point or for a democratic administration, consubstantiated in purposes of social justice and equality of rights, or for a shared administration entailed to the purposes of the privatization mercantilism of the public sphere. For as, there was bibliographic search and documental search with the analysis of some documents of the selected period and search of camps. This last search ruled itself, principally in semi-structured and attendance of the channels of participation that the public schools dispose. Considered itself the complexity and contrariety inherent to the practices of scholastic administration, allowing practices as fetish, as resistance in the public state schools of Paraná. To study the model of administration planted in these eight years of reforms in the state and in the education allowed to dismythicize theshared administration, indicating its antidemocratic essence, projected under a pretext of modernization and transformation, turning a fetish the dimension of the administration, like if it were the elixir for all problems of the school.
\end{abstract}

Key-words: Educational politicies, scholastic administration, democratization of the teaching. 


\section{SUMÁRIO}

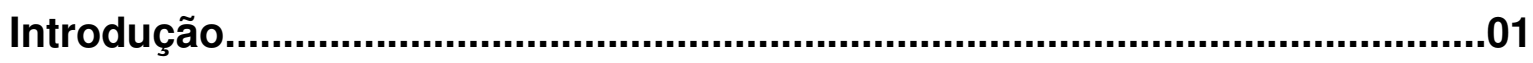

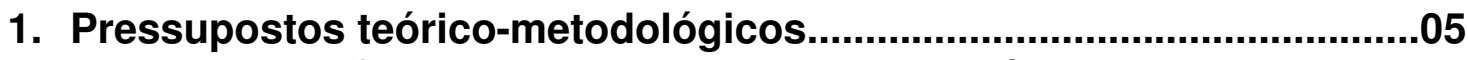

2. A administração escolar e seus elementos históricos.........................11

2.1 Administração escolar e gestão democrática da escola: aspectos conceituais e ideológicos............................................................23

2.2 A apropriação do paradigma da "qualidade total" pela gestão escolar e a

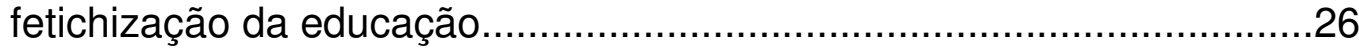

3. Democracia, educação e gestão escolar.............................................36

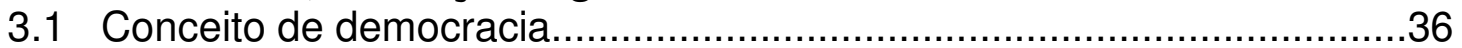

3.2 Concepção de homem, sociedade e educação: matrizes norteadoras de uma determinada concepção de democratização do ensino...................39

3.3 A democratização do ensino público, seus elementos constitutivos e sua relação com a gestão escolar.........................................................44

4. Fundamentos teóricos da gestão escolar: participação,

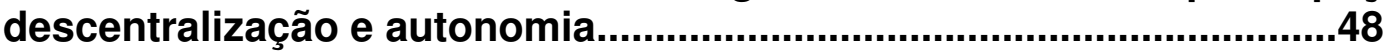

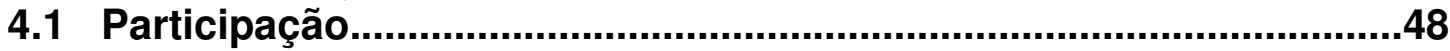

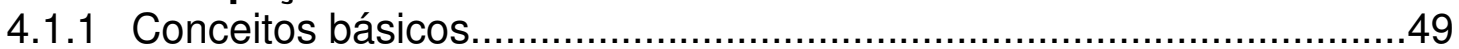

4.1.2 Bifurcação do conceito de participação: perspectiva transformadora contraposta à perspectiva neoliberal.................................................52

4.2 Descentralização...........................................................................57

4.2.1 A descentralização do Estado: perspectiva histórica........................57

4.2.2 A descentralização da educação no contexto da LDB 9.394/96...........60

4.2.3 A descentralização como estratégia neoliberal..................................62

4.2.4 A descentralização através da municipalização.................................65

4.2.5 A descentralização e sua relação com autonomia..............................67

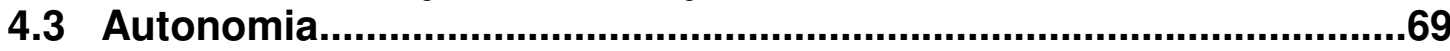

4.3.1 O significado da autonomia numa lógica neoliberal............................71

4.3.2 O significado da autonomia numa lógica progressista.........................74

5. Breve histórico da política educacional do Paraná................................80

5.1.1 O governo de José Richa (1983-1986)...........................................80

5.1.2 O governo de Álvaro Fernandes Dias (1987-1990).........................84

5.1.3 O governo de Roberto de Mello e Silva Requião (1991-1994)............87

5.1.4 O governo de Jaime Lerner (1995-2002): a ênfase na gestão

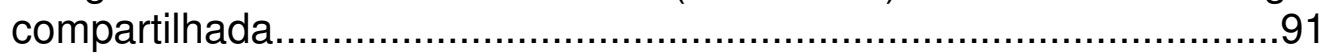

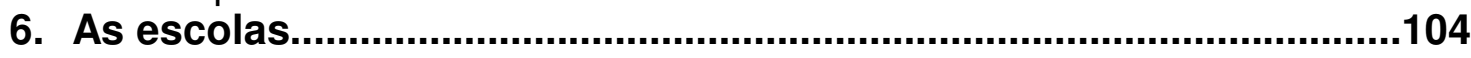

6.1 Caracterização da escola Domingas Guerreiro da Silva.......................107

6.2 Caracterização da escola Maria do Rosário Soares Brasil....................109

7. Democracia, gestão escolar, participação, autonomia e descentralização: análise dos dados coletados nas

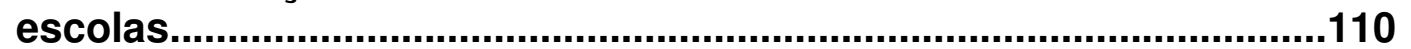

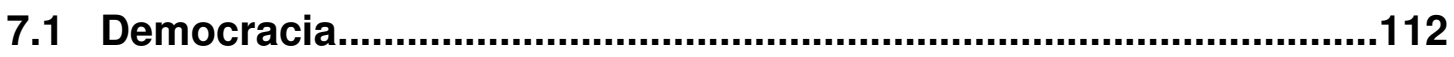

7.1.1 Escola Domingas Guerreiro da Silva.............................................112

7.1.2 Escola Maria do Rosário Soares Brasil..........................................116

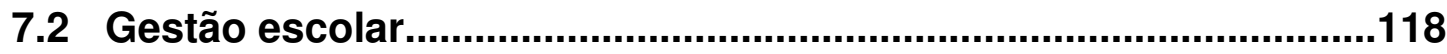


7.2.1 Escola

Domingas

Silva 118

Guerreiro

da

7.2.2 Escola Maria do Rosário Soares Brasil...........................................123

7.3 Participação......................................................................................127

7.3.1 Escola Domingas Guerreiro da Silva.........................................127

7.3.2 Escola Maria do Rosário Soares Brasil........................................135

7.4 Autonomia.....................................................................................140

7.4.1 Escola Domingas Guerreiro da Silva..........................................140

7.4.2 Escola Maria do Rosário Soares Brasil..........................................144

7.5 Descentralização................................................................................147

7.5.1 Escola Domingas Guerreiro da Silva............................................147

7.5.2 Escola Maria do Rosário Soares Brasil...........................................150

8. Considerações finais........................................................................152

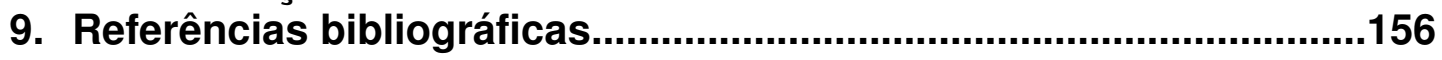

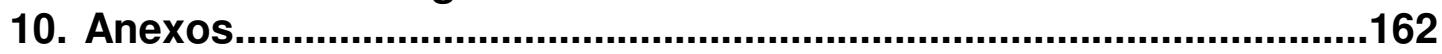




\section{INTRODUÇÃO}

\section{Delimitação do problema e objetivos}

No presente estudo pretendeu-se compreender a relação entre o modelo de gestão escolar proposto pela Secretaria de Educação do Estado do Paraná, iniciado no governo do PMDB (Partido do Movimento Democrático Brasileiro) com José Richa (1983-1986) e no cenário nacional, a partir de 1988, com a luta pela democratização do ensino público até os dias atuais (2005).

A partir da década de 90, as diretrizes neoliberais fazem com que a educação escolar fosse tratada como uma questão técnica e não política. Com isso, o discurso da igualdade e justiça social é substituído pelo de cidadania aliado à competivividade e às necessidades mercadológicas, emergindo, assim, uma tendência de intersecção cada vez maior entre as esferas pública e privada das escolas estaduais do Paraná. Além disso, estabelecem-se mecanismos de controle ${ }^{1}$ que ao mesmo tempo promovem a competitividade entre as unidades escolares, com sujeição à lógica mercadológica.

As políticas educacionais implementadas nas gestões dos governadores José Richa (PMDB, 1983-1986 _ saiu para candidatar-se Senador, deixando seu cargo para João Elisio Ferraz de Campos)_, Álvaro Dias (PMDB, 1987-1990), Roberto de Mello e Silva Requião (PMDB,1991-1994), Jaime Lerner (PFL, 1995-1998 e 1999 a 2002) e Roberto de Mello e Silva Requião (PMDB, 2003-2006), serão trabalhadas nesta pesquisa, valorizando-se alguns aspectos, em detrimento de outros, seguindo uma lógica de raciocínio embasada nas categorias de análise selecionadas.

Nos modelos de gestão abordados, pretendeu-se perceber as concepções e os mecanismos que os sustentam, além de analisar seus impactos nas escolas pesquisadas. Sobre a administração escolar como realidade empírica, foi feita uma reflexão com o intuito de desvendar suas determinações e contradições e de extrair de sua realidade as concepções e conteúdos político-educacionais que a consubstanciam, considerando-se seu caráter histórico, ou seja, os conteúdos e mecanismos percebidos

\footnotetext{
${ }^{1}$ Entendemos que o principal mecanismo de controle das políticas educacionais implementadas no Brasil e no Paraná é a avaliação. Assim, o SAEB e o ENEM, o "Provão" (no ensino superior) foram os mecanismos utilizados pelo Estado brasileiro no governo Fernando Henrique Cardoso (FHC) para controlar o desempenho individualizado e competitivo entre as instituições.
} 
fazem parte de uma construção histórica, de um processo de reforma nas políticas educacionais que se acirraram nas décadas de 80 e, principalmente, 90.

Com isso, existiu a preocupação em refletir criticamente a respeito da gestão na escola e perceber como ela se constituiu ao longo da história, consubstanciada em seus aspectos políticos, econômicos, sociais e educacionais.

As orientações emanadas do âmbito estatal são recebidas passivamente na escola, na maioria das vezes, uma vez que são anunciadas como inovadoras e democráticas, ressignificando conceitos importantes como autonomia, descentralização e participação, bandeiras embrionárias de movimentos populares progressistas. Por isso, o que se tem percebido é que tais orientações convergem para satisfação de interesses de pequenos grupos políticos, portanto, não para interesses das massas populares.

Diante disso, surgem os questionamentos:

1) Em quais condições sociais, políticas, econômicas e científicas emerge a formulação gestão democrática como mecanismo fundamental na configuração dos sistemas de ensino no Brasil e, em especial, no Paraná?

2) No processo de reconfiguração do Estado e da educação nos anos 80 s e 90s, quais concepções e práticas de gestão escolar ganham hegemonia e por quê?

3) Tais concepções não teriam fetichizado a gestão democrática da escola, tornando-a resultado ocultador das verdadeiras relações sociais presentes nos sistemas e nas unidades de ensino?

4) A insistência e a ênfase nos processos de gestão na escola não teriam desviado a atenção dos sujeitos das escolas, dos pesquisadores e dos responsáveis pelos sistemas do caráter mais eminentemente político da educação?

A metodologia adotada pelo $E s{ }^{2}{ }^{2}$, para implementação de sua proposta de gestão, buscou contemplar os conceitos de descentralização, de participação e de autonomia sendo por meio destes eixos que se pretende responder aos questionamentos acima expostos, principalmente porque é por meio do trabalho com

\footnotetext{
${ }^{2}$ É importante salientar que as Reformas Educacionais, intensificadas na década de 90, propostas pelo Estado e governos estaduais, foram produzidas fundamentalmente no governo de FHC, no âmbito nacional a partir do MARE (Ministério da Administração Federal e da Reforma do Estado), com base em seu Plano Diretor de Reforma do Estado e no MEC, que se vale da LDB, como suporte legal para suas ações posteriores; no âmbito internacional, é o Banco Mundial quem orienta tais reformas, inclusive contribuindo com diferentes aportes.
} 
estes conceitos que foi possível, no caso específico do Paraná, atribuir um caráter fetichizado à gestão escolar.

A adoção do modelo sistêmico de gestão e a transferência do ônus financeiro da atividade educativa para as famílias e a comunidade na qual a escola está envolvida, sobretudo por meio das Associações de Pais e Mestres (APMs), têm se constituído um dos mecanismos da gestão da Secretaria Estadual de Educação (SEED) no Paraná, que se intensificou e solidificou no governo de Jaime Lerner (1995-2002), para obter a "melhoria" da qualidade da educação no Estado, contribuindo para sua desresponsabilização, principalmente quanto ao financiamento do ensino público. Para tanto, o Estado utiliza manobras de descentralização e de desconcentração de responsabilidades, vinculando o conceito de autonomia à busca individualizada do sucesso, sendo isso passível de percepção no âmbito legal, seja na LDB (lei 9.394/96) seja em documentos do Estado do Paraná do período e no âmbito do cotidiano das escolas.

No Estado do Paraná houve um incentivo à competitividade entre as escolas, principalmente a partir da política educacional imprimida pelo governo Lerner, onde as escolas eram classificadas em unidades de "excelência" e de "não excelência". As primeiras foram as que conseguiram agregar o maior número de "avanços" (seguindo a administração central), principalmente em relação à manutenção do espaço físico, sem a participação do Estado (a essa competência o Estado denominava de "autonomia"). Além disso, seguiam orientações deste com afinco e sem resistência. As segundas foram as que, por motivos diversos, entre os quais as resistências a essa política privatista, não executaram passivamente os encaminhamentos propostos.

Como já foi mencionado, o período estudado abarca as gestões de José Richa (1983-1986), Álvaro Dias (1987-1990) Roberto Requião (1991-1994), Jaime Lerner (1995-1998 e 1999-2002) e Roberto Requião (2003-2006). Mas a análise será mais detalhada sobre a gestão de Jaime Lerner (95-02), quando a ênfase na gestão se intensifica e busca se solidificar implementando medidas para tal fim. Para tanto, foi feita não só pesquisa bibliográfica tanto em obras clássicas quanto em pesquisas de pós-graduação que analisaram a política educacional no Paraná no período selecionado, como também análise dos documentos ${ }^{3}$ e das escolas selecionadas.

\footnotetext{
${ }^{3}$ Os documentos selecionados para a pesquisa são: PQE (Projeto Qualidade do Ensino Público do Paraná, 1995-2001), PROEM (Projeto para o Ensino Médio), Construindo uma escola cidadã (1993), Avaliação qualitativa de mecanismos de descentralização escola (1998), Avaliação do Impacto da
} 
A pesquisa procurou realizar a análise das práticas de gestão presentes na escola, tentando perceber por meio do encaminhamento das ações concretas do cotidiano, aquelas que revelassem o comprometimento da escola com uma determinada concepção de gestão escolar, que evidenciasse a relação com a orientação política educacional do governo estadual, os mecanismos de envolvimento dos pais, professores e alunos nas tomadas de decisões e as práticas descentralizadoras e autônomas de que a escola dispõe.

Entendendo o fenômeno da gestão escolar como síntese de múltiplas determinações, buscou-se, na realidade concreta, analisar dialeticamente sua relação com sua essência, de forma a vislumbrar as condições objetivas existentes, que possibilitaram ou impediram uma gestão escolar progressista, consubstanciada em pressupostos de justiça social e igualdade de direitos, contrapondo-se à tendência neoliberal vinculada aos pressupostos da privatização/mercantilização da esfera pública.

"Sem ter presente uma adequada apreensão dessas manifestações concretas, os estudos que subsidiam propostas de políticas públicas em educação correm o risco de não se elevarem acima do senso comum, por lhes faltarem os elementos que Ihes dariam sustentação e validade teórica, posto que abstrair (...) as determinações essenciais, necessárias, explicativas do real concreto presente no cotidiano é construir generalizações sem sustentação empírica, é teorizar no vazio. A boa teoria é uma abstração do real, mas sentido positivo de sintetizá-lo, de 'por entre parêntesis' determinados aspectos circunstanciais ou particulares, para verificar o que existe de universal, de essencial, que the dá sentido e especificidade; é verificar, acerca de determinado fenômeno, quais são as leis que explicam seu movimento e constituição" (Paro, 2001:125).

Em meio às contradições, aos conflitos e às dificuldades cotidianas é possível encontrar tanto práticas que contribuem para o processo de democratização do ensino nas quais se percebem atitudes de resistência e crítica às propostas governamentais, quanto práticas de aceitação passiva e acrítica das orientações emanadas do Estado.

"Ignorar a contradição resulta numa atitude que leva ao conservadorismo, pois abstrair esse elemento é retirar da realidade seu caráter profundo de inacabamento. Ignorar a contradição é querer retirar do real o movimento e, por isso, é recurso próprio das ideologias dominantes, que, não podendo retirá-la das relações sociais, econômicas e políticas, representam-na como imaginariamente superada" (Cury, 1986:34).

Municipalização do Ensino Fundamental no Estado do Paraná (1996), Relatório Final do PQE (2002), Dez anos de Educação no Paraná (2001), Guia de Gestão Escolar (2002), Entendendo melhor a mudança organizacional (1996) e Caderno: Centro de Capacitação de Faxinal do Céu: Universidade do Professor (1998). 
Definidas estas dimensões da pesquisa realizada, almejou-se contribuir para a indicação de alguns traços da política educacional paranaense no período mencionado.

\section{PRESSUPOSTOS TEÓRICO-METODOLÓGICOS}

Num processo de pesquisa, as dificuldades começam quando a explicação pretendida se centra na busca da relação entre a realidade concreta e os processos sociais mais amplos (conhecimento empírico e teórico- segundo Kosik). Com isso, estudiosos contemporâneos têm-se dedicado a selecionar certos eventos e tentar, a partir daí, apreender seus condicionantes mais amplos, num esforço de compreender o fenômeno em sua totalidade.

Tais condições podem ser identificadas com a práxis dos indivíduos na vida cotidiana, que cria o que Karel Kosik (1976) chama de mundo da pseudoconcreticidade.

"O mundo da pseudo-concreticidade é um claro-escuro de verdade e engano. $\mathrm{O}$ seu elemento próprio é o duplo sentido. O fenômeno indica a essência e, ao mesmo tempo, a esconde. A essência se manifesta no fenômeno, mas só de modo inadequado, parcial, ou apenas sob certos ângulos e aspectos. $O$ fenômeno indica algo que é ele mesmo e vive apenas graças ao seu contrário. A essência se dá imediatamente; é mediata ao fenômeno e, portanto, se manifesta no fenômeno. O fato de se manifestar revela seu movimento e demonstra que a essência não é inerte nem passiva. Justamente por isso o fenômeno revela a essência. A manifestação da essência é precisamente a atividade do fenômeno" (Kosik, 1976:11).

A essência se manifesta no fenômeno de modo parcial ou apenas sob certos aspectos. O fenômeno vive graças à contradição da essência e tal contradição possibilita a investigação científica. Por isso, nesta pesquisa o fenômeno estudado é a gestão escolar, sendo a essência a prática escolar, em mútua determinação contraditória que o real apresenta, e do qual faz parte.

Contudo, de acordo com Cury (1986), os fenômenos não são iguais, e "ao se pretender evidenciar um fenômeno importa estabelecer sua propriedade e especificidade na relação com os outros fenômenos" (p.32). Por isso, importa saber que relações possuem significação essencial para o conhecimento do fenômeno em questão. 
O arcabouço teórico-metodológico selecionado para esta pesquisa, aponta para a necessidade de que o estudo da gestão escolar se faça à luz de uma perspectiva que desvele o concreto (essência/política educacional) a partir do empírico (fenômeno/gestão escolar). Em outras palavras, é preciso conhecer a práxis administrativa existente (empírico/escola gerida) para, com a mediação da teoria (abstrato/análise das propostas de gestão), chegar à práxis administrativa concreta (pensada/ modelos de gestão). Este percurso teórico-metodológico, no qual se parte do empírico, passa-se pelo abstrato e chega-se ao concreto pensado (Saviani, 1989:12), acredita-se adequado para dar conta das questões pertinentes ao estudo aqui realizado.

Uma teoria capaz de iluminar o fenômeno social da gestão escolar e revelar determinantes histórico-sociais tem que ter como pressuposto o movimento, a mudança. Quando se concebe a práxis reflexiva voltada para a transformação social, esta terá como balizamento uma teoria crítica, com a qual manterá uma relação dialética de mútua interferência.

Assume-se, contudo, uma postura dialética, com uma visão dialética do homem e de seu mundo histórico-social, que implica conceber a contradição como um movimento intrínseco numa sociedade composta por classes sociais com interesses antagônicos.

\footnotetext{
"Uma visão dialética do homem e de seu mundo histórico-social implica conceber os dois termos da contradição (indivíduo-sociedade) de modo a rejeitar tanto a concepção que unilateriza a adaptação do indivíduo à realidade do status quo, como a que propõe a realidade como um dado estatístico. Mas, além disso, implica conceber a realidade social como efetivo espaço de luta de classes, no interior da qual se efetua a educação, rejeitando a impositividade da dominação, como o espontaneísmo das classes dominadas" (Cury, 1986:13).
}

Através de um processo dialético, tendo a prática da administração escolar como realidade empírica, poder-se-á construir uma teoria que, ao mesmo tempo, reflita o empírico e o submeta a uma reflexão analítica que desvende suas determinações e evolução histórica.

A superação da fragmentação da realidade empírica exige a apreensão da totalidade (fenômeno mais condicionantes historicamente construídos) e isso só será 
possível através de um procedimento metodológico sensível às manifestações da realidade escolar e a sua contextualização.

A essência do fenômeno (gestão escolar) será reconhecida na articulação dinâmica entre teoria e prática, a fim de que a relação entre elas seja mútua determinação, ou seja, a gestão escolar como expressão de uma práxis administrativa reflexiva.

À medida que se conseguir apreender os condicionantes sociais, políticos e econômicos que configuram os sistemas de ensino, extraindo-se deste contexto social amplo os sentidos e as formas de gestão das escolas que, de alguma forma, estarão sintonizados com os mecanismos mais gerais de produção/reprodução da sociedade capitalista, poder-se-á compreender o fenômeno analisado, seus desdobramentos e impacto na realidade concreta.

Pretendeu-se, num primeiro momento desta pesquisa, sistematizar estudos que avaliem os efeitos das políticas educacionais do Estado do Paraná, a partir de 1988 até 2002. Este período foi escolhido como marco, por ser na Constituição Federal de 1988 que aparece pela primeira vez o princípio da gestão democrática do ensino público. Ele abrange as gestões de Álvaro Dias (1987-1990), de Roberto Requião (1991-1994) e duas gestões de Jaime Lerner (1995-1998 e 1998-2002).

Por tratar-se, hoje, de pesquisa de campo, aparecerá a política educacional do governo atual de Roberto Requião (2003-2006), não se pautando em documentos oficiais, pois ainda estava sendo construída a política educacional da atual Secretaria de Educação (SEED) no período da pesquisa, mas no contexto da realidade concreta das escolas selecionadas. É sobretudo no estudo da política educacional do governo de Jaime Lerner que haverá uma ênfase maior, por ser nos seus oito anos de gestão que se intensificou e solidificou a política educacional neoliberal, proposta pelos organismos internacionais, e a proposta de gestão compartilhada decorrente desta proposta mais ampla de Estado.

Esse momento da pesquisa também consistiu em analisar os documentos estaduais que orientaram uma determinada proposta de gestão escolar e compará-los ou confrontá-los com a prática de gestão em duas escolas públicas estaduais em Londrina. Com isso, pretendeu-se perceber em que medida existe a contribuição da gestão escolar pública para um processo de democratização do ensino público, no 
intuito de conhecer as vias que são utilizadas para sua implementação e sua relação com os modelos de gestão.

Num outro momento, buscou-se compreender o processo de concepção sobre gestão do ensino no interior do Estado e no interior das escolas, ou seja, verificar como as burocracias educacionais, os pais, os professores e demais trabalhadores em educação elaboram suas concepções e as interferências causadas pelas orientações recebidas pela SEED, do ponto de vista histórico e político.

Pretendeu-se, ainda, analisar as práticas de gestão presentes na escola, buscando-se perceber o grau de incorporação, pelas escolas, das políticas de gestão democrática, não só no discurso da comunidade escolar, mas no encaminhamento das ações concretas da escola, no enfrentamento das questões do cotidiano, que revelem o comprometimento da escola com uma determinada concepção de gestão escolar (ou mais de uma), investigando quais as atitudes, comportamentos e atividades da escola que contemplam ou contradizem essa concepção.

Embora a pesquisa de campo esteja situada no governo de Roberto Requião (2003-2006) e a análise teórica abarque principalmente o governo de Jaime Lerner (1995-2002), entende-se que a política educacional imprimida pelo governo Lerner esteja ainda presente nas escolas em razão de sua eficiência nos cursos de capacitação dos profissionais da educação. Portanto, infere-se que, na realidade concreta, nos fenômenos de gestão escolar analisados, encontrar-se-ão essências conceituais tanto da política educacional do governo de Roberto Requião (1991-1994 e 2003-2006) quanto, e principalmente, do governo de Jaime Lerner (1995-2002).

As categorias de análise utilizadas, algumas com dimensão mais ampla e outras com sentido mais restrito, foram democratização do ensino, gestão escolar, descentralização, participação e autonomia. Tais categorias fundamentaram a pesquisa na dimensão teórica fornecendo subsídios históricos, epistemológicos e políticos, e no espaço empírico subsidiaram a busca das contingências que estão presentes concretamente na escola, para posterior imbricamento.

Para Cury (1986), as categorias possuem simultaneamente a função de intérpretes do real e de indicadoras de uma estratégia política. Por isso, ela será utilizada, neste estudo, como instrumento metodológico de análise, ligado à prática educativa e ao contexto de um tempo e um lugar determinados. Para ele “...as 
categorias são conceitos básicos que pretendem refletir os aspectos gerais e essenciais do real, suas conexões e relações" (Cury, 1986:21).

Para tanto, foram selecionadas duas escolas estaduais em Londrina-PR. A escolha das escolas pautou-se pela localização da escola (central e periférica); pelo lugar que a escola ocupava no ranking que classificava as "Escolas de Excelência" do Paraná e pelo perfil do diretor.

Quanto ao último critério pode-se fazer algumas considerções que justificam a opção por tal critério. Uma das escolas tem um diretor que se inclina para uma postura crítica diante do modelo neoliberal proposto pela Secretaria Estadual de Educação do Paraná (SEED-PR) e a outra escola possui um diretor que, pelo menos a priori, adere a esse modelo passivamente.O diretor tornou-se figura fundamental na gestão escolar e no contexto das reformas na política educacional do Paraná, sendo depositada nele a responsabilidade de operacionalização das medidas e dos mecanismos do modelo de gestão congruente com a Gerência da Qualidade Total (GQT). Esta ênfase na figura do diretor expressa a visão autoritária que se pode observar na formação dos diretores e integrantes das APMs e Conselhos Escolares que se intalou na gestão do governador Jaime Lerner.

Os diretores de escolas estaduais, sob pressão da estrutura burocrática da máquina governamental _ posto que é sobre os aspectos formais do funcionamento das escolas que eles são cobrados e avaliados _ têm sua atuação reduzida e limitada às determinações burocrático-administrativas, em detrimento do aspecto político que pressupõe sua atuação. Entende-se a atuação do diretor no seu aspecto político quando busca a horizontalidade das relações de poder no interior da escola, cria as condições propícias à tomada de decisões coletivas e define estratégias de pressão sobre o governo para defender os interesses da comunidade atendida.

Para isso, foi feito o acompanhamento da realidade concreta que permitiu conhecer os conteúdos políticos que foram desenvolvidos nas práticas pedagógicas e administrativas das escolas selecionadas e identificar como se constituiu a hegemonia nos procedimentos administrativos e pedagógicos das escolas.

Além disso, foram feitas observações e entrevistas nas escolas com uma amostra ${ }^{4}$ dos principais representantes da comunidade escolar. Um dos caminhos que se considerou preliminarmente adequado e válido para o conhecimento de realidades 
restritas, a observação dos sujeitos das escolas selecionadas para a pesquisa de campo, serviu como instrumento para desvelar os processos sociais.

Quando se fala em amostra, pode-se pensar que não seja uma alternativa que dê conta de apreender a totalidade.

"Por menor que seja a representatividade de um indivíduo em relação ao
conjunto, o importante é que ele valha pela sua 'exemplaridade'. O fato de, no
caso em estudo, encontrar-se presente determinado fenômeno ou particularidade
do real, não significa que tal ocorrência seja generalizada; nem se trata de prová-
lo. Trata-se, isto sim, de procurar a 'explicação' adequada para tal ocorrência, o
que nos permitirá dizer apenas que, em acontecendo tal fenômeno, sua
explicação é a que oferecemos ou na qual apostamos" (Paro, 1995:28).

As entrevistas semi-estruturadas foram feitas com a direção, com a equipe técnico-pedagógica, com um representante dos professores do Conselho Escolar (CE), com um representante dos funcionários no $C E$, com o presidente do CE e com o presidente da APM. Foi elaborado um roteiro de entrevista, não pela necessidade de ter uma direção única e inflexível, mas para ter uma linha de raciocínio consciente e articulado com as categorias de análise selecionadas.

A dinâmica das entrevistas variava de entrevistado para entrevistado, permitindo muitas comparações tanto entre as escolas, quanto entre os sujeitos de uma mesma escola.

No decorrer das entrevistas houve a necessidade de fazer ajustes na forma de perguntar e na forma de explorar uma determinada categoria de análise, dependendo do nível de compreensão do entrevistado. Isso foi sendo percebido à medida que se foi estabelecendo uma relação de diálogo entre entrevistador e entrevistado.

O conceito de gestão democrática da escola, tendo como estratégia a politização da educação e da gestão escolar, iniciada no período da chamada transição democrática, passará pela análise em dois planos:

a) como tal proposta evoluiu, foi elaborada, modificada, assimilada, reelaborada e ressignificada no nível da política educacional do Paraná tendo centralidade na gestão;

b) como tal proposta evoluiu, foi elaborada, modificada, assimilada, reelaborada e ressignificada no nível das escolas.

Tem-se, além disso, a consciência da contradição como princípio explicativo do real, pois "pela reflexão, a natureza dialética do real encontra, na consciência da 
contradição, sua expressão subjetiva, e também a possibilidade de uma interferência no real" (Cury, 1986:32).

Com estes dados e informações será feita uma tentativa de explicação de como estes dois planos se relacionam sem se cair numa visão mecânica, mas tendo-se claro que em cada um destes planos há contradições. Mesmo as explicações ensaiadas nesta pesquisa não estão isentas de contradição, considerando-se que o pesquisador é um sujeito histórico com seus anseios, necessidades e dificuldades; mas que está buscando refletir sobre o fenômeno da gestão escolar, tentando percebe-lo e relacionalo com suas essências conceituais e ideológicas. 


\section{A ADMINISTRAÇÃO ESCOLAR E OS SEUS ELEMENTOS HISTÓRICOS}

Segundo José Querino Ribeiro, no Brasil, a expressão administração escolar aparece pela primeira vez em 1883 nos pareceres e projetos de Ruy Barbosa, ao analisar aspectos diversos da administração do sistema escolar vigente. Porém, após 40 anos é que surge o Manifesto dos Pioneiros da Educação Nova em 1932, que irá aprofundar-se mais sobre a administração escolar. Também irão inseri-la no currículo pedagógico do Instituto de Educação do Rio de Janeiro, quando se dará a reforma do ensino feita pelo professor Anísio Teixeira. Em São Paulo, a Administração Escolar entra no rol das disciplinas no curso de formação de diretores e inspetores escolares do ensino primário. Em 1939, ao se criar a Universidade do Brasil, incluiu-se entre as cadeiras do Curso de Pedagogia, na Faculdade de Filosofia, a cadeira de Administração Escolar, a qual fica associada à de Educação Comparada.

Além disso, tal contexto agrega fatores históricos determinantes da educação e da sua administração, como a pouca valorização da educação pelos governantes, a ação quase que exclusiva da Igreja Católica na organização da educação e a influência do positivismo no pensamento político.

De acordo com o autor, o Estado, inserido nesse contexto de mudanças, ciente e seguro das vantagens usufruídas ao longo do tempo, envolve a escola na sua hipertrofia, estatizando a educação de forma centralizada. O autor discorre sobre alguns princípios fundamentais da educação que nortearam estudos e práticas da administração escolar: o da liberdade, o da responsabilidade, o da unidade, o da economia e o da flexibilidade. Já nesse período podemos identificar a sempre forte e presente proposta de administração escolar enveredada na busca da eficiência e da produtividade.

Lourenço Filho (1976), em sua obra "Organização e administração escolar", desenvolve um estudo pioneiro da temática abordada nesta pesquisa, no qual encontramos elementos já ultrapassados e outros significativos para os dias atuais que, inclusive, influenciaram diversos estudos. Num primeiro momento, o autor caracteriza as realidades de estrutura e gestão dos serviços escolares, confrontando as teorias gerais de organização e administração clássicas e consideradas recentes para o determinado contexto. Estuda o processo e o comportamento administrativo, ou seja, $o$ que fazem os administradores, como fazem e por que fazem. Analisa também as 
relações entre os serviços escolares, a economia e as finanças, disso retirando os fundamentos de planejamento e controle; preocupações estas que marcam os estudos da época.

O autor inicia seus estudos demonstrando a intrínseca relação entre a prática administrativa e seus elementos constitutivos com a razão primeira da administração escolar que é a educação escolar mais unificada com a vida social, representando as dimensões de desenvolvimento individual, por um lado, e de ajustamento social, por outro.

Para ele, "os problemas de organização e administração escolar terão de ser nessa fase compreendidos, analisados e resolvidos, e, pois, com maior sentido de previsão. Terão eles que ser propostos no conhecimento das realidades sociais em mudança, e reinterpretados à luz de uma nova política de educação, que não caberá aos administradores escolares por si mesmos elaborar, é certo, mas bem traduzir em realidades práticas, de satisfatória eficiência" (FILHO, 1976:21).

Já nesse período percebe-se a preocupação em atentar os administradores escolares para o relacionamento entre os objetivos, que não podem deixar sobrepor o aspecto burocrático-administrativo sobre os fins educacionais a longo prazo, e os meios para alcançar tais fins, pois tais objetivos significativos "só aparecem num dado conjunto funcional, numa certa estrutura, já entendida como destinada a alcançar determinados objetivos, previamente aceitos, e de obtenção possível segundo os elementos e condições existentes". (FILHO, 1976:25)

Nesse período, os autores brasileiros tinham à disposição apenas bibliografia norte-americana, de onde se extraíram conceitos, vertentes, classificações e metodologias de estudos sobre administração escolar, alguns dos quais perduram até os dias atuais. A utilização da teoria geral da administração começa a ser utilizada como referencial para a teorização da administração escolar.

As perspectivas de estudo de administração escolar encontradas em Lourenço Filho são a histórica, a comparativa e a de eficiência. Na "perspectiva histórica" considera que a realidade é derivada e nutrida pelas condições de um amplo processo, do qual não pode ser separada. Podemos entender, então, como um

"Processo educacional, compreensivo de todas as formas pelas quais as
gerações mais amadurecidas influam nas que menos o sejam, com a
comunicação de seus modos de fazer, sentir e pensar, ou, em termos mais
precisos, a comunicação de técnicas, idéias, sentimentos e aspirações" (p.29).

A "perspectiva comparativa" estabelece a pesquisa das "razões da articulação geral ou dos fatores determinantes da existência das instituições escolares, na forma de 
sistemas de ensino de cada povo ou de cada nação, numa dada época. Mediante confronto entre condições e resultados, em diversos meios, caracterizam-se varáveis, e retiram-se inferências de ordem geral' (FILHO, 1976:29). Além disso, fala-se de "estruturas e funções gerais dos sistemas nacionais de ensino, segundo aspectos que se tipificam a cada época, à vista de condições gerais, conjugadas por ação política" (p.30).

Essa comparação entre realidades distintas, com características e necessidades próprias deve subsidiar, segundo o autor, a elaboração de estratégias eficientes, com maior domínio da ação intencional da educação. É por isso que ressalta a necessidade de um planejamento de ação, além da coordenação dos elementos constitutivos, "numa execução de tarefas que se aprimore pela experiência, e cujo rendimento possa ser, enfim, avaliado mediante critérios objetivos, de maior sentido técnico". (p. 30)

Nessa perspectiva (comparativa), percebe-se a ênfase no âmbito técnico em detrimento de outros âmbitos, muito embora a perspectiva histórica ressaltada pelo autor seja um elemento que propicia considerar a totalidade dos fenômenos que interferem, direta ou indiretamente, na prática administrativa. A conseqüência das perspectivas anteriores explicitadas, segundo o autor, seria uma maior eficiência. Para tanto, conceitua a

"perspectiva de eficiência" que "supõe a gradação de objetivos definidos, segundo a compreensão das funções sociais que a escola deva atender; mas, assim também de boa coordenação dos elementos e dos recursos que representem meios idôneos para a consecução dos fins propostos, na forma de implementos técnicos e satisfatórios" (p.31).

Embora, na perspectiva histórica proposta pelo autor, seja possível considerar um avanço conceitual o qual terá impacto nos estudos sobre gestão escolar, percebese, nas perspectivas comparativa e de eficiência, a influência do modelo fordista de produção sob a égide gerencial que, nos dias atuais, com roupagem e mecanismos renovados, está subsidiando as reformas educacionais emanadas pelo Estado.

No contexto em que Lourenço Filho desenvolveu seus estudos, houve um movimento construído contraditoriamente, visto que, sendo a demanda a impulsionadora da produção industrial, o progresso técnico não a acompanhou, mesmo que as teorias clássicas de administração tenham valorizado tanto o aspecto técnico em detrimento do político.

Nesse contexto, o fato de o avanço técnico-científico não se constituir a mola propulsora da modernização, ele se refletiu nas formas de tratamento da questão 
educacional. Além disso, forjou-se um pacto de poder que permitiu a continuidade das antigas estruturas de dominação.

Encontramos em Benno Sander (1982) uma revisão histórica para o conhecimento da administração da educação no Brasil no contexto evolutivo do desenvolvimento teórico da administração pública brasileira (p.5), segundo quatro enfoques: jurídico, organizacional, comportamental e sociológico. Tais enfoques não ocorrem de maneira isolada, adverte o autor, porquanto há entre essas fases uma superposição.

Para o autor, ao longo da história, que se estende pelos períodos colonial, imperial e da primeira República, houve o predomínio absoluto do "enfoque jurídico, essencialmente normativo e estreitamente vinculado à tradição do direito administrativo romano" (p.12-13). Essa tradição, segundo o autor, propiciou as condições para a adoção "da cultura e dos princípios de administração da educação desenvolvidos nos países da Europa continental” (p.12), cujo traço marcante é o legalismo, ou seja, a lei que, antecipando-se aos fatos sociais, torna-se o ideal a ser atingido.

O autor assinala a década de 30 como o início das contribuições que ele classifica como "enfoque organizacional'. Ocorre a extensão dos princípios da teoria clássica da administração ao espaço educacional, fase que ganha vez com o Estado tecnocrático que se instalou após a revolução de 1930.

Algumas características importantes da teoria clássica são elucidativas da sua inadequação como fundamento para a administração educacional: sua excessiva ênfase nos aspectos da estrutura e processos organizacionais e sua omissão dos fatores políticos, econômicos e culturais que intervêm nesses processos. Tais características revestidas da ideologia neoliberal, parecem nortear as políticas públicas para a gestão escolar nos dias atuais.

Anísio Teixeira, José Querino Ribeiro, Antônio Carneiro Leão são os pioneiros do "enfoque organizacional" na administração escolar, segundo Sander.

Para José Querino Ribeiro (1978), as atividades da administração escolar são: "planejamento, organização, assistência à execução ou gerência, avaliação de resultados, prestação de contas ou relatório" (p.119). Sua inspiração fayolista revela-se quando define a administração escolar como

“... um complexo de processos técnicos, cientificamente determináveis que, servindo a certa filosofia e certa política de educação em geral, e de escolarização em particular, desenvolve-se antes, durante e depois das 
atividades básicas da escola, com o objetivo de assegurar-Ihe unidade, economia e aperfeiçoamento" (p.179).

A conceituação aceita pelos participantes do I Simpósio Brasileiro de Administração Escolar, realizado em São Paulo, em 1961, corrobora de forma eloqüente, a tese de que até então a administração escolar era encarada como extensão da teoria geral da administração.

"A administração escolar supõe uma filosofia e uma política diretoras préestabelecidas; consiste no complexo de processos criadores de condições adequadas às atividades dos grupos que operam na escola em divisão de trabalho; visa à unidade e economia de ação, bem como o progresso do empreendimento. O complexo de processos engloba atividades específicas planejamento, organização, assistência à execução (gerência), avaliação de resultados (medidas), prestação de contas (relatório) - e se aplica a todos setores da empresa - pessoal, material, serviços e financiamento" (Relatório de I Simpósio Brasileiro de Administração Escolar, apud Sander, 1982:18).

Com a substituição da influência econômica e cultural européia pela americana, acelerada após a Segunda Guerra Mundial, observa-se, também na administração da educação, uma crescente influência da produção teórica norte-americana. Assim é que, acompanhando o movimento renovador da teoria geral da administração que lança críticas contra a teoria clássica e incorpora à teoria administrativa o conhecimento das ciências do comportamento, entre as quais Psicologia e Sociologia, surge o que Sander classifica como "enfoque comportamental" para designar um conjunto de idéias que pretende explicar o comportamento administrativo.

Essa fase comportamental, ainda que crítica em relação à teoria clássica, não abandona de todo o caráter prescritivo da administração. Apesar de inspirar muitos trabalhos, o "enfoque comportamental" não se estabeleceu como base teórica para um modelo de administração escolar.

É com a adoção de variáveis políticas, sociológicas e antropológicas nos estudos de administração pública e da educação, no Brasil, que Sander identifica o início de um movimento ao qual denomina "enfoque sociológico". A preocupação com a "utilização de quadros de referência concebidos nos limites impostos pela realidade brasileira" é uma característica dos estudos realizados sob esse enfoque como tentativa de superar os problemas impostos pelo contexto sociopolítico à aplicação dos princípios dos enfoques anteriores (Sander, 1982:21-22).

Tal enfoque tem caráter interdisciplinar e contextual, ou seja, com ele busca-se compreender o fenômeno educativo e sua administração enquanto parte do todo social 
e seus múltiplos aspectos, superando a visão até então dominante e insuficiente da educação enquanto processo restrito e particular, independente do social.

Nesse contexto, a forma cooperativa de atendimento das demandas do trabalho, a legislação sindical, a instauração da ditadura do Estado Novo, as práticas de cooptação, a vigência restrita da democracia política no pós-guerra, a predominância das práticas populistas no processo de incorporação das massas, o golpe militar de 1964 são fenômenos denunciadores do caráter autoritário desse sistema de dominação que influenciaram o processo de construção de identidade(s) para a teoria de administração escolar.

Interessa também destacar que o crescimento urbano, intensificado pelo processo de industrialização e de suas conseqüências, acarretou pressões responsáveis pela ampliação de oportunidades educacionais. Criou-se, assim, uma demanda social por educação que acabou resultando numa considerável expansão da oferta de ensino e no aumento dos níveis de escolarização.

Com isso, proporcionalmente à ampliação das oportunidades escolares ${ }^{5}$ crescem as inquietações, estudos e capacitações convergentes à administração escolar.

Percebe-se o quanto as influências das esferas política, econômica e social incidem intensamente na teoria e prática da administração escolar, sendo possível vislumbrar que, por conseqüência de tais influências, que se relacionam contraditoriamente na sociedade capitalista, a administração escolar possui caráter autoritário, clientelista, com relações de poder verticalizadas, com atributos tecnicistas, tendo como referência a lógica empresarial. Com isso, forja-se o aspecto político da educação, através do solapamento dos canais decisórios coletivos. Miguel Gonzalez Arroyo (1983) destaca os "aspectos políticos da administração da educação, cujo critério definidor é a efetividade no atendimento das necessidades sociais da comunidade".

A partir da década de 70 , observa-se uma alteração na trajetória da teoria pedagógica que vai incidir na administração escolar, inicialmente com base na concepção crítico-reprodutivista e, em seguida, crítico-transformadora.

\footnotetext{
${ }^{5}$ É importante destacar que esse aumento das oportunidades educacionais está contextualizado numa dinâmica política populista, na qual o Estado capitalista se vê obrigado a atender reivindicações das massas trabalhadoras para obter legitimidade.
} 
Ao final da década de 1970, quando se processa uma alteração da teoria pedagógica, deflagra-se uma forte crítica ao regime militar e à sua política educacional. Razoável parcela dos educadores não aceita a educação tecnicista inspirada na teoria do capital humano e baseada nas idéias de racionalidade, eficiência e produtividade, imposta pelo governo autoritário e tecnocrático.

É interessante notar que mais tarde tais idéias serão apropriadas pelo neoliberalismo, que as anuncia como inovadoras, muito embora se possa perceber que existe apenas a ressignificação de tais idéias para, com isso, forjar o consenso acerca de suas estratégias utilizadas. As origens do corolário ideológico empresarial estão em Ford, Taylor, Fayol, entre outros teóricos da administração clássica geral e, conseqüentemente, na administração escolar.

A abertura política que culminou com a eleição direta dos governadores de Estado em 1982, vencida em muitos deles por candidatos da oposição, permitiu que alguns projetos de reforma educacional democratizantes fossem implementados em alguns estados, abrindo-se campo não somente para a discussão das teorias críticas da educação como também, em alguns casos, para a sua testagem prática. Nesse contexto, a administração escolar sofre severas críticas, por autores como Félix, Arroyo e Paro, que, mesmo fazendo parte de um período em que houve avanços, principalmente quantitativos, no setor educacional, irão contribuir para a elaboração de uma proposta de administração escolar articulada com a tendência pedagógica progressista, que possui como categorias de análise a relação de dominação e a luta entre classes sociais antagônicas.

As tendências pedagógicas progressistas têm em comum o projeto de superação da sociedade de classes. Ainda que se fundamentem em pressupostos teórico-doutrinários diferentes, a educação é para elas um relevante componente transformador da sociedade. Suas propostas metodológicas apresentam concepções semelhantes sobre as funções estratégicas exercidas pela educação na transformação social. Em todas elas, a democratização dentro da educação e das relações de poder dentro da escola é uma constante.

Um estudo sobre a administração da educação que pode ser considerado como um marco da visão crítico-transformadora é o, já citado, de Miguel Gonzalez Arroyo (1983). 
Com o propósito de proceder a uma reflexão sobre as dimensões políticas das tendências da administração da educação no Brasil, o autor faz detalhada análise das políticas educacionais dominantes na década de 70, baseadas na teoria do capital humano, de eficiência, racionalidade e produtividade. Segundo o autor, a política educacional, naquele período, atribui à irracionalidade administrativa a responsabilidade pelo baixo desempenho do sistema escolar. Com essa perspectiva, a política educacional colocava a modernização administrativa como estratégia para a melhoria da educação, desviando assim a atenção das determinantes da educação.

A racionalidade administrativa pretendida para o sistema escolar oculta a dimensão política do processo administrativo e não questiona a irracionalidade da sociedade e da economia. A distribuição desigual da educação em uma sociedade desigual é, na verdade, uma manifestação de racionalidade, segundo o autor.

O discurso da modernização e racionalização do ensino, através da administração, é um argumento que visa mascarar o objetivo real de adequar a educação às necessidades do capital. As teorias e práticas administrativas têm desempenhado um importante papel político na percepção do antagonismo entre capital e trabalho. Nas palavras do autor, "controlando-o, amortecendo-o, diluindo-o ou justificando-o" (p.40). As teorias e práticas da administração têm sua história vinculada ao modo de produção capitalista e têm sido utilizadas como mecanismos de controle e hierarquização do trabalho para garantir maior produtividade e acumulação, exercendo um papel essencialmente político.

Se, na década de 1970, a eficiência do sistema era cobrada com base nas políticas do Estado intervencionista e parceiro dos interesses do capital, a partir de década de 80 , os argumentos voltam-se para a necessidade de competitividade e qualidade para uma economia de mercado mundial. Com isso, gradativamente vão-se construindo mecanismos que garantem a lógica mercadológica em todos os âmbitos da sociedade, inclusive na educação e na administração escolar.

Nesse sentido, Maria de Fátima Félix (1989) realiza um importante estudo sobre a relação entre administração empresarial e administração escolar.

A autora situa a estruturação do sistema escolar no contexto do desenvolvimento do capitalismo no Brasil. Sua análise é pautada nas reformas do ensino superior (lei $5540 / 68$ ) e do ensino fundamental e médio, antigos $1^{\circ}$. e $2^{\circ}$. graus (lei 5692/71), ambas formuladas no período do regime militar, quando se instaurou uma forma de Estado 
autoritário e intervencionista, cuja meta era consolidar um projeto de desenvolvimento, que internacionalizava a economia nacional por meio da burocratização do Estado como forma de controle.

A autora destaca as preocupações, na política educacional do período, com o aprimoramento técnico, com a eficiência e produtividade da escola, consubstanciadas no privilegiamento dos cursos técnicos superiores e médios e na articulação do sistema escolar com o mercado de trabalho, sempre com o objetivo de "adequar a escola ao desenvolvimento do capitalismo na sua etapa atual" (p.31). Para a autora, as reformas

"consumaram ao nível legal um processo de intervenção da estrutura econômica na redefinição das instituições culturais do país" (p.31).

Num segundo momento do seu estudo, Félix evidencia a relação entre administração escolar e empresarial. Apoiada na análise dos vários movimentos que vêm sucedendo na composição da teoria geral da administração, a autora revela a subordinação da administração aos interesses do capitalismo, porquanto teoricamente desempenha papel ideológico na atenuação ou negação dos conflitos fundamentais decorrentes das relações sociais nesse modo de produção.

Para Félix (1989), "a administração escolar não construiu um corpo teórico próprio e no seu conteúdo podem ser identificadas as diferentes escolas da administração de empresa, o que significa uma aplicação dessas teorias a uma atividade específica, neste caso, à educação" (p. 17).

A assimilação da administração empresarial pela escolar decorre, segundo a autora, de dois pressupostos: 1) os modelos de estrutura e de processos desenvolvidos pelas teorias da administração de empresas são aplicáveis a qualquer tipo de organização, independentemente de seus objetivos, bastando apenas adaptar os princípios administrativos às metas específicas de cada organização_essa posição aparece na literatura da administração geral; 2) a escola somente será capaz de atender às exigências que a sociedade lhe faz quando se organizar segundo os preceitos da teoria da administração de empresas, isto é, quando utilizar métodos e técnicas administrativas que garantam eficiência às suas ações. Essa é a perspectiva dominante dos teóricos brasileiros da administração escolar do período anterior ao final da década de 1970, entre os quais Félix cita Ribeiro (1978) e Alonso (1976).

Da análise de Félix, fica claro que a assimilação da administração empresarial pela escolar não se dá somente na teoria, mas também na prática, quando a escola adota os modelos de estrutura e funcionamento de empresa. 
A generalidade do conhecimento administrativo compreenderia um conjunto abstrato de conceitos que poderia ser aplicável a qualquer tipo de organização. Seria um conhecimento a-histórico. Não é essa, no entanto, a natureza do conhecimento administrativo, já que a teoria da administração está historicamente ligada ao desenvolvimento do capitalismo e por este determinada.

Quando torna seus os fundamentos da teoria geral da administração, a administração escolar está contribuindo para reforçar ainda mais as funções ideológicas da educação, pois no capitalismo as teorias da administração são instrumento de legitimação de um "modus operandl" que adota a eficiência, a racionalização e a produtividade como critério de referência para todas as organizações. É o resultado da expansão do capitalismo para áreas que extrapolam a produção material, visando à exploração de todas as atividades que possam produzir mais-valia.

Tal discurso está claro e explicitamente assumido nas propostas de reforma da educação de inspiração neoliberal e tem sua máxima na proposta de administração para a "Gerência Qualidade Totap" como fundamento para a administração escolar.

Nos últimos parágrafos da sua conclusão, a autora assinala:

“... a educação contém em si a unidade dialética da reprodução e da transformação que resulta do movimento contraditório presente na sociedade de classe" (p.193). E propõe como questão a ser estudada "a da utilização da administração escolar no processo de organização da escola como um momento de hegemonia" (194).

A superação do quadro de sobreposição da teoria geral da administração à teoria educacional, apontado pela autora, requer que a teoria de administração escolar, numa primeira ruptura com a teoria geral da administração, assuma a especificidade das suas práticas, a dimensão política da sua ação e a sua historicidade. Somente, assim, a escola e a educação, poderão desempenhar uma função de desmistificadora do discurso ideológico para transformadora da sociedade.

Para Vitor Paro (1986), é necessário que a administração escolar assuma uma função crítica. Para isso terá que tomar como ponto de partida a especificidade e natureza dialética da educação e sua relação com a totalidade das relações sociais, entendendo a administração como ação política e não como técnica neutra e autônoma.

A organização empresarial capitalista com sua lógica de expansão ampliada do capital tem como fundamentos a racionalidade funcional, a objetividade, a hierarquia e

\footnotetext{
${ }^{6}$ Em outro momento deste trabalho discutir-se-ão as características do modelo de Gerência da Qualidade Total e seu implante na política e gestão educacionais.
} 
como condição necessária à exploração do trabalho; a impessoalidade. O processo educativo, ao contrário, fundamenta-se na solidariedade e igualdade entre os homens; é um processo humano voltado para a promoção do indivíduo e do coletivo; sua lógica se distancia daquela da empresa. Diferem, assim, os problemas das organizações escolar e empresarial, invalidando a aplicação dos princípios de administração desta última à primeira.

Faz-se necessário abandonar a visão da administração escolar como prática autônoma, adotando-se uma perspectiva de ação político-educativa que se volte para a organização do trabalho coletivo na escola, levando-se em conta a natureza do processo pedagógico e sua função social.

Para Paro (1986), há uma forte tendência do regime capitalista em aplicar a todas as instituições, em especial às educativas, os mesmos princípios e métodos administrativos vigentes na iniciativa privada. $O$ autor esclarece que toda administração tem como "essencial" o fato de ser ela a utilização racional de recursos para a realização de fins determinados, sendo estes fins buscados que darão especificidade a cada administração em particular, esclarece também que a administração capitalista, concebida para dar conta dos problemas relacionados à eficiência interna e ao controle do trabalho alheio na empresa produtora de bens ou serviços, tendo como escopo servir à apropriação do excedente, pela dominação do trabalhador, torna-se imprópria a sua aplicação em instituição cujos fins é a constituição de sujeitos e não de produtos.

Também Hidalgo (2001) fala da inconsistência da aplicação do modelo de gestão empresarial nas instituições escolares, por envolver seres humanos, fala também das diferenças de objetivos a serem atingidos, fazendo inúmeras críticas contra a aplicação da "Gerência da Qualidade Total" na educação pela divergência de objetivos, pela necessária alienação de seus partícipes e pela visão reducionista de educação que é considerada apenas pelo aspecto econômico. 


\subsection{ADMINISTRAÇÃO ESCOLAR E GESTÃO DEMOCRÁTICA DA ESCOLA: ASPECTOS CONCEITUAIS E IDEOLÓGICOS}

O termo administração é substituído pelo termo gestão, no bojo dos movimentos de democratização da sociedade, a partir do final da década de 70 .

Já na década de 80 , a bandeira histórica de luta dos setores da área educacional que pretendiam mudanças profundas na organização educativa, defendendo a democratização do ensino, começa a ser apropriada pelos projetos de reforma empreendidos pelos governos de cunho neoliberal, mas é na década de 90 que tal reforma é intensificada.

Na década de 80, momento histórico que teve avanços no que diz respeito ao processo de democratização da sociedade, criaram-se instâncias democratizadoras como colegiados, conselhos e comissões que tinham e têm a função de acompanhar e controlar determinadas demandas. Configurou-se, de acordo com Camargo (1997), um "clima" de maior participação e tomada de decisão mais coletiva em toda a sociedade brasileira. Diversas investidas legais foram realizadas (poder executivo e legislativo) procurando estabelecer, em texto legal, iniciativas democratizadoras.

De acordo com Rubens Barbosa de Camargo (1997), qualquer processo legislativo carrega, em sua essência, deferentes interesses em jogo, muitas vezes antagônicos, em razão das quais, na maioria das vezes, a lei expressa a síntese de um processo conflitivo. O princípio da gestão democrática e seu "aparecimento" no texto constitucional ocorreram com conflitos carecendo de definições mais precisas. Entre outras disputas políticas sociais e econômicas no processo constituinte, e de intenso processo de participação, a discussão acerca da gestão democrática suscitou interesses conflituosos, apontando, porém, perspectivas interessantes do ponto de vista da democracia participativa. Ao final, o conceito de gestão definido constitucionalmente agregou o termo "no ensino público", na forma de lei, o que se constituiu uma vitória dos setores privatistas, levando a uma solução pasteurizada das questões a esse respeito, pois remeteu à nova LDB a regulamentação desse princípio.

Tais reformas tiveram, como um dos principais eixos, a alteração na gestão e organização da educação. Nesse contexto é que a expressão "gestão democrática 
da educação" emerge defendendo mecanismos mais coletivos e participativos no âmbito da gestão escolar.

Os termos gestão e administração são tratados por Paro (2000) como sinônimos, quando afirma que o que os especifica é o seu caráter de mediadores da concretização de um fim, uma vez que, ao se administrar ou ao se gerir, utilizam-se recursos da forma mais adequada possível para a realização dos objetivos-fins. Também nos diz que o papel da gestão escolar está intimamente ligado à democracia, pois, entre outros benefícios, podem proporcionar a aquisição de valores e recursos democráticos propiciadores da convivência pacífica entre os homens em sociedade.

Outro entendimento, que não dispensa os anteriores, é considerar gestão escolar como processo político-administrativo contextualizado. Algumas vezes a gestão é apresentada como processo dentro da ação administrativa; outras vezes seu uso denota apenas intenção de politizar a ação administrativa; noutras apresenta-se como sinônimo de gerência, e, em muitos momentos, a gestão aparece como nova alternativa para o processo político-administrativo da educação.

\footnotetext{
"Uma opção interpretativa apregoa que a substituição sugere uma tentativa de superação do caráter técnico, pautado na hierarquização e no controle do trabalho por meio da gerência científica, que a palavra administração (como sinônimo de direção) continha. Neste caso, sua substituição pelo termo gestão pode significar a adoção de uma nova lógica na organização do trabalho, cujo pressuposto seria evidenciar os aspectos políticos inerentes aos processos decisórios" (Camargo e Adrião, 2001:75).
}

Contudo, a terminologia altera-se a cada momento histórico, dependendo dos interesses da classe dominante e da tendência político-econômica que apostam que a alteração dos termos expresse alteração dos pressupostos teórico-metodológicos e ideológicos. Assim, a expressão administração escolar, utilizada nas décadas anteriores a 80, está impregnada de pressupostos primordialmente técnico-burocráticos e legalistas, sendo preciso, portanto, sua substituição pelo sintagma gestão escolar que, subentende-se como resgate do aspecto político dessa prática. Além disso, a gestão escolar é colocada numa posição privilegiada no aglomerado de estratégias neoliberais, ressignificando-a com caráter fetichizado, diante de seu potencial mercadológico, obscurecedor das verdadeiras relações sociais intrinsecamente capitalistas. Essa ressignificação, longe de perder seu sentido técnico e racional, embora anuncie o resgate do caráter político da administração escolar, carrega a lógica da "Gerência de 
Qualidade Total'. A esta ressignificação da administração escolar denomina-se "gestão democrática".

A expressão "gestão democrática" como princípio e de suas acepções possuem explicação histórica. No processo de elaboração da Constituição Federal de 1988 , momento em que o povo lutava por uma sociedade democrática, os grupos organizados da sociedade civil pressionaram os constituintes para inscreverem na Carta Magna o princípio da gestão democrática do ensino, na tentativa de construir uma escola fundada em preceitos democráticos, "que desmanchasse a atual estrutura hierarquizada e autoritária que inibe o exercício das relações verdadeiramente pedagógicas, intrinsecamente opostas às relações de mando e submissão que são admitidas, hoje, nas escolas" (PARO, 2001:81).

Entretanto, a lei apresenta limites de operacionalização quando omite a definição de diretrizes gerais para a constituição e gestão dos diferentes sistemas de ensino. Com isso, tem-se como resultado pouco ou nenhum avanço "no sentido da constituição de mecanismos reais de participação de trabalhadores em educação e usuários das redes públicas em instâncias decisórias dos sistemas de ensino" (ADRIÃO e CAMARGO, 2001:78).

Aliás, os esforços dos grupos hegemônicos concentram-se não mais no modelo legalista burocrático, nem no modelo democrático participativo, no qual as relações de poder são horizontalizadas, constituindo-se o envolvimento da comunidade nos processos deliberativo uma prática coletiva nos âmbitos administrativos e pedagógicos; mas utilizam uma mescla de estratégias de ambas acepções, classificando (e ressignificando) as que melhor lhes convêm para a perpetuação das relações de dominação na sociedade capitalista. 


\subsection{A APROPRIAÇÃO DO PARADIGMA DA “QUALIDADE TOTAL” PELA GESTÃO ESCOLAR E A FETICHIZAÇÃO DA EDUCAÇÃO}

E possível notar como ainda não foi superada a estratégia de adaptação da teoria geral de administração para a administração escolar e para a educação, ou da economia (como é o caso da Teoria do Capital Humano) para a educação. No contexto de reforma da educação pública, a gestão escolar, enquanto eixo de tal reforma, recebe ressignificação consubstanciada, novamente, na teoria geral de administração.

É o adentramento dos "Programas de Qualidade Total" na educação e na gestão escolar. Essa teoria considerada uma revolução na administração, cujo principal representante é W. Edward Deming, tem por objetivo tornar a economia mais competitiva, produtiva e lucrativa.

Sônia Laranjeira (1997) afirma que os Programas de Qualidade Total (PQT) estão associados aos modos pós-fordistas de organização do trabalho que favorecem a participação dos trabalhadores ${ }^{7}$ nos processos de tomada de decisão nas empresas, "contribuindo para a emergência de uma suposta democracia industrial" (Laranjeira, 1997:184). Nesse sentido, apregoa-se a necessidade de redução dos níveis hierárquicos e de descentralização e de autogerenciamento de departamentos, a delegação de tarefas, o compartilhamento de responsabilidades e a circulação de informações. Paro (1986) nos esclarece que tal "valorização" dos trabalhadores, através de sua participação na instituição, não possuindo caráter humanístico, acaba por encobrir o caráter social do trabalho, apresentando-se como relações justas entre proprietários de mercadorias e impedindo que se perceba a exploração do trabalho presente nessas relações.

A autora nos apresenta os princípios norteadores do PQT formulados por Deming: 1) constância de propósito; 2) adoção da nova filosofia; 3) introdução da qualidade desde o primeiro estágio do produto; 4) fidelidade ao fornecedor; 5) melhoria constante do processo de produção ou da prestação de serviço; 6) treinamento no local de trabalho; 7) instituição da liderança; 8) eliminação do medo; 9) eliminação de barreiras; 10) eliminação de lemas, exortações e metas para os trabalhadores; 11)

\footnotetext{
${ }^{7}$ Num primeiro momento, quando o Estado, ou outras instituições com características capitalistas, anuncia a defesa da participação dos trabalhadores em processos decisórios, a impressão que se tem é que está impregnado de preceitos democratizantes. Entretanto, "a súbita redescoberta e valorização da dimensão humana do trabalhador está muito mais afeta a sinais de limites, problemas e contradições do capital na busca de redefenir um novo padrão de acumulação com a crise de organização e regulação fordista, do que a autonegação da forma capitalista de relação humana” (Frigoto, 1994:41).
} 
eliminação da administração por objetivos; 12) garantia de que o trabalhador possa orgulhar-se de seu trabalho; 13) instituição de programa de educação e autoaprimoramento; 14) engajamento de todo o conjunto da empresa.

É interessante notar que tais princípios definem-se pela presença de forte conteúdo ideológico, que se traduz na exigência de atitudes e valores, cujos fundamentos estão baseados em idéias que apelam à legitimidade, cooperação, harmonia, comprometimento, confiança, convergência de ações e que deve representar uma mudança cultural em favor de completa identificação com a empresa. Nesse sentido, os aspectos comportamentais adquirem relevância na divulgação e avaliação. A dedicação, o esforço e a não-adesão aos sindicatos são considerados pelo "líder" da empresa, devendo ser demonstrada, também, consonância com os objetivos da empresa e com a filosofia do PQT.

Essa proposta de gestão apóia-se numa transformação cultural que atingiria a empresa como um todo, incluindo a esfera gerencial e a alta gerência. Nesse sentido, apregoa-se a necessidade de redução dos níveis hierárquicos e de descentralização e de autogerenciamento de departamentos/setores, a delegação de tarefas e o compartilhamento de responsabilidades, a circulação de informações (os objetivos e os planos da empresa devem ser amplamente conhecidos e divulgados) e a transparência nas decisões. Tais recomendações configuram a denominada Gestão Participativa (GP) que apregoa a tomada de decisão por consenso que deve se traduzir na garantia do comprometimento do grupo com os objetivos da empresa, de tal forma que eles se transformem em preocupação central na vida do trabalhador.

De acordo com Lin Cheng Wen Tzeng (1994), Qualidade Total (QT) quer dizer gerência da qualidade nas seguintes dimensões: qualidade intrínseca dos serviços oferecidos pelos vários setores da instituição, custo desses serviços, atendimento aos clientes, segurança dos clientes na utilização de seu serviço e da equipe na execução do trabalho. Para ele, a Gerência de Qualidade Total (GQT) é um modelo segundo o qual todas as pessoas, em todos os níveis hierárquicos de uma organização, engajamse ativamente em ocupações de obtenção, manutenção e melhoria da qualidade de seu trabalho. Para isso, requer-se que todos os "colaboradores" saibam gerenciar o seu próprio trabalho, independente do cargo que ocupam. Nesta perspectiva, gerenciar significa: 1) planejar as metas a serem alcançadas com o trabalho e os métodos que possibilitem atingir as metas estabelecidas; 2) executar de acordo com o plano definido; 
3) verificar os resultados alcançados em comparação com as metas estabelecidas; 4) atuar corretivamente para prevenir contra a recorrência de resultados indesejáveis. Para o autor, que defende o PQT como única forma de melhoria da qualidade dos serviços, inclusive educacionais (desconsiderando a especificidade de objetivos e, portanto, de estratégias das áreas), argumenta que "a GQT é uma estratégia que auxiliará as instituições educacionais a melhorar a qualidade do seu trabalho, por meio de um enfoque gerencial nas suas atividades administrativas e pedagógicas" (Tzeng, 1994:185).

Tzeng, relatando a experiência de participar do processo de implementação da GQT na rede estadual do ensino fundamental, que, em Minas Gerais, representa a Fundação Cristiano Ottoni (FCO), afirma

"Técnicas e processos de qualidade e produtividade podem ser transplantados
com sucesso para a educação, modelos do setor empresarial e industrial podem
ser usados na elaboração do currículo e horários e na ministração do ensino,
processos de qualidade podem melhorar o gerenciamento e a operação de
instituições educacionais e simultaneamente melhorar o ambiente de
aprendizagem e o desempenho dos alunos" (Tzeng, 1994:186).

Por outro lado, Paro (1986) critica qualquer concepção de gestão que desconsidere a especificidade dos objetivos educacionais e do processo pedagógico. Uma das disparidades, com relação ao modelo de gestão empresarial em questão, é que o educando não é apenas objeto/produto do processo de produção pedagógica, pois "essa participação se dá à medida que o aluno entra no processo ao mesmo tempo como objeto e como sujeito da educação" (p.141). Outra disparidade é a diferença do conceito de 'produto' da educação escolar, pois como avaliar o produto final da escola? Não se trata de considerar apenas os benefícios que a pessoa obtém com a educação, mas de perceber até que ponto os conhecimentos apropriados pelo educando servirão como instrumentos intelectuais, de que se apoderou de maneira crítica, a fim de contribuir para a transformação social. E, por último, o autor apresenta a natureza do saber envolvido no processo educativo escolar. "A restrição da aplicabilidade do modo de produção capitalista na escola se dá
fundamentalmente porque, no processo de produção pedagógico, está envolvido,
também, e principalmente, um tipo de saber cuja natureza não é meramente
instrumental, e que funciona, em vez disso, como matéria-prima no processo. Ou
seja, a dificuldade de aplicação plena do modo de produção capitalista, aí, reside
exatamente no fato de que este tipo de saber, em virtude de sua natureza de
matéria-prima, não pode alienar-se do processo de produção" (Paro, 1986:147-
48). 
Gentili (1994), criticando o PQT, argumenta que tal programa caracteriza-se por seu sentido microinstitucional, já que

\begin{abstract}
"A idéia que atravessa este projeto é que, com uma série de estratégias de tipo participativo que traduzem no cotidiano escolar a filosofia da qualidade, a instituição educacional muda e suas práticas dominantes se transformam. Tratase do que se poderia chamar de otimismo contagioso na função redentora da qualidade" (Gentili, 1994:145. Grifos do autor).
\end{abstract}

O autor elucida que o discurso de Qualidade Total (QT) desloca o discurso de igualdade/desigualdade, da justiça/injustiça, e o da participação política numa esfera pública de discussão e decisão, tornando quase impossível pensar numa sociedade que transcenda os imperativos do mercado e do capital.

O transplante da teoria administrativa de QT para a educação insere-se no processo de reestruturação dos serviços prestados às áreas sociais, visando atrelar a educação aos objetivos mercantis. É como se o valor da educação não fosse social e sim econômico. Trata-se de fazer com que as escolas preparem melhor seus alunos para a competitividade do mercado e, ainda, de utilizar a educação como veículo de transmissão de idéias que proclamam as excelências do livre mercado.

Todo esse processo de definição e/ou redefinição de matrizes conceituais insere-se num processo de redefinição do papel do Estado, principalmente, diante das questões sociais. No âmbito político-econômico, as medidas reformistas que interferem substancialmente na manutenção de uma determinada política educacional são, de acordo com Silva (1994): a) equilíbrio orçamentário, sobretudo mediante a redução dos gastos públicos; b) abertura comercial, pela redução das tarifas de importação e eliminação das barreiras não-tarifárias; c) liberalização financeira, por meio de reformulação das normas que restringem o ingresso de capital estrangeiro; d) desregulamentação dos mercados, pela eliminação dos instrumentos de intervenção do Estado, como controle de preços, incentivos, etc.; e) privatização das empresas e dos serviços públicos; f) publicização ou transformação de órgãos estatais em entidades públicas não-estatais, de direito privado e sem fins lucrativos; g) terceirização ou contratação de serviços prestados por terceiros.

Segundo Paro (2000), relativamente a essa liberdade de mercado também no âmbito educacional, o neoliberalismo está referindo-se à necessidade de deixar que as relações se dêem de acordo com as regras de mercado, sem interferências em seu "natural" desenvolvimento. Diz Paro que a verdadeira liberdade humana deve possuir uma especificidade histórica, que não brota naturalmente, mas deve ser construída pelo homem, uma vez que é produto de sua atividade humana e deverá ser individual, e 
também coletiva, uma vez que ninguém consegue sozinho produzir sua própria existência, ou seja, a construção de sua liberdade se dá numa construção dialética, ancorada em uma relação entre o âmbito individual e o coletivo determinados pelo momento histórico ao qual pertencem.

Sobre essa questão Paro vai citar duas dimensões que se complementam:

“... ao se admitir que a construção do homem histórico se dá a partir de uma relação de verticalidade homem-natureza, na qual o primeiro entra como sujeito e o segundo como objeto de sua ação, só se pode admitir que a relação homem-homem seja de horizontalidade, na qual ambos sejam sujeitos. Se me suponho humano por minha posição de sujeito diante da natureza, ao submeter um semelhante, com minha dominação, à condição de objeto, nego nele, (portanto nego em mim) a condição de sujeito, reduzindo-o (e reduzindo a mim, seu semelhante) à condição natural. Conclui-se, com isso, que qualquer tipo de dominação é desumana, pois concorre para negar a própria especificidade histórica do homem" (Paro, 2001:49).

A segunda dimensão diz respeito à construção da liberdade feita de forma coletiva, na qual seja respeitado e preservado o direito de todos. Para que isso seja possível, necessita-se de um elemento de mediação, que seria a democracia.

“... esse caráter mediador da democracia revela mais uma vez a diferença que há entre a condição natural de liberdade e sua conotação histórica. O pássaro não precisa de mediação para ser "livre" porque ele não é autor de sua "liberdade". Mas, para os homens, a liberdade que os constitui historicamente não se apresenta naturalmente, mas é construída em colaboração com outros..." (Paro, 2001:53)

Tal transplante, para sua efetiva implementação, dispõe de alguns mecanismos, de procedência neoliberal, que, segundo Tomaz Tadeu da Silva (1994), são a construção da política como manipulação do sentimento, a transformação do espaço de discussão política em estratégias de convencimento publicitário, o estímulo, através de slongas educacionais, a suposta eficiência e produtividade da iniciativa privada em oposição à ineficiência e ao desperdício dos serviços públicos e a redefinição de cidadania pela qual o agente político se transforma em agente econômico e o cidadão em consumidor.

É nesse projeto global que se insere a redefinição da educação com pressupostos mercadológicos, atribuindo-se à gestão, com caráter fetichizado ${ }^{8}$, a

\footnotetext{
${ }^{8}$ Marx nos diz que, na sociedade capitalista, os objetos materiais possuem certas características que lhes são conferidas pelas relações sociais dominantes, mas que aparecem como se lhes pertencessem naturalmente. Dada a incapacidade dos homens de perceber como sociais os frutos de seu trabalho, as relações sociais adquirem uma relação de "coisas", parecendo enfeitiçar-se pela aparência material das mercadorias. "A ilusão do fetichismo brota da fusão da característica social com as suas configurações materiais: o valor parece inerente às mercadorias, natural a elas como coisas. Por extensão desse
} 
responsabilidade de liderança, ou de fio condutor nas palavras de Frigoto (1994). Esse valor econômico e desprovido da necessária consciência sobre os aspectos sociais inerentes no produto está sendo atribuído á educação através das estratégias neoliberais já mencionadas neste trabalho.

Pablo Gentili (1994) contextualiza o processo de redefinição dos argumentos e estratégias neoliberais. Na década de 80 , ainda que, graças às lutas populares, algumas conquistas democráticas tivessem sido arrancadas do Estado, não se consolidou uma política tendente à democratização dos direitos de cidadania e a uma ampliação dos espaços públicos.

Nesse contexto, o descontentamento com a qualidade dos serviços públicos torna-se uma demanda tanto dos setores neoliberais quanto das camadas populares. $\mathrm{A}$ diferença entre os dois setores é que os primeiros associam qualidade com eficiência e produtividade, enquanto os segundos primam pela democratização com qualidade, que converge para a consolidação, ampliação e universalização de espaços públicos como questão central que remete à forma democrática de sociedade.

Nesse sentido, a retórica conservadora da qualidade no campo educativo ganha força e hegemonia, devido à ocultação dos objetivos intrínsecos mercantis, presumindo uma dinâmica que Gentili chama de "duplo processo de transposição", o qual remete ao deslocamento do problema da democratização ao da qualidade e à transferência dos conteúdos que caracterizam a discussão sobre política educacional para da qualidade produtivo-empresarial.

$\mathrm{Na}$ explicação neoliberal temos uma profunda crise de gerenciamento na política educacional. Em suma, uma profunda crise de qualidade. Para a superação de tal crise, o progresso técnico e a administração assumem papel crucial, como mencionado acima, adquirindo um caráter fetichizado. Fetichizado no sentido de que a administração, sendo tratada como mercadoria, como se fosse a "mão invisível" do mercado, seguindo suas "leis naturais" irá resolver todo e qualquer problema social. Independente da sua área de abrangência estará sempre disponível e a serviço dos

\footnotetext{
fetichismo elementar, qualquer coisa, ao desempenhar o papel de DINHEIRO (...), converte-se na verdadeira encarnação do valor, na concentração pura e aparente de um poder que é de fato, social. De modo similar, no fetichismo do capital, as relações econômicas específicas que dotam os meios de produção da condição de CAPITAL são obscurecidas. (...) Assim, as propriedades conferidas aos objetos do processo econômico, verdadeiras forças que sujeitam as pessoas ao domínio deste processo, são como que uma espécie de máscara para as relações sociais peculiares ao capitalismo. (...) O que na verdade é social aparece como natural; uma relação que é de exploração parece ser uma relação justa" (Bottomore, 2001:149-150).
} 
interesses do capital, mas de maneira disfarçada, mascarada, pois tal atribuição econômica do capitalismo para a administração oculta as verdadeiras relações sociais subjacentes a ela.

Tem-se, portanto, o deslocamento das explicações políticas para questões técnicas, por conseqüência do desvio do debate sobre qualidade ${ }^{9}$, enquanto direito social e público, para o campo da eficiência e produtividade. Nessa operação, os problemas sociais e educacionais não são tratados como questões políticas, como resultado de lutas em torno da distribuição desigual de recursos materiais, simbólicos e de poder, mas como questões técnicas, de eficácia na gerência e administração de recursos humanos e materiais. Além disso, Paro (1986) afirma que os mecanismos de administração capitalista são tomados como transplantáveis para a situação da escola, sob justificativas meramente técnicas, sendo tratados de maneira autônoma, desvinculados dos condicionantes sociais e econômicos que os determinam.

Os argumentos neoliberais afirmam:

“... A crise de produtividade da escola não sintetiza outra coisa senão a crise do centralismo e da burocratização mediante o acesso das massas às instituições educacionais e, ao mesmo tempo, a eficiência produtiva que deve caracterizar as práticas pedagógicas nas escolas de qualidade" (Gentili, 1998:17).

Para eles, a escola está em crise porque nela não se instalaram os critérios competitivos que garantem uma distribuição diferencial do serviço, que se fundamente no mérito individual dos "usuários" do sistema. Trata-se de um complexo problema administrativo cuja solução não requer aumento de recursos, mas uma destinação mais eficaz dos mesmos. Para isso, como condição imprescindível, precisa-se fazer uma profunda reforma administrativa que se apóie nos PQT. Em tal reforma tudo se reduz a uma questão de melhor gestão e administração que, segundo Paro (1986), precisa dissimular as condições em que se dá a subordinação do trabalho escolar ao capital e, ao mesmo tempo, atenuar os efeitos nocivos mais imediatos dessa subordinação.

"Assim, em acréscimo aos meios de controle inerentes ao processo de produção capitalista, a administração passou a adotar medidas tendentes a reduzir a resistência do trabalhador e a melhor adaptá-lo ao processo de trabalho. Essas medidas vão de relações humanas mais amistosas e cordiais entre os trabalhadores e entre esses e seus superiores hierárquicos, passando pela modificação de algumas rotinas de trabalho que visem torná-lo menos monótono e cansativo, através do 'enriquecimento de tarefas', chegando até o favorecimento da participação dos trabalhadores em certas decisões empresariais, através de algum esquema de co-gestão" (Paro, 1986:70).

\footnotetext{
${ }^{9}$ De acordo com Gentili (1994), o discurso da qualidade referente ao campo educacional começou a desenvolver-se em fins da década de 80 como contraface do discurso da democratização.
} 
Além disso, busca-se maximizar recursos e proporcionar serviços sociais de "qualidade" para todos, constituindo-se um novo setor com possibilidade de transferência parcial ou total da ação pública estatal para agentes da sociedade civil, seguindo a lógica de flexibilização do mercado. Esta perspectiva de política educacional, viabilizada principalmente pela forma de gestão, é denominada por alguns autores como Gestão Compartilhada.

A Gestão Compartilhada é a expressão concreta do mencionado transplante dos mecanismos mercantis para a política educacional. Ela possui relações estreitas com a filosofia da GQT, que se respalda nos ditames neoliberais.

Na busca pela redefinição de um novo padrão de acumulação do capital, a GQT enfatiza os aspectos comportamentais, ressignificando a forma de alienação do trabalhador, que não se dá mais através da intensa divisão social do trabalho, mas através de mecanismos "modernos", procurando a obtenção do consenso acerca dos objetivos da empresa. Em tais mecanismos "modernos" inserem-se as formas de divulgação e informação mercantis, ou seja, são criados slogans educacionais ${ }^{10}$ que facilitam o processo de inculcação alienada da ideologia educacional neoliberal, sendo este disseminado através de programas comportamentais e motivacionais que se denominam formativos. A relação entre marketing, divulgação e propaganda, com os slogans educacionais e a fetichização da educação vai configurando e encorpando cada vez mais a imersão da lógica mercadológica na educação.

Entendendo-se a educação como uma mercadoria, ela merece marketing e propaganda como estratégia de venda de qualquer produto. Tais propagandas alimentadas por slogans educacionais ${ }^{11}$ demonstram caráter doutrinário que auxilia na obtenção do consenso acerca dos objetivos educacionais mercantis, alimentando a fetichização da educação.

Souza (2001), analisando tal imersão na política educacional do Paraná, conclui

“... ao proporem a gestão participativa, os seminários de gestão escolar têm enfatizado um caráter voluntarista, quando remetem a solução dos problemas educacionais a uma mudança de atitude por parte dos envolvidos com a escola, através da racionalização dos gastos, liderança, competência, iniciativa e

\footnotetext{
${ }^{10}$ De acordo com Scheffler (1974), os slogans educacionais proporcionam símbolos que unificam as idéias e atitudes-chaves dos movimentos educacionais. Eles podem, aos poucos, ser utilizados muito mais como doutrinas do que simplesmente como símbolos. No caso do Paraná, a doutrina pretendida é a da Gestão Compartilhada e os slogans acerca disso é a Qualidade Total, a Escola de Excelência, etc.

${ }_{11}$ Tais slogans tornam-se um conjunto de símbolos que, no contexto da política educacional do Paraná, caracteriza uma doutrina ideológica. Eles auxiliam na manutenção da crença de que as leis desiguais do mercado são naturais. Por isso o enorme estímulo dado, pelo governo de Jaime Lerner, aos projetos que vislumbravam a propaganda e o marketing como inerentes aos objetivos educacionais.
} 
criatividade; tal concepção desvia a atenção dos problemas de ordem material para um enfoque organizacional, colocando a força motriz da mudança da realidade no campo das idéias e desconsiderando as especificidades da educação escolar como locus de formação humana, ao transferir linearmente para a escola conceitos da administração empresarial" (Souza, 2001:98).

No entender de Paro (1986), a gestão conservadora ${ }^{12}$, na prática, acaba por atender objetivos que mais condizem com interesses dominantes,

"Como a própria sonegação do saber, ou a utilização da escola como álibi na solução de problemas sociais, ou ainda a transmissão de conteúdos vinculados aos interesses dominantes e desprovidos de utilidade prática para a população. A escola passa, assim, a desempenhar, a seu modo, função semelhante àquela exercida pela empresa capitalista em seu papel de servir à exploração de uma minoria sobre os demais". (p.150)

Para o autor o tipo de gestão escolar constituído à imagem e semelhança da administração empresarial capitalista é incompatível com uma proposta de articulação da escola com os interesses da maioria da população. Para ele, a gestão escolar deve fundamentar-se em objetivos educacionais representativos dos interesses das amplas camadas dominadas da população que levem em conta a especificidade do processo pedagógico escolar, processo este determinado por esses mesmos objetivos.

"A Administração Escolar inspirada na cooperação recíproca entre os homens
deve ter como meta a constituição, na escola, de um novo trabalhador coletivo
que, sem os constrangimentos da gerência capitalista e da parcelarização
desumana do trabalho, seja uma decorrência do trabalho cooperativo de todos os
envolvidos no processo escolar, guiados por uma 'vontade coletiva', em direção
ao alcance dos objetivos verdadeiramente educacionais da escola" (Paro,
1986:160).

Contudo, a gestão escolar, em perspectiva democrática ${ }^{13}$ e democratizante, enquanto ação humana transformadora, deve estar adequada aos objetivos e necessidades educativas das classes populares. Defende-se, com isso, que o projeto social e a perspectiva de gestão escolar e de educação estejam interconectados com um escopo de acepções democráticas e que, seus mecanismos e estratégias estejam, sempre, a caminho do alcance dos objetivos e necessidades da ampla maioria da população.

\footnotetext{
${ }^{12}$ Podemos considerar a gestão compartilhada como conservadora, o que significa que seus mecanismos garantem a conservação da sociedade dividida em classes sociais.

${ }_{13}^{13}$ A gestão escolar, em perspectiva democrática, será discutida mais detalhadamente nos sub-temas seguintes.
} 


\section{ESQUEMA EXPLICATIVO I: A essência neoliberal imersa no fenômeno da gestão escolar e os aspectos intervenientes}

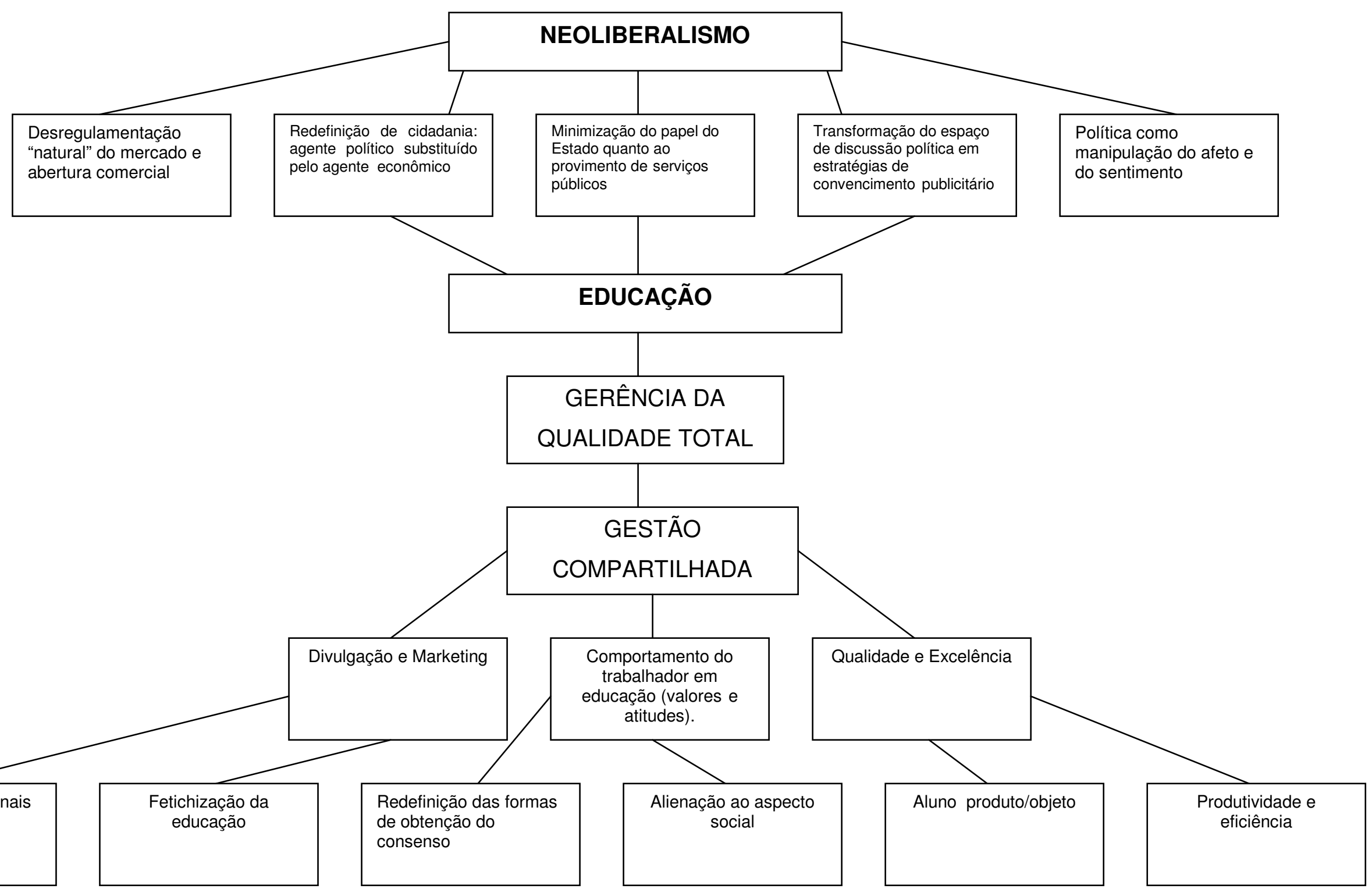




\section{DEMOCRACIA, EDUCAÇÃO E GESTÃO ESCOLAR}

\subsection{Conceito de democracia}

De acordo com Bobbio, a concepção liberal do Estado apregoa que a liberdade dos modernos é a liberdade individual em sua relação com o Estado, "aquela liberdade de que são manifestações concretas as liberdades civis e a liberdade política" (p.323), demonstrando, portanto, a identidade com a democracia direta que, segundo seus precursores, é a única forma de democracia compatível com o Estado liberal.

Segundo o autor, na concepção liberal de democracia é destacada a participação, com a ressalva de que esta participação seja livre, além de expressão e resultado de todas as outras liberdades.

"Na concepção liberal de democracia, a participação do poder político, que
sempre foi considerada o elemento caracterizante do regime democrático, é
resolvida através de uma das muitas liberdades individuais que o cidadão
reivindicou e conquistou contra o Estado absoluto. A participação é também
redefinida como manifestação daquela liberdade particular que indo além do
direito de exprimir a própria opinião, de reunir-se ou de associar-se para influir na
política do país, compreende ainda o direito de eleger representantes para o
parlamento e de ser eleito" (Bobbio, 2001:324).

Por outro lado, o Estado liberal, considerando a necessidade de participação popular, deve considerar também a soberania popular, como princípio democrático representativo, ainda que limitado a uma parte restrita dos cidadãos.

O autor salienta que a democracia representativa pode seguir duas direções: no alargamento gradual do direito do voto, que antes ficava restrita a uma parcela da população, e na multiplicação dos órgãos representativos.

Por outro lado, Maria Victória de Mesquita Benevides (1994) demonstra os problemas da representação no Brasil. Diz ela que, na realidade, a democracia não se constitui uma representação do povo diante do poder, mas, pelo seu caráter clientelista e patrimonialista, acaba por representar o poder diante do povo, numa relação desigual, afastando-se, portanto, da idéia de democracia como soberania popular (p.12, grifos meus).

Pablo Gentili (1998), examinando a teoria clássica de Hayek, elucida que, em tal perspectiva, a democracia deve ser definida em seus limites estritos, como uma regra de procedimento, ou seja, como um "método". Como "método", a democracia não tem uma moral que lhe seja própria, porquanto a atribuição de fins morais acaba conduzindo à sua deteriorização e quiçá ao seu desaparecimento. Nessa perspectiva, o Estado de 
Bem Estar Social acaba reforçando um solidarismo comunitarista baseado num falso ideal igualitário e num ameaçador antiindividualismo que impedem o alargamento da sociedade competitiva.

Em perspectiva socialista, o ideal democrático representa um elemento integrante e necessário, desde que haja o reforço da base popular. Diferencia-se do ideal liberal a partir do modo de entender o processo de democratização da sociedade. Nessa perspectiva, o sufrágio universal constitui o ponto de partida no processo de democratização do Estado. Além do sufrágio universal, o aprofundamento do processo de democratização acontece de dois modos: através da crítica da democracia apenas representativa e da conseqüente retomada de alguns aspectos da democracia direta e através da solicitação de que

"(...) a participação popular e também o controle do poder a partir de baixo se
estenda dos órgãos de decisão política aos de decisão econômica, de alguns
centros do aparelho estatal até à empresa, da sociedade política até à sociedade
civil pelo que se vem falando de democracia econômica, industrial ou de forma
efetiva de funcionamento dos novos órgãos de controle (chamados "conselhos
operários"), colegial, e da passagem do auto-governo para a autogestão" (Bobbio,
1986:325).

Para Carlos Nelson Coutinho (2000), as várias facetas que formam a democracia moderna decorre do desenvolvimento das necessidades de participação política e de socialização. Tais necessidades culminaram na ampliação das burocracias ligadas aos aparelhos executivos e representativos, surgindo, ao lado do Estado-coerção, o que Gramsci chamou de "sociedade civil".

Para o autor, a socialização da política manifestou-se por meio da criação de "associações particulares" (partidos, sindicatos, movimentos sociais), e, ao mesmo tempo, pela negação desse pluralismo, com a repressão das diversidades em nome de uma pretensa unidade política que provocou uma imposição coercitiva à "vontade de todos".

\footnotetext{
"Temos assim que, se a supressão do pluralismo conduz ao despotismo totalitário, a sua afirmação incontrolada leva ao liberal-corporativismo, o qual, em articulação com a burocratização do Estado, é o modo pelo qual a burguesia tenta por a seu serviço, ou pelo menos neutralizar, os resultados do processo de socialização da política" (Coutinho, 2000:31).
}

Isso implica uma relação hegemônica que se tornou um recurso decisivo da ação política. Diante da hegemonia burguesa, que defende prioritariamente interesses privados, o autor propõe a construção de uma hegemonia dos trabalhadores, configurando o que Gramsci chamou de novo "bloco histórico". Para isso, seria 
necessária a integração entre os organismos populares de democracia de base (criados de baixo para cima) e os mecanismos tradicionais de representação indireta (como os parlamentos).

"Se se mantiverem abertos à pressão daqueles organismos populares, os parlamentos podem adquirir uma nova função: podem ser o local de uma síntese política das demandas dos vários sujeitos coletivos, tornando-se assim a instância institucional decisiva da expressão da hegemonia" (Coutinho, 2000:33).

Essa proposta de uma forma de governo baseada na articulação entre democracia representativa e democracia direta faz parte da defesa de alguns autores que discutem tal temática, entre as quais Maria Victória Mesquita de Benevides. A autora, discutindo a relação entre cidadania e democracia, defende a cidadania ativa ${ }^{14}$ imersa num governo de democracia semidireta.

"Defender a cidadania ativa, no contexto da democracia semidireta, implica o reconhecimento da complementaridade entre a representação política tradicional e a participação popular diretamente exercida" (Benevides, 1994).

Enfim, as formas de governo apresentadas nesta etapa do trabalho não ocorrem isoladamente ou univocamente, pois "a relação entre democracia de massas (ou socialista) com a democracia liberal não é uma relação de negação, mas de superação dialética: a primeira conserva e eleva a nível superior as conquistas da segunda" (Coutinho, 2000:38. Grifo do autor).

Como ressaltou Benevides, é através de uma educação política que se conseguirá formar cidadãos ativos que tomarão parte das questões que lhes dizem respeito através dos canais de participação de um governo de democracia semidireta.

\footnotetext{
${ }^{14}$ Nas palavras da autora, cidadania ativa consiste em instituir "o cidadão como portador de direitos e deveres, mas essencialmente criador de direitos para abrir novos espaços de participação política". Segundo ela, para tanto, faz-se necessária a educação política do povo, para que não ocorra a cidadania passiva, tão presente nos dias atuais, a qual afirma ser "aquela outorgada pelo Estado, com a idéia moral do favor e da tutela" (Benevides, 1994:09).
} 


\title{
3.2. CONCEPÇÃO DE HOMEM, SOCIEDADE E EDUCAÇÃO: MATRIZES CONCEITUAIS NORTEADORAS DE UMA DETERMINADA CONCEPÇÃO DE DEMOCRATIZAÇÃO DO ENSINO
}

Numa perspectiva conservadora, a concepção humana consiste na condição de que os indivíduos devem adaptar-se à sociedade vigente. Sentido a-histórico e funcionalista de homem. Só há cobrança e reprodução de gestos e atitudes que revelam domestificação, passividade e massificação do homem (Freire, 1959).

\begin{abstract}
"A possibilidade humana de existir_forma acrescida de ser_mais do que viver faz do homem um ser eminentemente relacional. Estando nele, pode também sair dele. Projetar-se, discernir, conhecer. É um ser aberto. Distingue o ontem do hoje. $\mathrm{O}$ aqui do ali. Essa transitividade do homem faz dele um criador de cultura. A posição que ocupa na sua circunstância é uma posição dinâmica. Trava relações com ambas as faces do mundo_ a natural, para o aparecimento de cujos entes o homem contribui, mas a que confere uma significação que varia ao longo da história e a cultura, cujos objetos são criação sua" (Freire, 1959:08).
\end{abstract}

Segundo Marx, é através do trabalho que o homem se constrói e constrói relações com os outros homens e com a natureza. Através dessas relações estabelecidas e as circunstâncias, principalmente econômicas, o homem constrói sua história. Isso porque só ele é capaz de estabelecer objetivos, calcados em valores, e de buscar sua concretização. Nesse sentido, é também "o trabalho que empresta ao homem sua característica histórica" (Paro, 2001).

"O relacionamento entre os homens, para manter-se na esfera do humano, para não se degradar ao nível da relação entre coisas (âmbito da necessidade), precisa ser caracterizado pela colaboração e pelo reconhecimento do caráter humano dos indivíduos envolvidos (âmbito da liberdade) dominação é pois, negadora da condição humana" (Paro, 2001).

De acordo com o autor, a partir do momento em que esta relação se estabelece desigualmente pautada na dominação que os donos dos meios de produção exercem sobre os que não possuem meios de produção, mas apenas sua força de trabalho, esta relação social apresenta-se injusta e desigual; embora se anuncie democrática, é uma relação inerente aos preceitos liberais.

"Também a democracia, apesar de sua origem remota, transformou-se
enormemente em seu percurso histórico, enriquecendo-se de novos significados,
à luz dos quais precisa ser compreendida. Assim, ela já não deve ser vista
apenas em sua conotação etinológica do "governo do povo" ou em sua versão
formal de "vontade da maioria", mas em seu significado mais amplo e atual de
mediação para a construção da liberdade e da convivência social, que inclui todos
os meios e esforços que se utilizam para concretizar o entendimento entre grupos
e pessoas, a partir de valores construídos historicamente" (Paro, 2001:10). Na concepção liberal "... a sociedade é produzida por nossas carências e o governo por nossa perversidade, a primeira promove a nossa felicidade 
positivamente mantendo juntos os nossos afetos, o segundo negativamente mantendo sob freio nossos vícios. Uma encoraja as relações, o outro as distinções. A primeira protege, o segundo pune. A sociedade é sob qualquer condição uma bênção; o governo, inclusive na sua melhor forma, nada mais é do que um mal necessário e na sua pior forma é insuportável" (Bobbio, 2001:20).

Para alguns, a sociedade industrial de massa ou a sociedade de consumo de massa é a sociedade democrática. Pensam eles que a integração da população ao mercado da produção industrial, inclusive da população ainda à margem do grande consumo, é o ato final de edificação da sociedade democrática. A incorporação da população ao mercado e ao crescimento industrial é importante.

Para Evaldo Vieira (1992), sociedade democrática é aquela na qual ocorre real participação de todos os indivíduos nos mecanismos de controle das decisões havendo, portanto, real participação deles nos rendimentos da produção.

"Participar dos rendimentos da produção envolve não só mecanismos de distribuição da renda, mas sobretudo níveis crescentes de coletivização das decisões, principalmente nas diversas formas de produção" (Evaldo Vieira, 1992:13).

É precisamente a criticidade, segundo Paulo Freire, o elemento fundamental da mentalidade democrática.

"Quanto mais crítico um grupo humano, tanto mais permeável, em regra. Tanto mais democrático, quanto mais organicamente ligado às condições de sua circunstância. Tanto menos experiência democrática, que exija o conhecimento de sua realidade, pela participação nela, pela sua intimidade com ela, quanto mais superposta a essa realidade e inclinado a formas ingênuas de encará-la. A formas mais ingênuas de percebê-la. A formas verbosas, palavrescas de representá-la" (Freire, 1959:95).

A sociedade e, conseqüentemente, a educação vão-se desenvolvendo a partir de movimentos contraditórios. Ao mesmo tempo que temos que transformar a educação inserida nessa sociedade capitalista, é necessária uma nova perspectiva de educação, para que ela contribua significativamente para a transformação desta mesma sociedade.

"Por um lado, é preciso uma mudança das condições para criar um sistema de instruções novo; por outro lado, é preciso um sistema de instrução já novo para poder mudar as condições sociais. Por conseguinte, é preciso partir da situação atual" (Machado, 1991: 224).

E é procedimento coerente com essa perspectiva a defesa da escola pública, que garante a emancipação da maioria da população, com a contribuição da educação, sem que com isso se queira atribuir a ela a responsabilidade de 
"salvadora da pátria" (como apregoam os neoliberais) nem, ao mesmo tempo, esperar que a mudança ocorra de cima para baixo.

A educação no Brasil, particularmente nas décadas de 60 e 70, de prática social que se definia pelo desenvolvimento de conhecimentos, habilidades, atitudes, concepções e valores articulados às necessidades e interesses das diferentes classes e grupos sociais, foi reduzida, pelo economicismo a mero fator de produção de "capital humano", passando a definir-se como uma técnica de preparar recursos humanos para o processo de produção.

"Essa concepção de educação como "fator econômico" vai constituir-se numa espécie de fetiche, um poder em si que, uma vez adquirido, independentemente das relações de força e de classe, é capaz de operar o "milagre de equalização social, econômica e política entre indivíduos, grupos, classes e nações" (Frigoto, 1995:18).

A década de 80 é marcada por movimentos defensores da democratização ampla da sociedade, dentre os quais havia o da educação. Entretanto, demonstra um movimento contraditório, pois que, ao lado da efervescência dos preceitos democráticos, assistimos ao processo de reestruturação e redefinição das estratégias de acumulação do capital, ressignificando as formas de intervenções sociais, entre as quais a educação ${ }^{15}$.

$\mathrm{Na}$ década de 90, intensificam-se os mecanismos de acumulação flexível do capital. Entre eles podemos identificar a facilitação da mercantilização e privatização da educação, sendo esta viabilizada pela reestruturação da política educacional nos âmbitos federal, estadual e municipal.

Acredita-se que a educação é a preparação para o exercício da cidadania e para a luta em favor de uma escola pública de qualidade. Para tanto é necessário que nos indignemos e busquemos a garantia por esse exercício, rejeitando, segundo Gaudêncio Frigoto, o desmantelamento da escola pública, o reforço da educação como negócio, o dualismo que materializa uma quantidade e qualidade de serviços educacionais diversos para as classes trabalhadoras e para a classe dominante, 0 tecnicismo e fragmentação que diluíram e esmaeceram os processos de

\footnotetext{
15 "Tomando como referência o Programa de reformas desencadeado pelo neoliberalismo na América Latina, a partir dos anos 80, podemos identificar algumas diretrizes para a Reforma Educacional: a educação escolar deve ser tratada como uma questão técnica e não política; o discurso de igualdade e justiça social deve ser substituído pela noção de cidadão; a reforma educacional deve orientar-se para a publicização das instituições públicas que promovam a educação formal; estabelecimento de mecanismos de controle e a submissão da educação às demandas do setor produtivo". (Sapelli, 2003:24) Vale ressaltar que o conceito de cidadão é entendido como "cidadão privatizado, responsável, dinâmico: o consumidor" ( Gentilli, 1998:20).
} 
conhecimento; a proletarização do magistério público, entre outros mecanismos que favoreçam o processo de acumulação flexível do capital.

"A luta é justamente para que a qualificação humana não seja subordinada às leis
do mercado e à sua adaptabilidade e funcionalidade, seja sob a forma de
adestramento e treinamento estreito da imagem do mono domesticável dos
esquemas tayloristas, seja na forma da polivalência e formação abstrata,
formação geral ou policognição reclamadas pelos modernos homens de negócio"
(Frigoto, 1995:30).

Marx e Engels postulam a união do trabalho manual, industrial, produtivo, com o trabalho intelectual. Esta possibilidade implica a supressão da relação capitalista que, dominantemente, transforma o trabalho de criador da vida humana em alienador da vida do trabalhador.

Pautado nesta proposta, Gramsci ${ }^{16}$ desenvolveu o conceito da Escola Unitária, denominada também Politecnia que se propõe a tarefa de inserir os jovens na atividade social, depois de tê-los levado a um certo grau de materialidade e capacidade, à criação intelectual e prática e a uma certa autonomia na orientação e na iniciativa" (Gramsci, 1988:121).

É essa perspectiva de educação, como elemento potencial de transformação da sociedade, que se defende. Nela as camadas populares participam do processo de luta pela transformação social, através também da escola e sua organização interna, elaborando, com isso e a partir disso, seu próprio saber.

Procurando deixar mais evidente as diferenças de concepções explicitadas será apresentado esquematicamente o quadro I a seguir.

\footnotetext{
${ }^{16} \mathrm{O}$ pensador nos demonstra que "a tendência democrática, intrinsecamente, não pode consistir apenas em que um operário manual se torne qualificado, mas em que cada "cidadão" possa se tornar "governante" e que a sociedade o coloque, ainda que abstratamente, nas condições gerais de poder fazêlo: a democracia política tende a fazer coincidir governantes e governados, assegurando a cada governo técnica geral necessárias ao fim do governar. Mas o tipo de escola que se desenvolve como escola para o povo não tende mais nem sequer a conservar a ilusão, já que ela cada vez mais se organiza de modo a restringir a base da camada governante tecnicamente preparada, num ambiente social político que restringe ainda mais a iniciativa privada no sentido de fornecer esta capacidade e preparação técnicopolítica, de modo que na realidade, retorna-se às divisões em ordem "juridicamente" fixadas e cristalizadas ao invés de superar as divisões em grupos: a multiplicação das escolas profissionais, cada vez mais especializadas, é uma manifestação desta tendência " (Gramsci, 1988:137).
} 


\section{QUADRO I: Concepção de homem, sociedade e educação nas concepções conservadora e transformadora.}

\begin{tabular}{|c|c|c|}
\hline & CONSERVADORA & TRANSFORMADORA \\
\hline $\begin{array}{l}\text { Concepção } \\
\text { de homem }\end{array}$ & $\begin{array}{l}\text { A concepção humana consiste em os } \\
\text { indivíduos deverem se adaptar à sociedade } \\
\text { vigente. Sentido a-histórico e funcionalista } \\
\text { de homem. }\end{array}$ & $\begin{array}{l}\text { Concepção de ser humano como sujeito } \\
\text { histórico que se constrói na relação com a } \\
\text { natureza e com os demais seres humanos, } \\
\text { sendo o "trabalho que empresta ao homem } \\
\text { sua característica histórica". }\end{array}$ \\
\hline $\begin{array}{l}\text { Concepção } \\
\text { de educação }\end{array}$ & $\begin{array}{l}\text { A educação é um "fator econômico", } \\
\text { constituiu-se numa espécie de fetiche. É } \\
\text { capaz de operar o milagre de equalização } \\
\text { social, econômica e política. }\end{array}$ & $\begin{array}{l}\text { A educação constitui a mediação pela qual os } \\
\text { seres humanos garantem a manutenção de } \\
\text { seu caráter histórico, através da apropriação e } \\
\text { produção de saber. Conceito de Escola } \\
\text { Unitária-Politecnia. }\end{array}$ \\
\hline $\begin{array}{l}\text { Concepção } \\
\text { de sociedade }\end{array}$ & $\begin{array}{l}\text { Relação político-econômico-social pautada } \\
\text { na dominação dos donos de meios de } \\
\text { produção sobre os que não possuem } \\
\text { propriedade e apenas sua força de trabalho. }\end{array}$ & $\begin{array}{l}\text { Sociedade democrática é aquela na qual } \\
\text { ocorre real participação de todos os indivíduos } \\
\text { nos mecanismos de controle das decisões } \\
\text { havendo real participação nos rendimentos de } \\
\text { produção. }\end{array}$ \\
\hline
\end{tabular}




\title{
3.3. A DEMOCRATIZAÇÃO DO ENSINO PÚBLICO, SEUS ELEMENTOS CONSTITUTIVOS E SUA RELAÇÃO COM A GESTÃO ESCOLAR
}

A educação, segundo Paro, precisa apropriar-se dos valores democráticos, uma vez que ninguém nasce democrata ou com requisitos culturais necessários à aquisição da democracia. Portanto, cabe à escola possuir, entre os seus objetivos de educação, a formação para a democracia. De acordo com o autor, a gestão escolar precisa ser pelo menos duplamente democrática:

\begin{abstract}
“... porque ela se situa no campo das relações sociais onde,[...] torna-se ilegítimo o tipo de relação que não seja de cooperação entre os envolvidos.[...] porque também [...] a característica essencial da gestão é a mediação para a concretização de fins; sendo seu fim a educação e tendo esta um necessário componente democrático, é preciso que exista a coerência entre o objetivo e a mediação que the possibilita a realização, posto que fins democráticos não podem ser alcançados de forma autoritária" (Paro,2001:04).
\end{abstract}

Democratizar a educação, segundo Bueno (2001), não é simplesmente reafirmar intenções no plano do discurso. Para a autora, é preciso que a prática da cúpula administrativa flua visando liberar as iniciativas das escolas e não impondo soluções muitas vezes inviáveis, com o fim de orientar a busca da própria melhoria e não de ordenar. Diz ainda que a estrutura básica da administração educacional brasileira, apesar das plásticas e maquiagens, foi concebida e implantada para funcionar autocraticamente.

A defesa da eficiência e da eficácia na gestão do Estado expressa uma mudança radical na concepção que norteia a defesa e manutenção da democracia, pois ela deixa de estar restrita a um simples conjunto de regras para a escolha de lideranças e para o processamento de decisões e passa a compreender um conjunto de valores sociais aos quais os atores políticos fazem referência quando sua ação é questionada em público.

Para alcançar a meta de democratização do ensino, legitimada na constituição de 88, podemos destacar algumas medidas: fortalecimento da autonomia administrativo-pedagógica dos núcleos regionais de ensino, delegando-se-lhes a responsabilidade de acompanhar o cumprimento das metas estabelecidas pela administração central; mudanças curriculares e a correção de fluxo escolar; 
reorientação nos procedimentos burocrático-administrativos e financeiros entre os órgãos centrais, regionais, unidades escolares e instâncias municipais; ações que salientem a participação da sociedade civil no processo de recuperação e melhoria da qualidade do ensino público, instituindo-se ações conjuntas da APM com o setor privado lucrativo ou não-lucrativo e demais entidades da sociedade civil; e otimização do convênio entre prefeituras e Estado para transferência de escolas e professores aos municípios.

Licínio Lima, em sua obra "Organização escolar e democracia radical”, apresenta a proposta de Paulo Freire de democratização do ensino público em sua gestão em São Paulo, afirmando

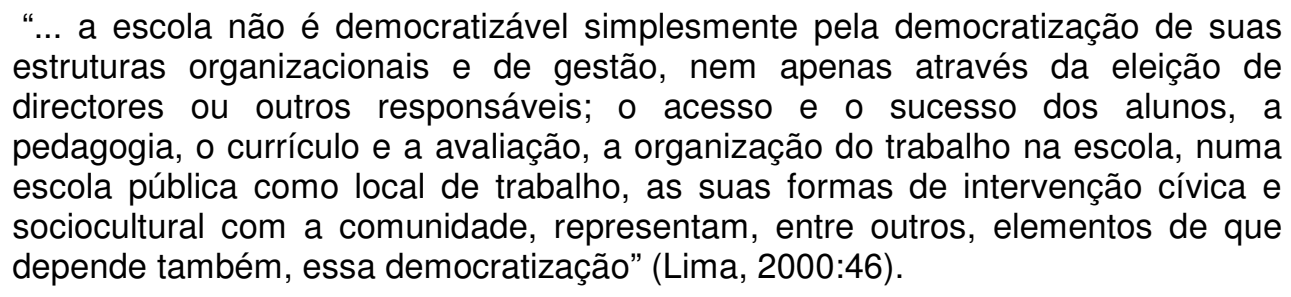

Nesta perspectiva, a concepção de organização democrática é revolucionária, e sua prática de participação e partilha do poder de decisão é indispensável à ação libertadora; é uma organização em que os indivíduos são sujeitos do ato de organizar-se, "exigindo a liderança mas recusando o dirigismo, o vanguardismo e a reificação, implicando autoridade sem autoritarismo, liberdade sem licenciosidade" (Lima, 2000:36).

A pedagogia democrática, ainda na perspectiva freiriana, tem por horizonte uma democracia radical, contra todas as formas de populismo e sectarismo, pelo ativismo crítico e militante através do qual se aprende, se vive e se cria a própria democracia, da escola à empresa, das associações à comunidade local. Trata-se de uma concepção de "democracia governante", de cidadãos e não de súditos, não limitada à democratização do Estado e de suas instituições políticas, mas relacionada à democratização da sociedade através do exercício da participação, com práticas dialógicas e anti-autoritárias contra a passividade e para a decisão e para a responsabilidade social e política.

Além disso, a associação de uma interpretação crítica da realidade a práticas políticas de mobilização organizacional pode gerar novas possibilidades democráticas e apoiar ações de tipo contra-hegemônico, valorizando o processo educativo como elemento central da ação política e da construção de uma 
democracia participativa que pressupõe, em Freire, uma Teoria do Sujeito. A educação para a democracia só é realizável através de ações educativas e de práticas pedagógicas democráticas, tendo a autonomia (individual e coletiva) como elemento decisivo à sua concretização.

"Essa prática educativa democrática, antidiscriminatória, uma prática 'educativo-
progressista' orientada para a realização dos educandos como seres livres e
conscientes, para a aproximação crítica entre a escola e a vida, currículo e
experiência social dos sujeitos, ensino e formação moral e cívica, formação
democrática e exercício efetivo de práticas democráticas e participativas na
escola, ao comprometer-se assim com a emancipação e a autonomia revela-se
uma 'pedagogia da autonomia" (Lima, 2000:88).

Acredita-se que, para deslanchar o processo de democratização do ensino público necessita, do ponto de vista qualitativo, funcionar como socialização do saber sistematizado, indispensável ao exercício de cidadania, assim como ocorre na produção e sistematização de um novo saber nascido das necessidades da prática social, e, do ponto de vista quantitativo, assegurar o acesso e a permanência da maioria da população na educação formal.

"Hoje democratizar a escola significa torná-la pública, gratuita e de boa qualidade
para as camadas populares, proporcionando-lhes o acesso e a permanência na
escola. Entendida como determinada historicamente, a escola é também o campo
de lutas para a tomada de consciência, por parte das camadas populares, dos
mecanismos de dominação que ocorrem na sociedade capitalista. A escola pode
contribuir para essa tomada de consciência pela elevação de sua qualidade"
(PIMENTA, 1998:124).

Busca-se a coerência entre tal perspectiva e a gestão escolar. Isso pode ser percebido nos estudos de Arroyo (1983) que considera que a democratização da administração deve buscar mecanismos para submeter as decisões ao debate e ao controle pela opinião pública. A gestão democrática, que se pretende, supõe a constituição de sujeitos coletivos através de formas de organização independentes, como a gestão colegiada. Esta deverá constituir núcleo de pressão e resistência, de cobrança do dever do Estado na garantia das condições para a realização do Projeto Político Pedagógico, gestado democraticamente, em vista das aspirações e necessidades da maioria da população.

Contudo, a gestão democrática deve: a) pressupor seu movimento com a conjuntura econômica e social; b) considerar o movimento dialético entre escola e sociedade; c) fundamentar-se em objetivos educacionais representativos dos interesses das amplas camadas dominadas da população; d) considerar a especificidade do processo pedagógico; e) criar mecanismos que possibilite a expressão e participação 
dos membros da comunidade escolar; f) trabalhar coletivamente para a transformação da escola, mudando o sistema de autoridade e a distribuição do próprio trabalho no interior da escola.

Entretanto, "é na práxis administrativa escolar, enquanto ação humana transformadora adequada a objetivos educativos de interesse das classes trabalhadoras que se encontrarão as formas de gestão mais adequadas a cada situação e momento histórico determinados"(Paro, p.161:1986).

Além disso, a comunidade escolar deve trabalhar nessa perspectiva transformadora e a serviço das classes populares, sendo partícipe da gestão democrática, articulando esse processo de envolvimento da comunidade, no estabelecimento das relações tanto com o grupo de trabalho quanto com a família e a comunidade, e, principalmente, na contribuição para que os alunos se apropriem do saber acumulado historicamente e com condições de produzirem outras formas de representações socioculturais, a partir de suas necessidades num dado momento histórico.

Uma proposta que dê conta de uma gestão escolar democrática pautada em relações horizontalizadas e coletivas é aquela, elaborada por Paro (1997), na qual haveria um Coordenador Geral de Escola, um Coordenador Pedagógico, um Coordenador Comunitário e um Coordenador Financeiro, formando, assim, um Conselho Diretivo. Nessa composição, a tomada de decisão seria coletiva, embora cada um tenha maior responsabilidade sobre os assuntos de sua área. Paralelamente a este Conselho Diretivo continuaria a existir o Conselho Escolar, de caráter consultivo e deliberativo. Desse modo, a figura do diretor, que hoje adquire centralidade, na gestão da escola, seria eximida de teor autoritário e dominador. 


\section{FUNDAMENTOS TEÓRICOS DA GESTÃO ESCOLAR: PARTICIPAÇÃO, DESCENTRALIZAÇÃO E AUTONOMIA}

Para analisar a gestão escolar e sua relação com a democratização do ensino é necessário compreender alguns conceitos e fenômenos que constituem a prática de gestão escolar. Para tanto, fez-se um aprofundamento dos conceitos e fenômenos de participação, descentralização e autonomia que irão nortear a reflexão e análise da gestão escolar e da educação paranaense. Tais conceitos, se esclarecidos e desmistificados, poderão indicar se a gestão escolar se pretende ou não democratizante.

\subsection{PARTICIPAÇÃO}

Quando pensamos em participação, relacionamos este conceito com mecanismos democráticos, até mesmo em conseqüência da luta, na década de 80 , pela democratização da sociedade, que reivindicava a participação ativa da sociedade civil e o controle social, nas esferas do Estado, sobre a administração pública. Entretanto, pela necessidade de reestruturação o capitalismo e o modelo liberal na década de 90 (re)apropriam-se do conceito de participação e redesenham seus objetivos e suas formas de intervenção, atendendo aos interesses da acumulação flexível do capital. Aliás, estão a favor da participação tanto os setores progressistas que desejam uma democracia mais autêntica, quanto os setores tradicionalmente não muito favoráveis aos avanços das forças populares ${ }^{17}$.

Com isso, pretende-se conceituar participação e demonstrar a influência do projeto político-pedagógico, na concepção de participação, e as formas de participação que resultam dessa concepção.

\footnotetext{
${ }^{17}$ Bordenave (1992) argumenta que a razão disso é que a participação oferece vantagens para ambos. Ela pode implementar-se tanto com objetivos de liberação e igualdade como para a manutenção de uma situação de controle de muitos por poucos.
} 


\subsubsection{Conceitos Básicos}

Qual a origem da palavra participação? De acordo com Bordenave (1992), ela vem da palavra parte. Participação é fazer parte, tomar parte ou ter parte. É possível, ainda, fazer parte sem tomar parte, representando a segunda expressão um nível mais intenso de participação. Em decorrência disso, eis a diferença entre participação passiva e participação ativa, a distância entre o cidadão inerte e o cidadão engajado.

Mesmo dentro da participação ativa, isto é, entre pessoas que "tomam parte", existem diferenças na qualidade de participação.

"A prova de fogo da participação não é o quanto se toma parte mas o como se toma parte" (Bordenave, 1992:23).

O autor afirma que a insatisfação com a democracia representativa, que se nota nos últimos tempos em alguns países, possivelmente se deva ao fato de os cidadãos desejarem cada vez mais "tomar parte" no processo de tomada de decisões em âmbito nacional e não somente nas eleições periódicas. A democracia participativa, enquanto forma de superação da participação passiva, seria então aquela em que os cidadãos sentem que, por "fazerem parte" da nação, "têm parte" real na sua condução e por isso "tomam parte" - cada qual em seu ambiente - na construção de uma nova sociedade da qual se "sentem parte".

Licínio Lima (2001) entende a participação como

"referência ao projeto político democrático, como afirmação de interesses e de vontades, enquanto elemento limitativo e mesmo inibidor da afirmação de certos poderes, como elemento de intervenção nas esferas de decisão política e organizacional, factor quer de conflitos, quer de consensos negociados". (p.71)

O autor, em sua obra "A escola como organização educativa". São Paulo: Cortez, 2001; classifica os tipos de participação em várias formas de operacionalização, graus, níveis e sobreposições. À participação passiva conceitualiza como

“... uma estratégia de não-envolvimento ou de um envolvimento mínimo, sem expressão na acção. Não se indiferentes aos cursos da acção e ao tipo de políticas e de decisões tomadas, os actores parecem descrer das possibilidades de influenciar as decisões ou recusam o preço que para tal poderiam ser forçados a pagar, preferindo remeter o papel de luta e reivindicação para certas minorias activistas, para uma vanguarda que ora valorizam e admiram, ora desvalorizam e criticam". (p.78) 
Ainda de acordo com a classificação do autor, um extremo das formas de participação seria a ativa.

\begin{abstract}
"A participação ativa caracteriza atitudes e comportamentos de elevado envolvimento na organização, individual ou colectivo. Traduz capacidade de mobilização para a acção, conhecimento aprofundado de direitos, deveres e possibilidades de participação, atenção e vigilância em relação a todos os aspectos considerados pertinentes, afirmação, defesa e alargamento das margens de autonomia dos actores e de sua capacidade de influenciar as decisões" (Lima, 2001:77).
\end{abstract}

Bordenave (1992) explicita um tipo de participação contraposta à participação ativa $^{18}$ que se caracteriza segundo preceitos neoliberais, e seria uma adaptação ao modelo participacionista da "Gerência da Qualidade Total", na qual ela tem como objetivo último o aumento da produtividade e, por conseguinte, o lucro. A esse modelo para participação, Lima (2001) denomina de participação decretada, por não ser conquistada como princípio e consagrada enquanto direito. Para o autor, a participação deve não somente ser conquista como princípio e consagrada como direito, mas deve, também, "constituir uma prática normal, esperada e institucionalmente justificada" (p.71).

Ainda em sua teoria, Bordenave afirma que a participação é uma necessidade fundamental do ser humano.

"A participação é o caminho natural para o homem exprimir sua tendência inata de realizar, fazer coisas, afirmar-se a si mesmo e dominar a natureza e o mundo. Além disso, sua prática envolve a satisfação de outras necessidades não menos básicas, tais como a interação com os demais homens, a auto-expressão, o desenvolvimento do pensamento reflexivo, o prazer de criar e recriar coisas, e, ainda, a valorização de si mesmo pelos outros" (Bordenave, 1992:16).

A participação é inerente à natureza social do homem, está presente em todas as etapas da evolução desde os tempos primitivos (tribos e clãs) até as associações, empresas, partidos políticos de hoje. Com isso, a nossa cultura de não-participação, por influência da hegemonia neoliberal, constitui uma agressão ao homem social, que é tolhido em uma necessidade intrinsecamente humana de caráter educativo. Por ser uma atividade eminentemente prática e socializadora, todos os problemas relacionados à convivência social são problemas da coletividade, e as soluções devem ser buscadas em conjunto, levando-se em conta os interesses da maioria.

"Assim, portanto, ávida em sociedade é uma necessidade de natureza humana, não se podendo falar do homem como indivíduo sem lembrar que esse indivíduo não vive sozinho, mas está sempre relacionado com outros indivíduos. Pode-se 
resumir essa idéia dizendo que o homem é um ser social por natureza e, por isso, tudo que ele tem ou realiza é tido ou realizado em sociedade" (DALLARI, 1991:13).

Bordenave (1992) argumenta que a participação tem duas bases complementares: a) base afetiva: participamos porque sentimos prazer em fazer coisas com os outros; b) base instrumental: participamos porque fazer coisas com os outros é mais eficaz e eficiente que fazê-las sozinhos. Entretanto, estas duas bases devem equilibrar-se mesmo quando entram em conflito ou uma delas se sobrepõe à outra. 


\subsubsection{BIFURCAÇÃO DO CONCEITO DE PARTICIPAÇÃO: PERSPECTIVA TRANSFORMADORA CONTRAPOSTA Å PERSPECTIVA NEOLIBERAL}

Do ponto de vista dos setores progressistas, a participação facilita o crescimento da consciência crítica da população, fortalece seu poder de reivindicação e a prepara para adquirir mais poder na sociedade.

Além disso, os serviços que o Estado presta ao povo, ou deveria prestar ou presta insuficientemente, seria mais eficiente, se os representantes do povo se esforçassem em corresponder às necessidades do homem, necessidades estas que se expressam eminentemente mediante a participação. Ela possui papel preponderante na construção de uma sociedade democrática.

Contudo, "a democracia deve ser um estado de espírito e um modo de relacionamento entre as pessoas. Democracia é um estado de participação" (Bordenave, 1992:8).

Nessa perspectiva a participação popular e a descentralização das decisões mostram-se como caminhos mais adequados para enfrentar os problemas graves e complexos dos países em desenvolvimento.

"A participação disseminada em associações e entidades equilibraria a tendência
para a ruptura contida na participação se canaliza exclusivamente através dos
partidos políticos. Além disto, à medida que expressa interesses reais e mais
próximos e visíveis por cada um, ajudaria a conter a tendência inata para o
despotismo supostamente contido em toda democracia, já que ela sempre
contempla os interesses das maiorias e submete as minorias" (Bordenave,
1992:14).

Neste enfoque, a participação consiste não mais na recepção passiva dos benefícios da sociedade, mas na intervenção ativa na sua construção, o que é feito através da tomada de decisões e das atividades sociais em todos os níveis.

Com isso, ela não tem o caráter "consumista" atribuído pela vertente neoliberal, mas o de processo coletivo transformador, às vezes contestatório, no qual os setores marginalizados se incorporam à vida social por direito próprio e não como convidados, conquistando uma presença ativa e decisória nos processos de produção, distribuição, consumo, vida política e criação cultural.

"De modesta aspiração a um maior acesso aos bens da sociedade, a participação fixa-se o ambicioso objetivo final de" autogestão ", isto é, uma relativa autonomia dos grupos populares organizados em relação aos poderes do Estado e das classes dominantes. Autonomia que não implica uma caminhada para a anarquia, mas, muito pelo contrário, implica o aumento do grau de consciência política dos cidadãos, o reforço do controle popular sobre autoridade e o fortalecimento do 
grau de legitimidade do poder público quando este responde às necessidades reais da população" (Bordenave, 1992:20).

Este enfoque deflagra uma abordagem transformadora e baseada na coletividade, exercendo influência nos processos educativos que, de um caráter meramente "integrador", passam a ter caráter conscientizador e liberador.

Do ponto de vista neoliberal, a participação garante o controle das autoridades por parte do povo, visto que as lideranças centralizadas podem ser levadas facilmente à corrupção e à malversação dos fundos.

Nesse sentido, os mecanismos adotados pelos sistemas não buscam a superação de formas de participação reducionistas e controladas que obedecem a interesses minoritários. Eles estão atrelados a estruturas de poder, sendo passíveis de conflitos sociais.

Observa-se, através de estudos, que a participação, nesse enfoque, é considerada como uma simples relação humana ou um conjunto de "truques" para integrar os indivíduos e as coletividades locais nos programas de tipo assistencial ou educativo, contribuindo para o processo de minimização do papel do Estado.

Nessa perspectiva, a participação é utilizada como técnica para obtenção de coesão e de consenso. Reduz-se a um canal legítimo de manutenção do "status quo", servindo como mantenedora da relação entre dominantes e dominados, na qual está presente a premissa da exclusão.

Por outro lado, tem-se a democracia participativa que visa propiciar condições para que a comunidade participe nas questões administrativas, pedagógicas e financeiras, a fim de que, deste modo, melhore a qualidade da escola pública.

Segundo Vitor Paro, à medida que se conseguir a participação de todos os setores da escola - educadores, alunos, funcionários e pais - nas decisões sobre seus objetivos e funcionamento, haverá melhores condições para pressionar os escalões superiores e dotar a escola de autonomia e de recursos (Paro,1997). É preciso que haja condições materiais, institucionais, político-sociais e ideológicas propiciadoras dessa participação.

Com isso Paro classifica e caracteriza as determinantes da participação presentes na comunidade, com base em estudo de caso do cunho etnográfico, em:

Os condicionantes materiais de participação referem-se às condições objetivas em que se desenvolvem as práticas educativas. Com isso, a falta de tempo, o cansaço, 
a falta de local e espaço para as reuniões e discussões dos problemas ligados à escolarização dos filhos são elementos deste condicionante.

O autor argumenta que, por outro lado, não podemos acreditar que as condições materiais ótimas irão garantir uma democracia participativa, muito embora não possamos ignorar que a ausência dessas condições pode contribuir para o retardamento de mudanças que favoreçam o estabelecimento de canais de participação. Outro cuidado a ser tomado é não se utilizar das dificuldades materiais como desculpa para não fazer nada na escola.

Paro propõe dispositivo constitucional que facilite a importância da participação dos pais por meio da isenção de horas de trabalho no emprego. Para isso, é necessário que os movimentos populares e trabalhistas comecem a incluir em sua pauta de reivindicações, formas de pressão sob seus representantes no congresso, por meio de sindicatos, partidos políticos e demais instituições e mecanismos da sociedade civil.

Os condicionantes ideológicos estão relacionados à visão da população sobre a escola e sobre a participação.

"Por condicionantes ideológicos imediatos da participação estamos entendendo
todas as concepções e crenças sedimentadas historicamente na personalidade
de cada pessoa e que movem suas práticas e comportamentos no
relacionamento com os outros. Assim, se estamos interessados na participação
da comunidade na escola, é preciso levar em conta a dimensão em que o modo
de pensar e agir das pessoas que aí atuam facilita/incentiva ou dificulta/impede a
participação dos usuários" (Paro, 1997:47).

Percebe-se que a omissão dos pais soa como uma resposta à omissão da própria escola em suas obrigações. A população preocupa-se, a seu modo, com a qualidade da escola pública (merenda, falta de professores, segurança) não tendo atentado, ainda, para a importância de sua participação na escola. Pode ser em razão de nossa tradição autoritária e de não-participação social, além do equívoco do ensino ser percebido como mercadoria e o aluno como consumidor. Além disso, os pais das camadas populares sentem-se constrangidos em relacionar-se com pessoas de escolaridade, de nível econômico e status social acima dos seus, com receio de represálias contra seus filhos.

Tem-se observado que a ajuda dos pais na execução de festas e outros acontecimentos na escola são considerados como participação. Entretanto, a participação da comunidade na escola não elimina a participação na execução, mas 
não se deve tê-la como fim e sim como meio, quando necessário, para a participação propriamente dita, que é a partilha do poder.

\begin{abstract}
"A questão da participação na execução envolve ainda uma importante contradição que parece comum no discurso dos que se põem contra a participação da população na gestão da escola pública. Trata-se da pretensão de negar legitimidade à participação dos usuários na gestão do pedagógico, por conta do aludido baixo nível de escolaridade e da ignorância dos pais a respeito das questões pedagógicas, ao mesmo tempo em que se exige que os mesmos pais participem (em casa, no auxílio e assessoramento dos seus filhos) da execução do pedagógico, quando o inverso nos pareceria razoável" (Paro, 1997:52,grifos meus).
\end{abstract}

O suposto, detectado na pesquisa do autor, de que a população possui baixa escolaridade e desconhece o funcionamento formal da escola não deveria servir de argumento para afastar a comunidade da escola, com a alegação de que os pais não têm condições técnicas de participar da gestão da escola. Esse suposto reforça a redução da gestão escolar a elementos estritamente técnicos, quando a contribuição da comunidade é de caráter, principalmente, político.

Os condicionantes institucionais dizem respeito ao caráter hierárquico da distribuição de autoridade submetido a relações verticalizadas o que inviabiliza ou dificulta formas de participação que fazem com que o poder de decisão seja coletivo e pautado na horizontalidade das relações.

Mesmo sabendo que têm direito ao ensino público e gratuito há pais que concordam em pagar taxas de APM, porque vêem nessa medida as únicas alternativas que a escola thes apresenta para que possa funcionar minimamente. Com isso, instalase uma descrença na possibilidade de se organizarem e lutarem por essa conquista em longo prazo, optando por soluções parciais, de curto prazo, mas que julgam possíveis de concretizar. A própria postura das lideranças dos movimentos sociais é contraditória, pois elas se mostram afirmativas na concretização dos seus direitos de cidadania e apáticas diante da questão da participação na escola.

Nos condicionantes político-sociais, estando em jogo os interesses dos grupos dentro da escola, pode-se considerar que os atores escolares (professores, alunos, funcionários) são orientados por seus interesses imediatos e, por conseqüência da diversidade dos interesses dos grupos que se relacionam no interior da escola, estes são conflituosos.

"Na perspectiva de uma participação dos diversos grupos na gestão da escola, parece que não se trata de ignorar ou minimizar a importância desses conflitos, mas de levar em conta sua existência, bem como suas causas e suas implicações na busca da democratização da gestão escolar, como condição necessária para a 
luta por objetivos coletivos de mais longo alcance como o efetivo oferecimento de ensino de boa qualidade para a população" (Paro, 1997:47).

Licínio Lima, explorando a teoria de Paulo Freire, defende uma proposta de pedagogia democrática, de educação para e pela democracia, através de práticas dialógicas e antiautoritárias e do exercício da participação, voltada para a decisão e contrapondo-se à passividade.

"Na esteira da democracia como participação (ou democracia participativa), a participação, a discussão e o diálogo são apontados como verdadeiros métodos da construção democrática. Não é possível transitar da "consciência ingênua" para o processo de "conscientização" e para o exercício da "consciência crítica" a não ser pela participação crítica e da "verdadeira participação" " (LIMA, 2000:32).

A participação configura o elemento-chave para a construção de uma sociedade democrática, já que é através do seu exercício, no âmbito reduzido e tendo como essência a coletividade, que se pode conquistar autonomia (pedagógica, financeira e administrativa) e criar e operacionalizar medidas descentralizadoras, assegurando, assim, a partilha do poder e o subsídio, em âmbito amplo, para a participação social. 


\subsection{DESCENTRALIZAÇÃO}

A descentralização é entendida, segundo Souza (2002), como estratégia para galgar a democratização da educação formal. Começou a ser incentivada de forma mais enfática ainda na década de 80 , por meio da política educacional expressa nos Planos Nacionais e Setoriais de Desenvolvimento, ao propor a descentralização da educação, tanto para ampliação das oportunidades educacionais, quanto para a melhoria da gestão. Contudo, apenas a partir das medidas legais implementadas nos anos 90s, particularmente a partir do Plano Decenal de Educação (1993), é que se percebeu o aprofundamento dessa tendência, confirmado pela LDB 9.394/96, cujo art. $3^{\circ}$. prevê a gestão democrática como um dos princípios do ensino público.

\subsubsection{A DESCENTRALIZAÇÃO DO ESTADO: PERSPECTIVA HISTÓRICA}

A descentralização opera-se dependendo das circunstâncias, em vários graus, de uma escala de intensidade que vai dos poderes puramente administrativos até a capacidade normativa e o status de autonomia.

Contudo, há que considerar e compreender as circunstâncias históricas em que - Brasil, e especificamente a educação brasileira abrigou a necessidade de descentralização do Estado brasileiro.

Desde seus primórdios, a vastidão de seu território, sua exploração baseada em capitanias independentes umas das outras, as origens culturais e miscigenações raciais diversas de seus núcleos de povoamento, suas diferenças geofísicas e climáticas engendraram os particularismos regionais do Brasil e o desejo concomitante de descentralização política.

Com a proclamação da Independência, em 1822, D. Pedro definiu, junto com a constituinte, que o governo seria monárquico, hierárquico, hereditário, constitucional e representativo. Mas escolhe uma forma unitária de Estado. Ferido na sua soberania pela intervenção do Imperador e decepcionado pela imposição do centralismo, o povo adota uma atitude de oposição a D. Pedro, que acaba abdicando em 1831. Em 1834, durante a Regência, um Ato Adicional à Constituição concede personalidade às províncias que, em seguida, adotam assembléias constituintes autônomas. 
A partir de 1840 o governo volta, aos poucos, a um regime de centralismo rígido que acaba atraindo contra si a ira popular. Em 1889, com a proclamação da República, o primeiro decreto provisório do governo afirma que os laços federativos agremiam as ex-províncias as quais constituem, a partir de então, os Estados Unidos do Brasil. Configura, contudo, um passo "descentralizador" na história política de nosso país. Entretanto, de uma repartição de competências em duas esferas separadas, uma da União e outra dos Estados-Membros, passou-se, em poucas décadas, a uma repartição vertical de competências que implicou a coordenação das duas esferas, sob a orientação da União.

Esse novo federalismo coorporativo que atribui a mesma matéria, em níveis diferentes, à União e aos Estados-Membros, a primeira definindo as normas gerais e os últimos cuidando dos detalhamentos, toma um novo impulso com a Revolução de 30 e o Estado Novo.

Inicia-se uma retomada para o centralismo por conseqüência da pobreza de alguns estados que não dispõem de recursos suficientes para desempenhar os papéis que lhes cabem por conta de sua autonomia e dos pedidos de ajuda à União, cujo poder se vê assim reforçado.

A partir do golpe militar de 64, a centralização é tão acentuada que o país toma feições de um Estado unitário, até mesmo por influência do militarismo.

Na Constituição de 1988 definiu-se o Estado como

“... uma federação orgânica, de poderes superpostos, na qual os EstadosMembros devem organizar-se à imagem e semelhança da União; suas constituições particulares devem espelhar a constituição federal, inclusive nos seus detalhes de ordem secundária; e suas leis acabam subordinadas... ao princípio da hierarquia" (Scheinowitz, 1992:405).

Tenta-se um reequilíbrio da federação pela afirmação da autonomia dos estados e municípios. Reza o artigo 18 da Carta Magna que "A organização políticoadministrativa da República Federativa do Brasil compreende a União, os Estados, o Distrito Federal e os Municípios, todos autônomos, nos termos desta Constituição" (Scheinowitz, 1992:405).

Sabemos, entretanto, o quanto a autonomia assegurada na Constituição fica limitada por falta de poder de decisão financeira e deliberativa a partir das necessidades regionais. Aliás, foi por esse motivo que, a partir de 30 , os estados praticamente abdicaram de sua autonomia em nome da insuficiência financeira. $O$ 
que fazer com uma autonomia decretada que, no momento de sua operacionalização, carece dos recursos necessários?

Em meio a este contexto e a esta tendência à descentralização, o governo federal lançou, logo após a promulgação da Carta, o Projeto Desmonte, que visava repassar algumas de suas obrigações aos estados e municípios do país.

Percebe-se, então, a constatação da hipótese de utilização da descentralização como processo de desresponsabilização do Estado diante das outras esferas visando-se a desconcentração de tarefas, não de poder deliberativo, com os estados e municípios ${ }^{19}$. Em 1983, o governo do Estado de São Paulo proclamava que

“... aquilo que o Estado puder fazer melhor do que a União deve ser feito no Estado. Aquilo que o Município puder fazer melhor que o Estado deve ser feito pelo Município. Aquilo que a comunidade puder fazer melhor do que o Município deve ser feito pela comunidade" (Scheinowitz, 1992:406).

Isso demonstra uma perspectiva descentralizadora reduzida a tarefas, embasada em práticas paternalistas e clientelistas, faltando atribuir autonomia aos âmbitos financeiros e administrativo-normativos.

\footnotetext{
${ }^{19}$ Explica Scheinowitz (1992:410): "trata-se de uma estrutura que representa um meio-termo entre descentralização e desconcentração, já que o grosso dos recursos que Ihe são necessários é oriundo de Brasília. A descentralização significa responsabilidade e não há real responsabilidade sem os recursos que a fortalecem".
} 


\subsubsection{A DESCENTRALIZAÇÃO DA EDUCAÇÃO NO CONTEXTO DA LDB 9.394/96}

No contexto da lei 9.394/96 criaram-se os sistemas de ensino, que serão federal, municipal e estadual, tendo cada sistema sua competência e atribuição específica. A união terá como atuação prioritária a educação superior e a ação supletiva e redistributiva. Será responsável juridicamente pelas instituições federais de ensino, instituições de educação superior privadas e órgãos federais de educação. Terá a incumbência de: a) elaborar o Plano Nacional de Educação, b) administrar o Sistema Federal de Ensino, c) dar assistência técnica e financeira aos municípios, d) elaborar as diretrizes curriculares nacionais, e) criar e gerenciar o Sistema de Informações e de Avaliação Educacional. (Vemos, contudo, um controle de qualidade proposto, sem que sejam asseguradas as condições necessárias para que essa qualidade se efetive).

Aos estados compete, como atuação prioritária, o ensino fundamental e o ensino médio. Deve, portanto, responder juridicamente pelas instituições estaduais de ensino, pelas instituições de ensino superior municipais, pelas instituições de ensino fundamental e médio privadas e pelos órgãos estaduais. Deverão incumbir-se de: a) manter e organizar o sistema de ensino, b) colaborar com o ensino municipal, e c) elaborar planos educacionais integrando as ações dos municípios.

Aos municípios caberá, como ação prioritária, a educação infantil, o ensino fundamental e a educação dos jovens e adultos. Responderá juridicamente pelas instituições municipais de educação. Deverá incumbir-se de: a) administrar o sistema municipal de ensino, b) autorizar, credenciar e supervisionar as escolas e c) colaborar com o Estado.

Desta forma, a educação básica ficou composta pela educação infantil, pelo ensino fundamental e ensino médio.

A educação profissional e a educação superior não fazem parte obrigatória de nenhum destes sistemas de ensino. E aqui se abre amplamente o campo para o crescimento das iniciativas privadas, limitando-se o acesso e/ou expansão destes níveis de ensino.

A desigualdade estrutural na oferta dos níveis de ensino ficou amplamente consagrada, mantendo o ensino profissional médio e superior fora da obrigatoriedade ${ }^{20}$ da oferta pelo Estado, uma vez que estes níveis de ensino não são obrigatoriamente

\footnotetext{
${ }^{20} \mathrm{~A}$ obrigatoriedade foi atribuída apenas em relação ao ensino fundamental.
} 
ofertados por nenhum sistema (federal, estadual ou municipal), o que indica que nos próximos anos serão ainda mais reduzidas ou até deixarão de existir redes públicas destes níveis de ensino. No caso da educação profissional, as iniciativas poderão ser as mais variadas como, por exemplo, experiências comunitárias, organizações nãogovernamentais, cursos organizados por empresas, criação de escolas técnicas privadas, entre outras.

Nesta organização de ensino proposta pela LDB, percebemos o quanto a descentralização e/ou re-centralização de responsabilidades, devidamente fragmentadas entre os níveis municipais, estaduais ou federal, seguem prontamente as orientações do Banco Mundial.

"A descentralização da prestação de serviços_transferindo recursos a níveis mais baixos de governo _ é outro meio potencialmente poderoso de introduzir pressões competitivas internas, principalmente na provisão de bens públicos locais" (Banco Mundial, 1997, p. 95 apud. Adrião, 2001).

Esclarece Oliveira (1999) que o debate concentra-se em questões como concepção de gestão do sistema escolar, distribuição de responsabilidades entre os diferentes níveis da administração pública, e transformação das escolas em unidades autônomas que, no longo prazo, podem ter o sentido de privatização, mas que, no curto prazo, apresentam, como característica mais importante, a redução do suporte estatal e o fortalecimento de formas privadas de financiamento do sistema educacional. 


\subsubsection{DESCENTRALIZAÇÃO COMO ESTRATÉGIA NEOLIBERAL}

A descentralização da educação, apresentada pelos discursos oficiais -nacional e internacional- como uma tendência moderna dos sistemas educativos mundiais, tem sido não só um objetivo preferencial das políticas na área, produzidas a partir da década de 80 , como também tem dado coesão ao conjunto das políticas educacionais nas últimas duas décadas.

Apesar de a descentralização não ser intrinsecamente democratizante, é corrente a confusão conceitual sobre o tema ligando centralização a autoritarismo e descentralização a democracia.

Entre as diferentes dimensões da descentralização adotadas nos sistemas pedagógica, administrativa e financeira - esta última é a forma prevalente. No entanto, a precariedade de recursos faz com que a descentralização financeira transforme-se em administração da escassez, funcionando como fator agravante o fato de a escola, tida pelo sistema como autônoma, ver-se obrigada a decidir sobre a sua própria privação.

Essas medidas fazem parte de um movimento de globalização-descentralização, configurando um modelo de gestão dos sistemas educacionais que tende à atomização dos espaços institucionais e à delegação de competências ao setor privado.

Afirma-se que a descentralização entre os diferentes órgãos de governo permite direcionar os gastos públicos a alvos específicos, otimizando os investimentos na melhoria do ensino fundamental; aumenta as possibilidades de interação, no nível local, dos recursos públicos, dos não-governamentais e dos privados para o financiamento dos programas sociais e permite responder melhor e com mais rapidez às necessidades e demandas dos usuários, devido à proximidade entre os problemas e a gestão. Entretanto, nos moldes neoliberais em que vem sendo implementada a descentralização, há uma redefinição estratégica, que não representa uma unidade de força política coesa, mas sim, competições entre as diferentes esferas de poder e a realização de ações para fortalecimento de sua hegemonia. A descentralização pode significar, de acordo com Rosar (1997): (a) possibilidade de aumentar a participação não dos indivíduos em geral, mas de determinados grupos e indivíduos; (b) deslocamento do poder do governo central para os governos locais que permita garantir a hegemonia dos grupos que detêm o seu controle; (c) em outras situações 
possibilidade de deslocamento de uma instituição centralizada para outra também centralizada; e (d) em outras, deslocamento do poder do governo para o setor privado.

Essas possibilidades evidenciam que, na realidade, as políticas governamentais definem-se como resultado de uma luta e que, portanto, não há consenso nem mesmo entre as facções do bloco político no poder. Além disso, as políticas de descentralização podem ser utilizadas por um grupo central minoritário para desequilibrar a correlação de forças em uma comunidade local, em favor de grupos que apóiam o grupo central dominante ${ }^{21}$.

Pesquisas realizadas no Brasil demonstram o espírito focalista, fragmentário e privatista da reforma do Estado, pela falta de compromisso da União, de redução do financiamento público para a educação e da influência das condições de desenvolvimento dos municípios que pouco têm a ver com a organização territorial e política dos mesmos.

Para Bresser Pereira, a saída para a recuperação da legitimidade foi encontrada na administração pública gerencial, definida como aquela que se inspira nos avanços realizados pela administração de empresas, caracterizados por: a) descentralização do ponto de vista político, transferindo-se recursos e atribuições para os níveis políticos regionais; b) descentralização administrativa, através da delegação de autoridade aos administradores públicos, transformados em gerentes cada vez mais autônomos; c) organizações com poucos níveis hierárquicos, ao invés de piramidais; d) controle a posteriori, ao invés do controle rígido, passo a passo, dos processos administrativos; e f) administração voltada para o atendimento do cidadão, ao invés de auto-referida (Bresser Pereira, 1999:242; apud: Oliveira, 2002:126).

A descentralização, como orientação para o planejamento, já estava prevista na reforma do Estado na década de 60. Nos anos 90s, como podemos perceber, através da intervenção do MARE dirigido por Bresser Pereira, ganha novo vigor e caráter, sendo apresentada como estratégia administrativa e tendo como eixo a flexibilização e desregulamentação da gestão pública, com a justificativa de busca de melhoria no atendimento ao cidadão/contribuinte, reduzindo mediações.

De acordo com Dalila Andrade de Oliveira (2002), podemos considerar que o processo de descentralização começa a ocorrer, sobretudo a partir da tentativa de

\footnotetext{
${ }^{21}$ Os grupos que detêm o poder utilizam estratégias de centralização ou de descentralização com o objetivo de que essas políticas possam atender aos seus interesses e aos dos grupos com os quais tenham feito aliança.
} 
municipalização, defendida como a possibilidade de permitir às populações maior controle sobre a gestão das políticas públicas pela proximidade física com os meios de decisão e gestão das mesmas.

"As reformas educacionais dos anos 90 trarão, então, a marca da
descentralização que resultou em maior autonomia das escolas, porém teve como
contrapartida uma sobrecarga de trabalho administrativo sem a real
correspondência em termos de condições de infra-estrutura nos estabelecimentos
de ensino. Sob o argumento da necessidade de conferir maior autonomia às
unidades escolares, os órgãos centrais do sistema acabaram por delegar às
escolas muitas das suas rotinas administrativas" (Oliveira, 2002:130).

Antônio Lisboa Leitão de Souza (2002), citando Oliveira (2000), apresenta diferentes concepções e estratégias descentralizadoras, dependendo dos interesses que estão em jogo, sendo possível classificá-las em:

"(a) desconcentração, entendida como delegação de responsabilidades
administrativas às esferas inferiores dentro da instância governamental; b)
transferência de responsabilidades a organizações ou entidades que atuam fora
do governo, mas ficando controladas indiretamente por este; c) devolução de
unidades administrativas governamentais, cujas atividades estão fora de controle
direto do governo central; d) privatização de atividades e serviços públicos
avaliados como não mais de competência estatal e repassadas à iniciativa
privada" (p.97-8).

Maria de Fátima Félix Rosar (1997) demonstra, em seus estudos, que a descentralização proposta está adequada ao fortalecimento do projeto político da burguesia nacional e internacional, que a operacionaliza, principalmente, através da municipalização como estratégia de incorporação de grupos e de processos de organização convergentes ao paradigma neoliberal.

"A finalidade última desse processo é a construção de um equilíbrio das forças políticas que atuam na sociedade, de modo a conter as condições subjetivas para a elaboração de um projeto alternativo para a sociedade" (Rosar, 1997:136).

Isso demonstra o quanto a descentralização está articulada ao processo de globalização que ocorre tanto no âmbito econômico quanto no âmbito da difusão da ideologia neoliberal, cujas implicações têm sido, em última instância, contribuir para a desconstrução dos estados nacionais e dos seus sistemas educacionais, ocasionando fragmentação na base do sistema escolar e, entre outros prejuízos ao processo de democratização do ensino público, dificultando a articulação entre as escolas. 


\subsubsection{A DESCENTRALIZAÇÃO ATRAVÉS DE MUNICIPALIZAÇÃO}

De acordo com Romualdo Portela (1997), a utilização da expressão "municipalização de ensino" tem-se relacionado com a discussão em torno das competências das diferentes esferas da administração pública para com a educação e, de forma mais geral, com o papel do Estado em garantir educação para toda a população. Ela pode ser entendida das seguintes maneiras: a) como iniciativa do poder municipal de ampliar o atendimento por parte desta esfera da administração pública; b) como processo de transferência de rede de ensino de um nível da administração pública para outro (geralmente do estadual para o municipal).

A municipalização é apontada por vários autores como uma forma possível de superação do centralismo, sendo utilizada como estratégia descentralizadora por alguns sistemas de ensino. No entanto, a abordagem da descentralização por via da municipalização pode ser apontada como restritiva, porque pode limitar a discussão sobre gestão educacional aos seus aspectos formais, pouco ou nada acrescentando às questões como a ampliação de processos participativos ou a alteração nas estruturas de poder.

De acordo com Rosar (1997), o processo de descentralização pela via da municipalização, induzida pelo governo federal, produziu um efeito desagregador das redes municipais, afetando diretamente a expansão e a qualidade do ensino. Para ela a política de descentralização favoreceu a concentração de recursos e de poder sob o controle dos mesmos grupos econômicos e políticos que se associam entre si em todos os níveis e setores da estrutura da sociedade capitalista.

\footnotetext{
"Nessa linha de análise, é de fundamental importância que o município seja compreendido como parte constituinte de um sistema maior. Portanto, somente a articulação nacional dos municípios numa perspectiva progressista poderá possibilitar o estabelecimento de uma correlação de forças mais favorável ao atendimento das prioridades educacionais definidas num Plano Nacional de Educação. Isto significa, portanto, que a estrutura e o funcionamento de um sistema nacional de educação estão compreendidos no âmbito das lutas políticas e que compete aos educadores potencializá-las no atual momento da conjuntura brasileira" (Rosar, 1997:139).
}

A autora argumenta, ainda, que a descentralização pela via da municipalização é utilizada como estratégia de incorporação de grupos e de processos de organização aos contornos do paradigma liberal. Na realidade, essa forma de atuação também dificulta o questionamento dos poderes políticos locais, à medida que dilui as diferenças 
e as possibilidades de oposição a projetos de caráter genericamente democrático. A finalidade última desse processo é a construção de um equilíbrio das forças políticas que atuam na sociedade, de modo a conter as condições subjetivas para a elaboração de um projeto alternativo para a sociedade. 


\subsubsection{A DESCENTRALIZAÇÃO NA ESCOLA E SUA RELAÇÃO COM AUTONOMIA}

A proposta de descentralização para a escola por meio da política da autonomia iniciou-se na década de 80 , no contexto de luta pela consolidação do sistema democrático, no qual a atenção na gestão escolar voltou à cena como parte de um debate político mais amplo em torno do direito de participação da sociedade civil como condição de uma cidadania ativa. Nesse contexto, a gestão colegiada da escola era vista como a forma mais adequada para transformar a lógica da autoridade e do exercício do poder na escola e no sistema educativo, gerando espaços de autonomia institucional e de participação.

A política de descentralização para a escola reposiciona a instituição escolar e o Estado na produção político-educacional. Nessa nova lógica de organização do sistema educativo, busca-se instaurar dispositivos e ações na gestão/ governo institucional orientados pelos princípios de flexibilidade, liberdade, diversidade, competitividade e participação.

Busca-se, por meio da política de autonomia escolar hegemônica, a ampliação da liberdade de decisão e a gestão institucional dos recursos materiais e financeiros para dinamizar e otimizar a prática escolar, e a flexibilização das diretrizes para permitir a produção em equipe de um projeto pedagógico institucional direcionado para objetivos que tenham significado para seus usuários.

Os princípios da gestão escolar têm sua origem na mudança do modelo de gestão da produção material do fordismo para o de Qualidade Total (modelo toyotista de produção). Esse último, também denominado de "Gestão Participativa", dá ênfase à importância do trabalho em equipe e da extensão das responsabilidades, mas ressalta, de modo especial, a liderança da gestão.

O pressuposto da proposta de gestão da Qualidade Total é que quanto mais claro seja o entendimento que as pessoas tenham das organizações que integram, e quanto maior o "poder decisório" e o compromisso delas com os objetivos da instituição/empresa, maior a produção e melhor o produto. Em linhas gerais, buscase a cumplicidade do trabalhador individualizado, por meio da participação, e o compromisso considerados elementos-chaves no êxito de uma gestão. 
Outro de seus pressupostos é que uma boa gerência é a alma do êxito institucional. Isso vem sendo reforçado por várias ações governamentais que reproduzem a concentração de poder e responsabilidades na figura do diretor e, principalmente, intensificam seu caráter administrativo e tecnocrático, em detrimento de seu caráter de educador.

$\mathrm{Na}$ passagem do âmbito empresarial para o escolar, e no marco da reconfiguração do papel do Estado na provisão e na regulação educacional, afirma-se que uma escola autônoma é aquela que tem maior liberdade ${ }^{22}$ de organização, gestão e ação. A liberalização da gestão escolar estaria garantindo 0 aumento da responsabilidade de seus atores e, portanto, a eficiência da instituição. Essa idéia de liberdade na gestão surge como possibilidade ao serem suprimidas as ações governamentais, o que obriga as instituições a se tornarem "autônomas" na perspectiva Compartilhada e/ou da Qualidade Total.

Essa proposta de liberdade e autonomia está amparada na idéia de poder de justiça que o senso comum costuma the outorgar: poder para fazer o que considera melhor (para elaborar seus próprios projetos) e premiação ao esforço pessoal (ou institucional). $\mathrm{E}$ quando os efeitos desejados não se produzem, o fracasso é interpretado como fracasso pessoal dos atores da escola, tirando do Estado qualquer tipo de responsabilidade na gestão dos problemas educacionais.

Ocorre, contudo, a descentralização de responsabilidades, mantendo-se centralizado o controle através de mecanismos avaliativos.

Uma verdadeira descentralização, além de outros significados, deve criar sentido de projeto, de identidade institucional e desenvolver capacidade de gestão radicada dentro dos próprios centros educacionais.

\footnotetext{
${ }^{22}$ Segundo Naura Rut Krawczyk (2002:66), essa concepção de liberdade, "acunhada pela matriz liberalconservadora, foi qualificada, no interior do próprio liberalismo, como uma concepção negativa e regressiva, porque é individualista e encontra sua plena realização na redução ao mínimo possível do poder coletivo e estatal".
} 


\title{
4.3 AUTONOMIA
}

O conceito de autonomia foi construído historicamente pelas diferentes características culturais, econômicas e políticas que configuraram a sociedade ao longo de sua trajetória. Ele aparece na literatura acadêmica, em alguns casos vinculado à idéia de participação social e, em outros, vinculado à idéia de participação política no que tange a questões de descentralização e desconcentração de poder.

Etimologicamente esse conceito denota liberdade e poder de autodeterminação de conduta. Poder de criação das leis que seguirá e às quais poderá se submeter.

Cattani (1997) demonstra como o conceito de autonomia engloba uma vasta gama de valores e de experiências sociais ao longo da história.

\footnotetext{
"Para que lei e liberdade possam estar associadas, é necessário distinguirem-se as boas leis das más. As primeiras são estabelecidas pelos e para os sujeitos livres; as segundas são meio de opressão dos fortes sobre os fracos. A autonomia aparece, então, não como a capacidade de se agir segundo a lei, mas de se definir a própria lei" (Cattani, 1997:27).

"O principio geral autonomista contrapõe-se à lógica autoritária, ao poder decisório e discricionário empresarial ou estatal-burocrático. Opõe-se, também, ao colaboracionismo ou participacionismo promovido e controlado pelas elites" (Cattani, 1997:28).
}

Os grupos relativamente autônomos que negociam interesses no seio da sociedade não distinguem exatamente os limites entre os seus interesses particulares e os interesses da nação em geral ou, em outras palavras, fica difícil encontrar um representante que não represente interesses particulares. Para eles, a autonomia é exatamente o que não é: lógica autoritária e participacionismo controlado, em que ela é relativa, pois, por meio dela, no fundo, a comunidade escolar apenas colabora com o governo, mas não decide sobre as políticas.

\begin{abstract}
"A autonomia compõe o imaginário libertário e impulsiona, de forma espontânea ou induzida, as reivindicações e as práticas que se opõem às normas arbitrárias, às hierarquias opressoras e à racionalidade produtivista privada. É seu corolário a apropriação coletiva, a descentralização, a participação consciente no processo produtivo, na vida em sociedade e na criação cultural" (Cattani, 1997:28).
\end{abstract}

Contudo, assim como no resto do mundo, o conceito de autonomia perdeu sua força como princípio político e social, a partir dos anos 90 s, sendo recuperado por uma visão, que não deixa de ser política, mas, principalmente, individualista.

"Transformou-se numa questão de mentalidade, como uma maneira de ser e não como uma forma de contrapor-se à organização elitista do poder na sociedade. 
Concebida não mais como um valor e como um referencial prático na luta contra a dominação, a opressão e as hierarquias, transformou-se numa estratégia de sobrevivência ou de adaptação às circunstâncias adversas" (Cattani, 1997:33).

Acrescentaria, ainda, que é seu corolário a superação da alienação dos trabalhadores, ou seja, uma vez que os indivíduos tenham consciência de todo o processo de produção material e espiritual, não são mais alienados e podem, portanto, autodeterminar-se. Os indivíduos autônomos podem fruir, viver, apropriar-se das riquezas produzidas socialmente, com determinação, compromisso e não-passividade. 


\subsubsection{O SIGNIFICADO DA AUTONOMIA NUMA LÓGICA NEOLIBERAL}

Ao lado de implementações arbitrárias e de discursos ambíguos, tem-se no diaa-dia das escolas uma constante deterioração das condições de trabalho dos educadores, o sucateamento das escolas e a ausência da definição de um ponto norteador para as políticas públicas capaz de reverter a realidade que se apresenta.

De um lado, o exercício da autonomia encontra-se reduzido à ampliação de espaços internos de discussão e limitado à liberdade da escola implementar projetos especiais que se resumem a atividades didáticas diferenciadas dentro de disciplinas que compõem o currículo. De outro lado, o Estado parece confiar nos resultados das negociações realizadas entre os profissionais da educação dependentes de seus próprios recursos, competências e empenho para executar as medidas políticas.

Há consenso sobre a necessidade de a escola ser autônoma, pois a construção e o exercício da autonomia incentivam o pluralismo de idéias, o respeito às diferenças e a emergência de atores sociais criativos e responsáveis. Porém, a idéia mágica de que bastam novas normas para que a gestão das políticas públicas mude seu padrãosacralizado na cultura político-administrativa das instituições- deve ser questionada.

Uma proposta de autonomia escolar exige um esforço descentralizador e desconcentrador de poderes e recursos. A priori, essas premissas são louváveis, conquanto sejam contextualizadas e imersas num conjunto de princípios comprometidos com os interesses da maioria da população. Entretanto, a descentralização e desconcentração e até mesmo a municipalização, como vias de atribuição de autonomia, estão sendo utilizadas para diluir o poder de blocos políticos oponentes, para otimizar recursos e diminuir a responsabilidade pública, para viabilizar uma política educacional privatizante e, com isto, uma chamada à comunidade para "participar" na escola de seus filhos.

Essa proposta de Estado pode ser enquadrada na denominação de Licínio Lima (2000) de autonomia monitorada. Pois o governo é que está controlando as instâncias deliberativas das escolas de maneira incisiva. Ou seja, é-lhes atribuída autonomia de decisão sim, muito embora a grande maioria é apenas de execução de tarefas preestabelecidas, mas ao mesmo tempo existe um processo de formação ${ }^{23}$ dessas

${ }^{23} \mathrm{O}$ processo de formação dos professores, equipe pedagógica, direção e membros das APMs das escolas, é feito em Faxinal do Céu, desde 1995, onde foi criada a "Universidade do professor". O 
instâncias para que deliberem e executem aquilo que o governo espera que seja deliberado e executado. É uma falsa autonomia e um requintado monitoramento de governo, porquanto estão conseguindo interiorizar nos gestores o discurso neoliberal de autonomia, de participação, de democracia. Aliás, em contraposição a estes conceitos, a autonomia escolar, que está sendo concedida, em momentos pertinentes, pelos grupos hegemônicos, jamais poderia ter sido imposta ou cobrada e sim conquistada a partir de princípios democráticos.

As referências à autonomia escolar nas legislações e normas dos sistemas de ensino são feitas de maneira vaga. De modo geral, enunciam a autonomia como um valor, mas não estabelecem mecanismos concretos para sua conquista efetiva, inclusive medidas de reestruturação burocrática que permitam o funcionamento dos órgãos hierarquicamente superiores, a partir das necessidades e projetos gerados pela escola. O próprio Regimento Escolar, expressão jurídica por excelência da unidade escolar, é um exemplo de sua falta de autonomia, visto que, na maioria dos casos, tem forma única estabelecida pelas administrações centrais e aprovadas pelos órgãos normativos dos sistemas, em flagrante desrespeito às características pedagógicas e culturais específicas de cada escola, na sua relação com as comunidades locais.

A proposta de autonomia do Estado estimula a participação dos pais e da comunidade na escola. Contudo, essa participação fica vinculada principalmente no tocante à arrecadação e à administração financeira. Nesse caso, a participação da comunidade na escola não é uma participação efetiva, de contribuição/ participação nas tomadas de decisão; quando muito a comunidade é comunicada sobre as decisões já tomadas, assumindo uma postura passiva diante das mais relevantes questões, como, por exemplo, a discussão e o encaminhamento de um projeto educativo cujos objetivos venham ao encontro de suas necessidades, isto é, que seja um projeto que promova a democratização do ensino. Um projeto que, por sua vez, não tenha como eixo principal a formação de mão-de-obra para o mercado de trabalho, mas sim que promova uma formação integral do indivíduo, uma formação que garanta o desenvolvimento também em seus aspectos sociais e políticos e contribua para a transformação da realidade.

A autonomia, de acordo com o exposto acima, deveria contribuir para a discussão de uma nova concepção de escola, de sujeito e de sociedade, uma vez que, garantida a participação da comunidade, essa deveria trazer para o interior da escola 
sua visão de mundo e contribuir para a construção de um projeto que contemple os interesses e as necessidades das camadas populares.

"Liberdade" individual para competir, buscar inovações capazes de reduzir custos, gerar recursos e produzir bons resultados, através do estabelecimento de parcerias_devendo (a escola) perseguir a excelência_ instrumento fundamental de construção de uma cultura de organização de empresa. 


\subsubsection{O SIGNIFICADO DA AUTONOMIA NUMA LÓGICA PROGRESSISTA}

Em contraposição, as concepções freirianas de democracia radical e de cidadania crítica conferem à autonomia um significado que põe em evidência a capacidade dos seres humanos produzirem juízos conscientes e livres, não influenciados nem distorcidos por relações assimétricas e por desigualdades sociais.

A autonomia da escola é algo que se põe com relação à liberdade de formular e executar um projeto educativo, com capacidade para identificar problemas, apresentar alternativas para solucioná-los e administrar os recursos financeiros consoantes com tais alternativas.

Podemos classificar a autonomia em gestão financeira, administrativa e pedagógica. Elas se inter-relacionam dialeticamente. A autonomia de gestão financeira efetivamente não existe, a não ser com o dinheiro alocado pela APM e através de parcerias com o setor privado lucrativo e/ou não-lucrativo. Pode-se perceber a ausência de autonomia da escola na destinação e no manuseio das verbas e na insuficiência dos recursos para fazer frente às necessidades de manutenção e de ampliação das atividades pedagógicas.

Quanto à autonomia pedagógica, ao mesmo tempo que se incentiva o exercício da autonomia escolar para elaboração coletiva de seu projeto pedagógico, estabelecem-se rigorosos procedimentos de organização e funcionamento das escolas. Como ter autonomia pedagógica quando faltam recursos para implementar atividades didáticas diferentes das que os professores adotam convencionalmente em sala de aula? Isso é uma forma de persuasão para que aceitem as mudanças propostas? Como querer implementar a autonomia de baixo para cima, se na própria formação dos educandos não thes são oferecidas possibilidades de desenvolvimento de autonomia moral e intelectual (Kamii), ou seja, se diante de problemas disciplinares de conduta as atitudes convergem para medidas autoritárias pautadas por rígida normatização da escola com base em castigo e prêmios? Outra questão relacionada à autonomia pedagógica diz respeito ao projeto político pedagógico da escola, que, defende-se, deve ser a "cara" da escola; mas existe um modelo a ser seguido e um controle avaliativo que asseguram que as escolas sigam a perspectiva do Estado.

No interior da sala de aula há que se criar condições propícias para que se desenvolva a autonomia moral e intelectual dos educandos, tentando-se romper com a 
cultura da submissão, mesmo que velada e com a cultura de segmentação entre o trabalho intelectual (os que planejam) e o trabalho manual (os que executam), exercitando-se o poder de decisão coletivo e consubstanciado no princípio de justiça.

\begin{abstract}
"A essência da autonomia é que as crianças tornem-se aptas a tomar decisões por si mesmas. Mas a autonomia não é a mesma coisa que a liberdade completa. A autonomia significa levar em consideração os fatos relevantes para decidir agir da melhor forma para todos. Não pode haver moralidade quando se considera apenas o próprio ponto de vista. Quando uma pessoa leva em consideração os pontos de vista das outras, não está mais livre para mentir, quebrar promessas e ser leviano" (Kamii, 1990:108).
\end{abstract}

A autonomia e a responsabilidade são, simultaneamente, condições e conseqüências da democracia, resultados alcançados por uma educação democrática e condições necessárias à prática dessa educação e ao processo de democratização da escola (Lima, 2000:83).

O projeto político pedagógico (PPP) é apontado como expressão coletiva do esforço da comunidade escolar na busca de sua identidade e, nesse sentido, como uma das principais expressões da autonomia escolar. A participação aliada à autonomia pode, mesmo, propiciar uma experiência mais conseqüente de outros mecanismos de gestão democrática, como a escolha dos dirigentes e a definição das funções dos colegiados escolares, à medida que passa a constituir-se referência da ação orgânica de todos os membros da comunidade escolar na busca de objetivos comuns.

A proposta é que a autonomia seja materializada na liberdade da escola em pensar seu projeto político-pedagógico e na liberdade do professor para introduzir inovações pedagógicas ao seu cotidiano de sala de aula. Percebe-se que o significado da participação da comunidade no processo de gestão e autonomia escolar reduz-se ao comprometimento financeiro da comunidade local para a manutenção da escola pública.

Com relação à autonomia administrativa pode-se dimensioná-la em fatores endógenos, que consistem em procedimentos administrativos institucionais, e em fatores exógenos, que consistem em ampliação de contatos com a comunidade escolar.

As medidas políticas da SEED e NRE são ordens sobrepostas enviadas por Diário Oficial, ou $\mathrm{Cl}$, ou outros documentos fragmentados e comandados pela lógica de uma organização burocrática ${ }^{24}$, alheia às demandas de alunos, professores, direção e comunidade. 
Segundo Ângela Maria Martins (2002), as graves questões advindas de intervenientes burocráticos podem estar menos relacionadas à dinâmica estabelecida por possíveis conseqüências de disfunção burocrática no seu sentido clássico, weberiano, do que à forte permanência de uma tensão constituída pela prevalecência de valores tradicionais, patrimonialistas, que configuram, uma cultura, na área, difícil de ser rompida.

Há uma tensão entre a autonomia de uma instituição, no caso a escola, e o conjunto das demais instituições sociais cuja função é garantir a reprodução das relações sociais de produção. Nesse sentido, seu exercício esbarra nos mesmos limites postos para os movimentos autônomos de trabalhadores, pois, de uma parte, não há a menor possibilidade de destruir as bases de sustentação da sociedade no espaço intraescolar, nem a cultura subjacente a ela; de outra, há uma inegável legitimidade desse espaço para a reflexão e ação necessárias sobre questões sociais e políticas que tanto afetam a escola.

Dentre os limites postos pelos mecanismos burocráticos e centralizadores ainda não-superados, destaque-se a reprodução, no cotidiano, das representações do universo político: de um lado, um Estado excessivamente normatizador e, de outro, atores razoavelmente vulneráveis às trocas político-administrativas e às mudanças permanentes nos planos, programas e projetos que se sucedem ou se sobrepõem. Nessas circunstâncias, a equipe pode seguir a direção com procedimentos que permitam sua aceitação no órgão mais próximo (NRE), já que diminuem as cobranças e a sensação de serem estigmatizados nas reuniões regionais. Ou, ao contrário, é possível que os atores envolvidos na operacionalização de medidas legais e normativas tenham condições de compreendê-las criticamente, avaliando coletivamente se irão dissimular seu cumprimento e, ainda, como irão implementá-las.

A partir das categorias participação, autonomia e descentralização, apresenta-se de forma simplificada e esquemática as principais diferenças entre a proposta de Gestão Compartilhada, consubstanciada no modelo de GQT, e a proposta de Gestão Democrática, no quadro II a seguir, considerando-se que, na realidade empírica, elas não ocorrem isoladamente ou sozinhas, ou seja, não é possível, diante de realidades complexas e contraditórias, encontrar escolas com atitudes unicamente compartilhadas ou unicamente democráticas. 


\section{QUADRO II: GESTÃO COMPARTILHADA E GESTÃO DEMOCRÁTICA: PARTICIPAÇÃO, AUTONOMIA E DESCENTRALIZAÇÃO.}

\begin{tabular}{|c|c|c|c|c|}
\hline & \multicolumn{2}{|c|}{ GESTÃO COMPARTILHADA } & \multicolumn{2}{|c|}{ GESTÃO DEMOCRÁTICA } \\
\hline & POLÍTICA EDUCACIONAL & ESCOLA & \begin{tabular}{|l|} 
POLITICACA \\
EDUCACIONAL \\
\end{tabular} & ESCOLA \\
\hline PARTICIPAÇÃO & 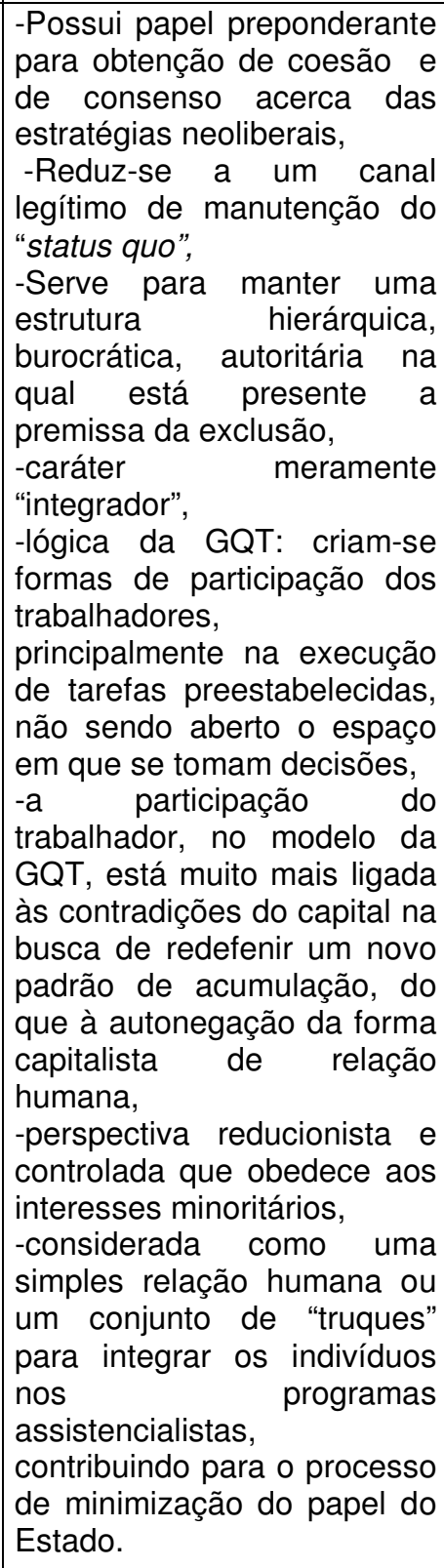 & 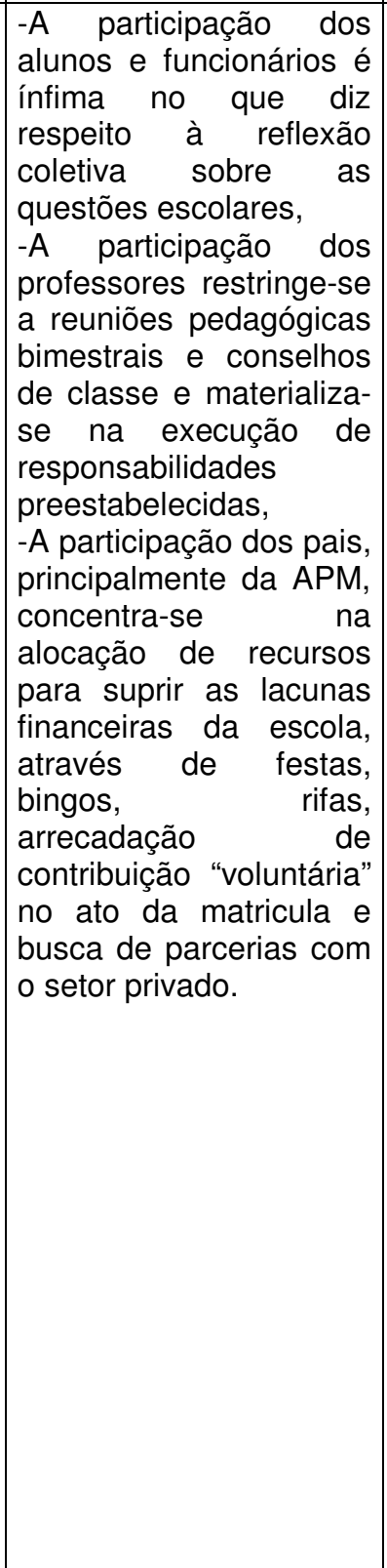 & 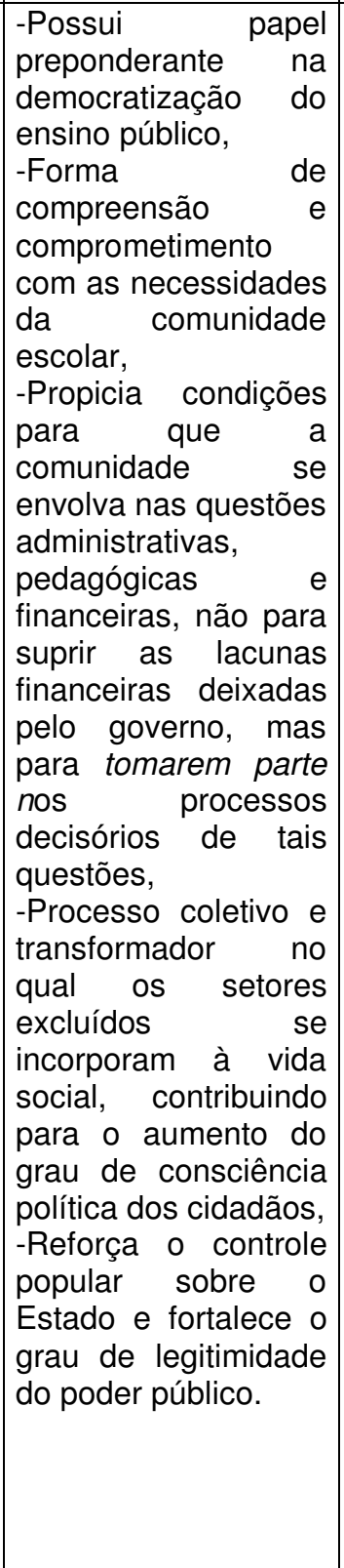 & 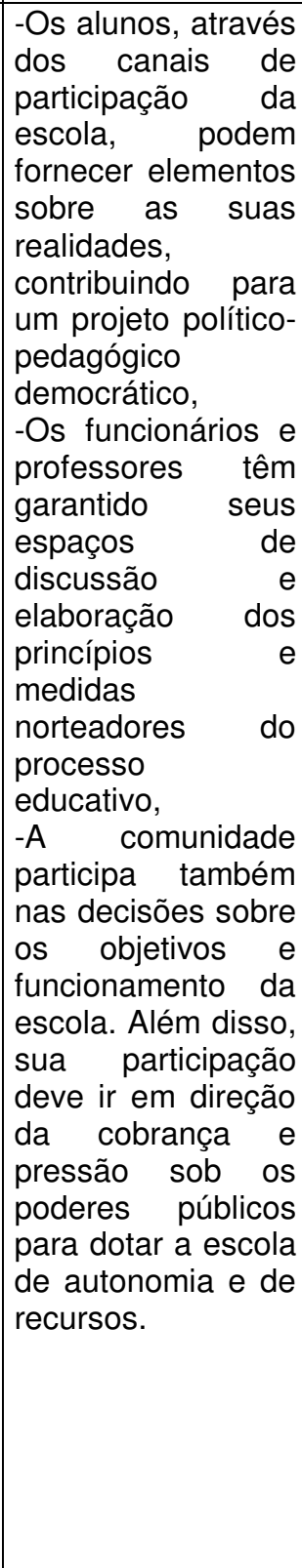 \\
\hline AUTONOMIA & $\begin{array}{l}\text {-"Liberdade" individual para } \\
\text { competir e buscar inovações } \\
\text { administrativas, financeiras e } \\
\text { pedagógicas, na } \\
\text { organização, gestão e ação } \\
\text { no interior das instituições } \\
\text { escolares, garantido } \\
\text { aumento } \\
\end{array}$ & $\begin{array}{lrr}- \text { - A escola } & \text { não } & \text { possui } \\
\text { autonomia } & \text { financeira, } \\
\text { pedagógica } & e \\
\text { administrativa, } & \\
\text {-Ela possui } & \text { autonomia } \\
\text { financeira } & \text { sobre a verba } \\
\text { alocada } & \text { por } & \text { vias } \\
\text { próprias } & \text { e, } & \text { mesmo } \\
\end{array}$ & $\begin{array}{|lr|}\text {-liberdade rerate } & \text { de } \\
\text { formular e executar } \\
\text { um projeto educativo, } \\
\text { com capacidade para } \\
\text { identificar e resolver } \\
\text { problemas } \\
\text { coletivamente com o } \\
\text { respaldo financeiro } \\
\end{array}$ & $\begin{array}{lr}\text {-necessidade de } \\
\text { ampliação dos } \\
\text { recursos escolares } \\
\text { por parte dos } \\
\text { poderes públicos, } \\
\text { sendo geridos } \\
\text { pelas instituições } \\
\text { escolares, de } \\
\end{array}$ \\
\hline
\end{tabular}




\begin{tabular}{|c|c|c|c|c|}
\hline & 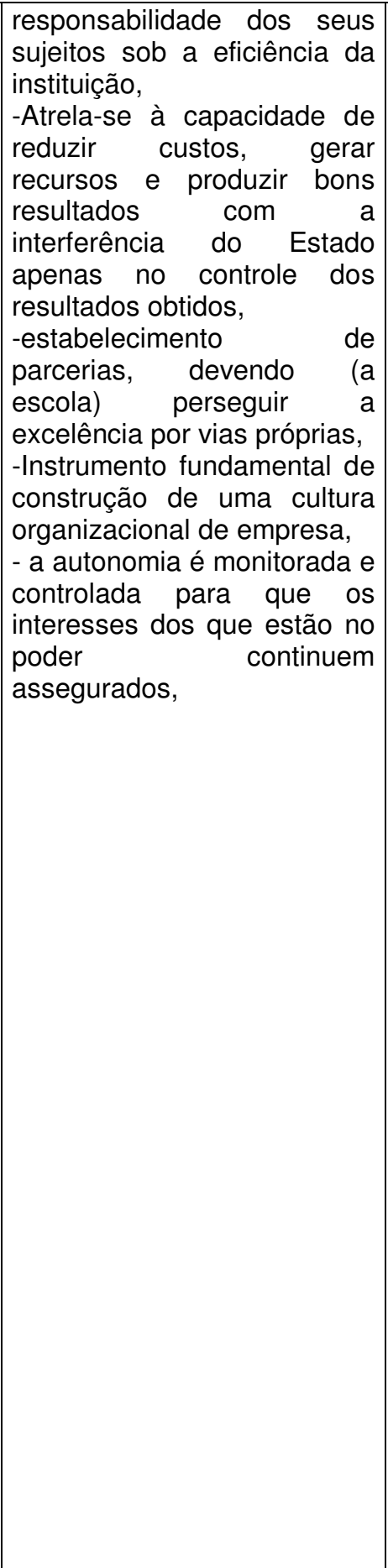 & 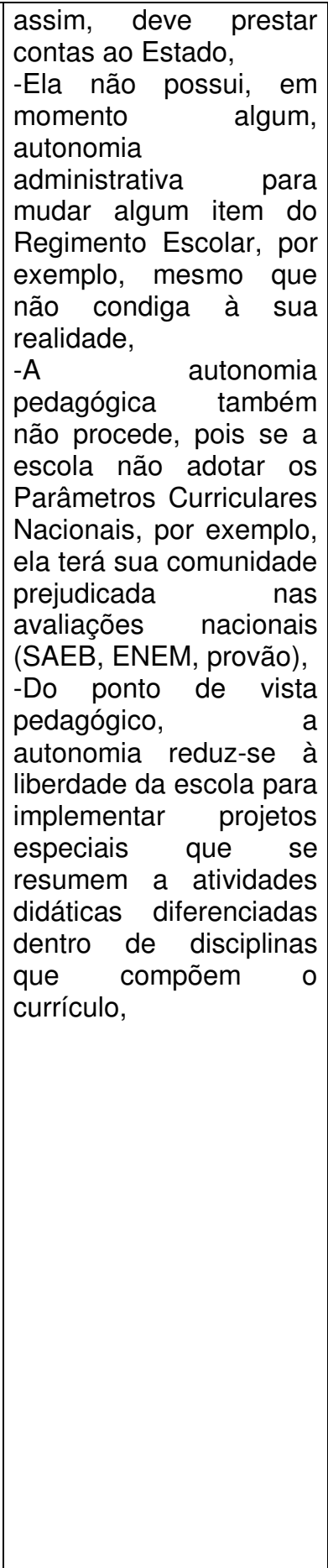 & 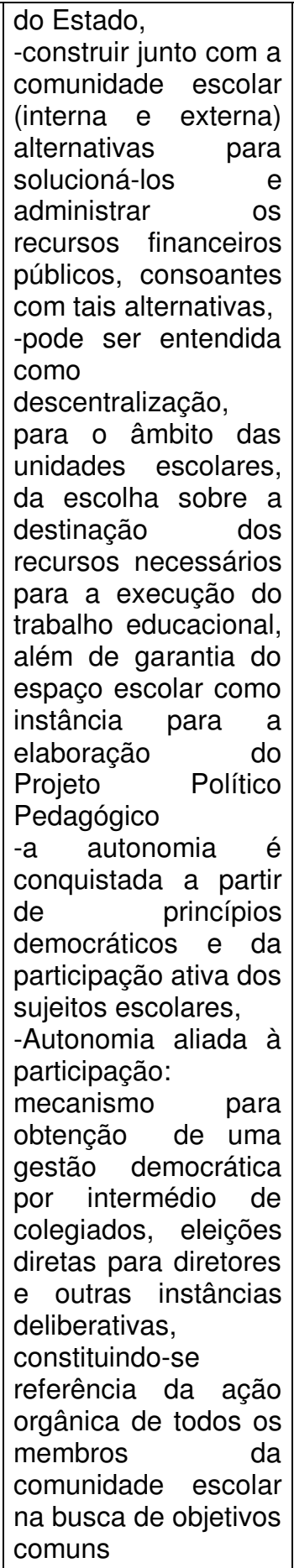 & 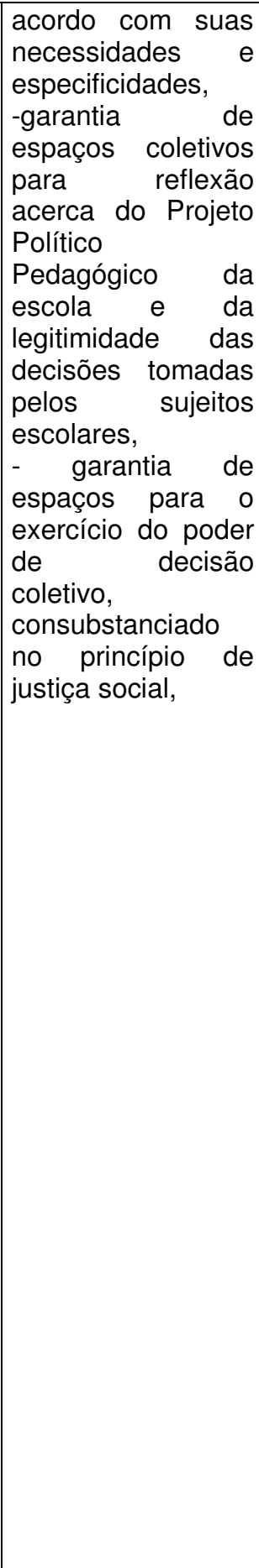 \\
\hline $\begin{array}{l}\text { DESCENTRA } \\
\text { LIZAÇÃO }\end{array}$ & $\begin{array}{|lr|}\text {-Fragmentação na base do } \\
\text { sistema escolar, dificultando } \\
\text { a articulação entre as } \\
\text { escolas, } & \\
\text {-Forma } & \text { de } \\
\text { desresponsabilização } & \text { da } \\
\end{array}$ & $\begin{array}{|ll|}\text { - as escolas, } & \text { e } \\
\text { principalmente } & \text { a } \\
\text { "dobradinha" diretor } & \text { e } \\
\text { APM, são forçados a } & \\
\text { promover eventos com } \\
\text { fins lucrativos, parceiras }\end{array}$ & $\begin{array}{l}\text {-a descentralização } \\
\text { dos diferentes órgãos } \\
\text { de governo permite } \\
\text { direcionar os gastos } \\
\text { públicos a alvos } \\
\text { específicos, }\end{array}$ & $\begin{array}{l}\text {-gestão colegiada, } \\
\text {-autonomia } \\
\text { decisória diante de } \\
\text { questões } \\
\text { administrativas, } \\
\text { pedagógicas e de }\end{array}$ \\
\hline
\end{tabular}




\begin{tabular}{|c|c|c|c|c|}
\hline & 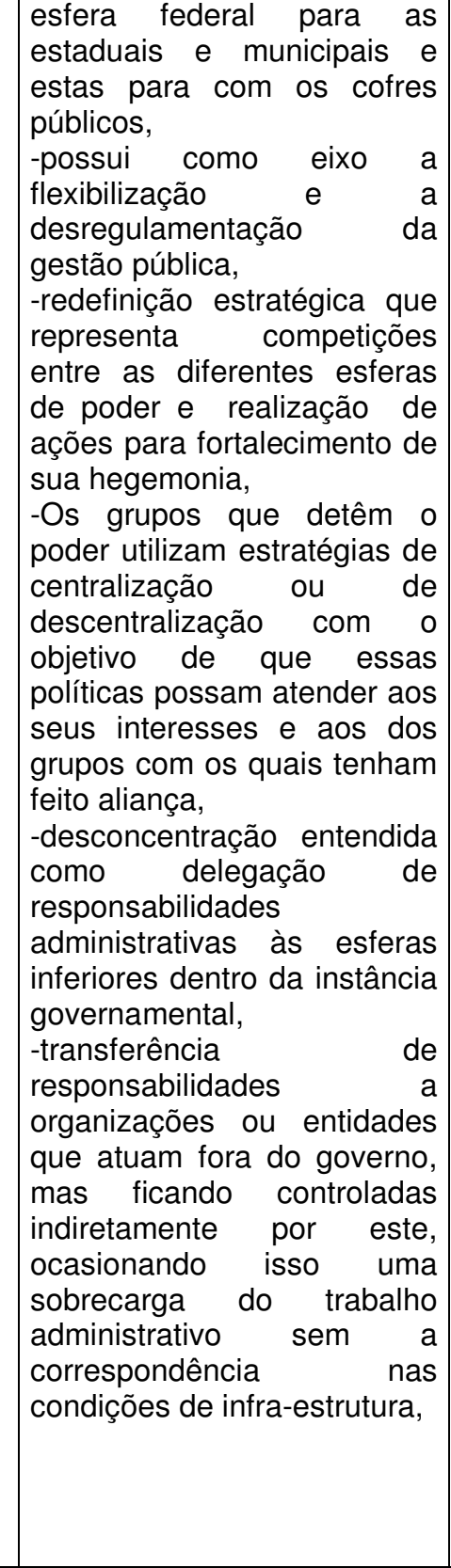 & 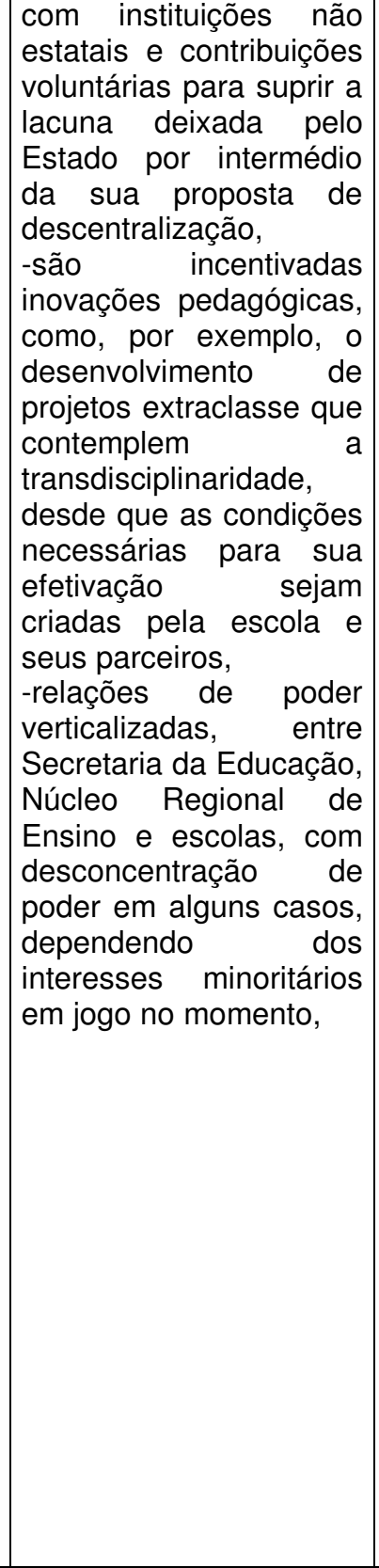 & 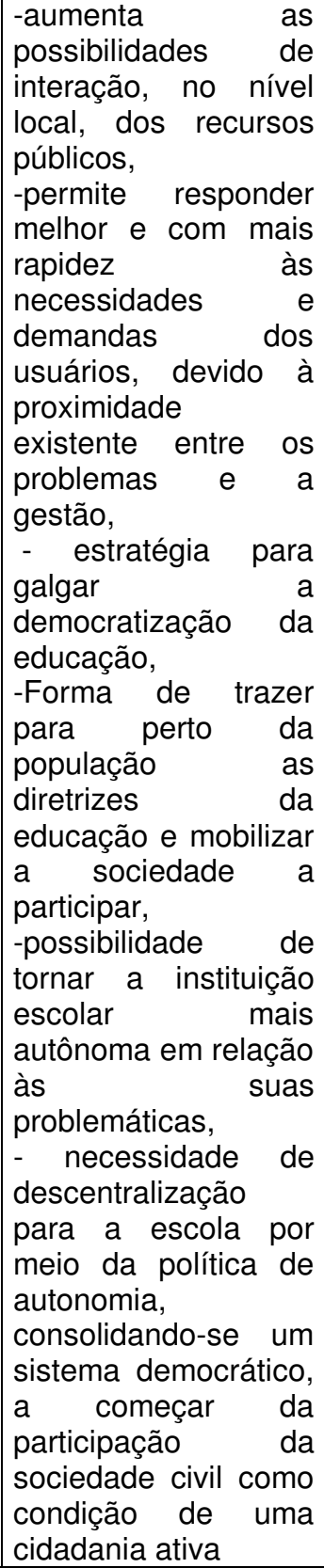 & 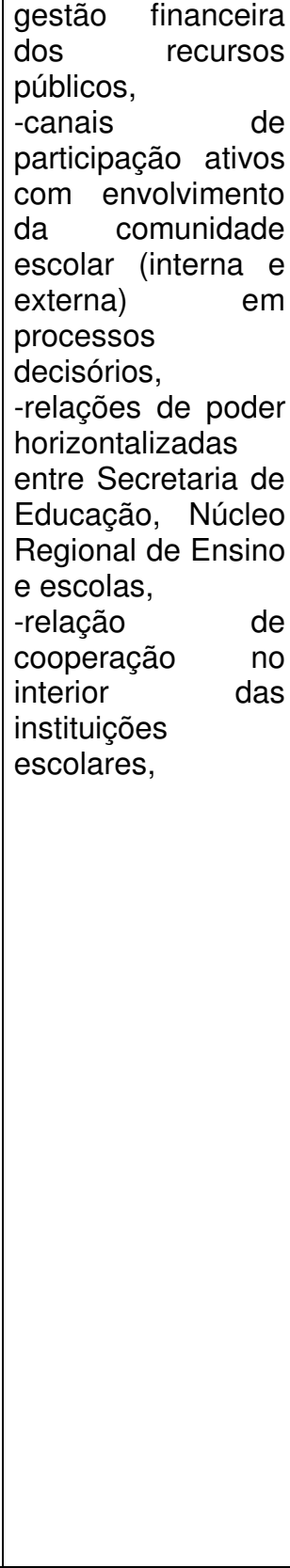 \\
\hline
\end{tabular}




\section{BREVE HISTÓRICO DA POLÍTICA EDUCACIONAL NO ESTADO DO PARANÁ}

Embora esta pesquisa objetive analisar principalmente a gestão da educação no governo de Jaime Lerner (1995-20022) e sua incidência no interior das escolas, faz-se necessário compreender alguns pressupostos da política educacional do estado do Paraná. Para tanto, far-se-á um breve histórico da política educacional do Paraná a partir do governo de José Richa (1983-86) passando pelo de Álvaro Dias (1987-1990), pelo de Roberto de Mello e Silva Requião (1991-1994) e chegando no de Jaime Lerner.

\subsection{O GOVERNO DE JOSÉ RICHA (1983-1986)}

As propostas de políticas educacionais para o governo do Paraná, elaboradas para a campanha eleitoral de 1982, defendiam uma escola na perspectiva democrática. Ao mesmo tempo, trouxeram-se propostas que previam: 1) a responsabilidade dos grupos sociais organizados para forjar seus próprios destinos; e 2) a criação de mecanismos para que a comunidade escolar (pais, mestres, estudantes e funcionários) passasse a ter participação decisiva na escolha da direção dos estabelecimentos oficiais de ensino, mediante o sistema de eleições diretas, nas escolas de todos os níveis.

Em 1983, José Richa assume o governo do Estado, tendo como Secretária da Educação a professora Gilda Poli. Nesse mesmo ano, foi divulgado o texto Políticas SEED/PR - fundamentos e explicitação (Estado do Paraná, 1984 apud Cunha, 1995), no qual se apresentavam as políticas que norteariam essa gestão. $O$ governo Richa conviveu com o fim da ditadura no país e o início do governo Sarney e uma inflação anual de 250\% (Sapelli, 2003).

A nova política educacional pretendia propiciar a retomada do ensino público gratuito, especialmente o ensino fundamental, garantindo a oferta mediante sua expansão, conservação, reparo de rede e sua melhoria qualitativa. Entretanto, observam-se contradições para sua efetivação. Explica Cunha (1995):

"A finalidade era a 'reconstrução social', isto é, a escola deixa de contribuir, pela educação, para que a maioria da população continuasse a ser alijada dos 
processos decisórios, administrativos, políticos, científicos ou tecnológicos, em nome de sua ignorância ou incompetência" (p.234).

Já nesse contexto propunha-se a participação e a descentralização como formas de adequação da política educacional à tendência que a política neoliberal vinha construindo. No que tange à participação, a Secretaria propunha aos professores que aprendessem com os pais e alunos os 'elementos da comunidade', das associações e dos sindicatos. Na mesma direção, pretendia-se promover a descentralização da própria Secretaria de Educação e a superação da postura tecnocrática. A descentralização administrativa da Secretaria Estadual de Educação (SEED) teve início mediante a transferência dos Núcleos Regionais de Ensino (NRE) que tinham sede em Curitiba para vinte microrregiões.

Nesse contexto, o governo estadual optou por uma política de expansão do ensino fundamental que priorizava a transferência de recursos para as prefeituras por intermédio da FUNDEPAR ${ }^{25}$, com a justificativa de que a compra de material e a contratação de mão-de-obra local reduziria o custo da construção de uma escola. Tal opção levou ao incentivo de uma expansão das redes municipais. Isso se fazia pela transferência de recursos para a construção de escolas e, também, para o pagamento de pessoal, através do convênio, efetivado a partir de 1984, de cooperação financeira entre o governo do Estado e 306 municípios.

Dentre essas primeiras medidas descentralizadoras, temos a distribuição do dinheiro proveniente dessa contribuição, mais a verbas da própria SEED, às escolas conforme o número de alunos, os turnos de funcionamento, a área construída e a idade do prédio. A aplicação desses recursos seria decidida pela Associação de Pais e Mestres (APMs). Tal medida é plausível desde que a verba seja suficiente para a implementação das deliberações emanadas da comunidade escolar, em especial, nesse caso, da APM.

\footnotetext{
${ }^{25}$ A FUNDEPAR (Fundação Educacional do Paraná) foi criada em 1962, com o objetivo de apoiar a Secretaria Estadual de Educação em áreas como construção, reforma, aquisição de material escolar, de limpeza e de desportos; montagem de oficinas e laboratórios, apoio financeiro e assistência técnica às prefeituras na administração e manutenção das redes municipais de ensino. Posteriormente o FUNDEPAR estendeu suas atividades para o levantamento de dados estatísticos e para a pesquisa educacional. Em 1983, a FUNDEPAR passou a coordenar o programa de alimentação escolar, material didático, saúde e bolsas de estudos, desenvolvido com recursos da Fundação de Assistência ao Educando (FAE), do Ministério da Educação.
} 
Nesse período, ainda de acordo com os estudos de Cunha (1995), duas importantes questões se articularam no quadro político-ideológico da política educacional: a modificação dos regimentos escolares e as eleições de diretores.

Com relação ao primeiro, a Resolução 325/1985 contemplava o solapamento dos elementos autoritários do regimento. Com isso, retirou-se do diretor a competência para cancelar matrícula de aluno e para indicar os professores a serem contratados, retirou-se-lhe a competência para homologar os estatutos da APM e dos demais órgãos cooperadores e extinguiu-se o 'livro de ocorrências disciplinares', entre outras supressões $^{26}$.

Com relação ao segundo, os procedimentos utilizados para a eleição ${ }^{27}$ dos diretores das escolas da rede estadual foram muito peculiares, dado que as eleições de 85 "realizaram-se praticamente na mesma época das eleições para prefeitos municipais e vereadores, o que partidarizou o processo" (Cunha, 1995).

Sapelli (2003) afirma que as medidas da política educacional que estavam sendo propostas, explicitadas no texto Políticas SEED/PR - fundamentos e explicitação, tinham caráter tanto econômico como político. O caráter econômico expressava-se na perda da capacidade do financiamento público do Estado do Paraná, nos anos $80 \mathrm{~s}^{28}$, e o caráter político, nos princípios partidários do PMDB que contemplavam a democratização em todos os níveis, a qual dar-se-ia pela participação comunitária. Tal partido anunciava um compromisso com o pagamento da dívida social e a democratização do poder local e, no âmbito educacional, segundo Santos (1998), o compromisso era com a promoção da participação da comunidade escolar, interna e externa, resultando num processo de democratização da gestão escolar, centrada nas eleições para diretores escolares. Santos (1998) afirma, ainda, que não foi sistematizada uma proposta pedagógica congruente com os preceitos democráticos anunciados.

\footnotetext{
${ }^{26}$ Apesar do caráter liberalizador de tais supressões, houve muitas críticas a essas medidas por parte das entidades de professores e dos próprios diretores de escola, que, eleitos, queriam ser ouvidos a respeito. Diante disso, a SEED, em 1986, teve a iniciativa de propor que cada escola elaborasse seu próprio regimento, reunindo professores, funcionários, pais e alunos.

${ }^{27}$ As primeiras eleições foram realizadas em 1983 com a participação de cerca de 2 milhões de pessoas em 3.500 escolas da rede estadual. Da eleição saía uma lista tríplice que era analisada pela SEED que obedecia aos critérios: currículo, plano de trabalho e parecer dos inspetores de ensino. No governo de Álvaro Dias os critérios foram mudados. Ver Cunha (1995) e Santos (1998).

${ }_{28}$ De acordo com Santos (1998), os gastos da SEED com o ensino fundamental diminuíram gradativamente nesta gestão. Em 1983 eram de 56;1\%, em 1984 eram de $58 \%$, em 1985 eram de $56 \%$ e em 1986 eram de $54 \%$ os gastos com esse nível de ensino .
} 
Em 1985, com o objetivo de discutir a democratização da escola, a SEED promoveu o "Seminário sobre a dimensão política da educação". O documento trazia as políticas setoriais emanadas do seminário, as quais explicitavam a intenção de democratizar as relações no sistema escolar. Tal anúncio ocultava, porém, a descentralização controlada do governo que estava imersa na rede político-ideológica neoliberal, a qual combinava descentralização dos mecanismos de financiamento e gestão do sistema com centralização do controle pedagógico, através do currículo, da avaliação do sistema e da formação de professores (Gentili, 1998).

Tanto no documento Políticas SEED/PR - fundamentos e explicitação (1984) quanto no resultado da discussão no seminário, percebem-se medidas que anunciavam a educação como possibilidade de ascensão social, anunciando preceitos democráticos, tais como: melhorar as condições de trabalho e promover a valorização docente, incentivar a participação popular, democratizar o poder pela participação das comunidades nas decisões da escola, entre outras medidas. Entretanto, segundo Sapelli (2003), tais medidas estavam inseridas nas reformas da educação, especificamente na reforma mais ampla promovida pelo neoliberalismo, "que era justamente utilizar-se da mesma para ampliar o mercado consumidor e gerar estabilidade política (...)" (Sapelli, 2003:37).

Percebe-se que a descentralização da educação no Estado do Paraná, desde o primeiro governo do PMDB, associou mecanismos descentralizadores, ora em perspectiva conservadora, ora em perspectiva transformadora. Entretanto, é na gestão Lerner que é possível perceber uma maior coerência tanto no discurso quanto na prática, em perspectiva conservadora neoliberal.

O governo Richa ${ }^{29}$ representou um momento de reorganização do Paraná atendendo à demanda mais ampla de reforma do Estado e reconstruindo um quadro conceitual para a educação. Entretanto, podemos afirmar que, dando continuidade à regência do partido, foi o governo de Álvaro Dias que deslanchou a operacionalização de tais propostas.

\footnotetext{
${ }^{29}$ Cunha (1995) considera que no governo em questão houve politização (partidária) do discurso pedagógico e da gestão do sistema educacional, porém sem alterações concretas no interior das unidades escolares.
} 


\subsection{O GOVERNO DE ÁLVARO FERNANDES DIAS (1987-1990)}

De acordo com os estudos de Sapelli (2003), as diretrizes do governo Álvaro Dias para a educação pautavam-se nos mesmos pressupostos do governo anterior: democratização do acesso à escola, reordenamento interno do sistema educacional e educação como fator efetivo de mudança social.

No documento "Diretrizes para a política educacional paranaense" (1987), analisado por Santos (1998), apontava-se como prioridades: correção da disparidade entre idade e série; criação do Ciclo Básico de alfabetização; definição de conteúdos básicos; melhoria das condições do trabalho docente; programa de atendimento préescolar; adequação ao ensino rural; ampliação do acesso e permanência dos alunos do ensino médio e reestruturação dos cursos desse nível de ensino; incentivo ao ensino supletivo e destinação de recursos financeiros à educação especial.

Em outro documento: "Propostas para discussão de filosofias e políticas operacionais na área da SEED/PR" (1987), estudado por Sapelli (2003) expressou-se a preocupação em dar continuidade ao projeto em andamento. Acrescentou-se, ainda, o conceito de escola competente, o mesmo que iria subsidiar a gestão de excelência do governo de Jaime Lerner (1995-2002).

\footnotetext{
"Escola competente é aquela que, em prazos e custos razoáveis é capaz de dotar os estudantes das capacidades intelectivas básicas e dos instrumentos de acesso ao saber, compatíveis com sua idade e estágio educacional" (Paraná, 1987, IN: Sapelli, 42-3:2003).
}

Percebe-se, na adoção de tal conceito, a racionalidade administrativa sustentada pela desconcentração, através das ações dos Núcleos Regionais de Ensino, das APMs e Conselhos Escolares.

A função de minimização do Estado para as questões sociais se explicitou no governo Álvaro Dias, por meio do retrocesso do poder sindical; da descentralização do sistema escolar em questões de interesses políticos; da ênfase na educação básica (seguindo os ditames dos organismos internacionais); implementação de políticas compensatórias $^{30}$.

O processo de municipalização do ensino fundamental ( $1^{a}$. a $4^{a}$. série), dessa gestão, pautou-se principalmente nas questões financeiras. Em 1987, os valores custo/aluno/ano foram quase iguais para o Estado e para as redes municipais. $O$

30 O caráter compensatório se expressa nos projetos especiais, tais como: Tempo de Criança, ProMunicípio e Os livros criam Asas. 
Estado passaria a atuar nos municípios sobrecarregados, assumindo encargos e, em outros, transferindo responsabilidades. Isso caracterizava um processo crescente de desconcentração das questões financeiras, ao mesmo tempo que se mantinha a centralização no controle do sistema escolar.

No que se refere ao processo de municipalização, as conclusões da pesquisa do IPARDES foram as seguintes (Santos, 1998): houve centralidade da dimensão financeira e administrativa; a adesão à municipalização foi marcada pela pressão exercida pelo governo estadual; os municípios, ao aderirem à municipalização, não fizeram uma avaliação de suas condições financeiras e gerenciais; houve unilateralidade do controle do processo de municipalização por parte do governo do Paraná; o processo de municipalização apresentou riscos à concepção de "escola unitária e do padrão único de qualidade"; houve atraso dos salários dos professores em vários municípios; houve diferenciação entre a posição assumida pelo NRE e pelos municípios em relação à municipalização; os recursos financeiros repassados aos municípios foram insuficientes.

Além do processo de municipalização, em 1987, iniciou-se a elaboração do Ciclo Básico de Alfabetização a partir de encontros promovidos pela superintendência da SEED. A proposta que deveria abranger princípios qualitativos e democratizantes pendia para um processo de aligeiramento da escolarização e para a alteração nos índices de evasão e reprovação com a preocupação apenas de racionalizar os custos do processo e não com a sua qualidade. Foi nesse contexto que se elaborou o Currículo Básico do Paraná (CB) que trazia uma concepção de educação históricocrítica. Entretanto, não se assegurou a participação do professorado na elaboração de tal proposta pedagógica para o ensino fundamental com o intuito de esgotar as possibilidades de construção e avaliação processual e coletiva.

Além destas políticas de descentralização que evidenciava o processo de minimização do papel do Estado com as questões sociais e a ênfase na educação básica, também merece menção o retrocesso do poder sindical ${ }^{31}$. No período em que Álvaro Dias governou havia descontentamento dos professores, e várias greves foram

\footnotetext{
${ }^{31}$ De acordo com Gentili (1998), os sindicatos são, para os neoliberais, um dos culpados pela crise educacional. Os sindicatos justamente exigiram do Estado aquilo que, na perspectiva neoliberal, gera a própria crise: mais intervenção, aumento dos recursos, critérios igualitários, expansão da escola pública, etc.
} 
deflagradas. Em 1988, houve uma greve ${ }^{32}$ que durou 47 dias. A principal causa da greve foi o não-cumprimento, firmado na gestão anterior, do piso de três salários mínimos.

\begin{abstract}
"Se por um lado ocorreu o retrocesso do poder sindical e perdas salariais, por outro houve aperfeiçoamento no processo de escolha dos diretores, 1500 cursos de capacitação no Cetepar para professores e reestruturação do curso de magistério que passou a ter quatro anos. Tais questões, aparentemente contraditórias, demonstram que as mudanças foram gradativas no modelo de gestão" (Sapelli, 2003).
\end{abstract}

Santos (1998), ao concluir sua análise da gestão de Álvaro Dias, pautando-se nos estudos de Evangelista \& Schmidt (1992), afirma que o CBA e o CB para as escolas públicas paranaenses representaram avanços importantes. Entretanto, não foram criadas as condições financeiras, administrativas e políticas, por parte da SEED, para que sua implementação fosse satisfatória para toda comunidade escolar. A autora demonstra, apresentando dados consistentes, que continuou o decréscimo orçamentário para a educação, ano a ano, mesmo com o aumento do número de matrículas, e que esse período foi marcado por uma relação conflitiva entre o governo e os trabalhadores da educação, por conta da precarização das condições de trabalho e do arrocho salarial.

A política de municipalização do ensino, que tem na Constituição Federal de 1988 a sua primeira formulação, é implementada no PR em 1990 num contexto tenso entre o governo do Estado e o professorado. Tal embate contribuiu para o decréscimo dos investimentos em educação por parte dos poderes públicos, principalmente com a realização de convênios ${ }^{33}$ de cooperação financeira. Mas é no governo seguinte que o processo de municipalização se intensifica.

\footnotetext{
${ }^{32}$ Unidos, os professores partícipes desse movimento demonstravam indignação. A resposta dada pelo governo foi de humilhações e agressões morais e físicas, pois até polícia montada "atacava" os manifestantes, entre outras atitudes autoritárias e desrespeitosas.

${ }^{33}$ "Tais convênios resultaram de uma iniciativa em que um acordo de cavalheiros (na realidade não passava de um acordo político) precedia a convênio formal, pelo qual a prefeitura assumia a responsabilidade de contratar pessoal necessário ao funcionamento das escolas estaduais de $1^{a}$. a $4^{a}$. séries e a Secretaria de Estado de Educação repassava os recursos ressarcindo o município. Tal procedimento acomodava a crescente falta de professores e de pessoal administrativo decorrente da falta de concursos públicos e respondia à expectativa dos municípios de contarem com maiores recursos em seus parcos orçamentos" (Santos, 1998:172).
} 


\subsection{O GOVERNO DE ROBERTO DE MELLO E SILVA REQUIÃO (1991-1994)}

As principais ações do governo Requião para o setor educacional respondiam, no início dos anos 90s, às novas diretrizes do Banco Mundial ${ }^{34}$. Entre as principais ações podemos ressaltar o acirramento do processo de municipalização, a valorização de experiências inovadoras, a construção dos projetos político-pedagógicos das escolas, o plano de capacitação docente, os altos investimentos na administração e as negociações com o BIRD e o BID.

Tais ações destacam-se, pois, como nos elucida Silva (1998), é precisamente nesse governo que se detecta um impulso no deslocamento da proposta de cunho democrático, mesmo que sob influência capitalista, para propostas ligadas ao referencial de modernização para a competitividade, que, nas considerações de Gentili (1998), significa "transferir a educação da esfera da política para a esfera do mercado, negando sua condição de direito social e transformando-a em uma possibilidade de consumo individual" (p.19 grifos meus).

Nessa perspectiva, o governo Requião, tendo a autonomia como eixo, e como desdobramentos a descentralização e a participação, buscou estimular o crescimento da responsabilidade da comunidade e da escola, diante de suas necessidades materiais e gerenciais. Verificamos, com isso, o empenho em ajustar o sistema escolar paranaense às novas diretrizes do Banco Mundial ${ }^{35}$ que se inclinam para a redefinição dos preceitos "descentralização", 'gestão democrática “,” autogestão “," autonomia “,” participação “, perceptíveis, não com a mesma ênfase vista no governo de Jaime Lerner, na política educacional e expressa, principalmente, no documento Construindo uma escola cidadã".

Maria Dativa de Salles Gonçalves, analisando esse período e ressaltando o pressuposto de autonomia, destaca de tal documento a seguinte questão:

“... parte-se da hipótese de que o desempenho escolar depende prioritariamente

\footnotetext{
${ }^{34}$ De acordo com Torres (1996), as reformas educacionais propostas pelo BM para os anos 90s, inclui: a prioridade para a educação básica, a melhoria da qualidade (e da eficiência), a prioridade sobre os aspectos financeiros e administrativos da reforma educativa, a descentralização e instituições escolares autônomas e responsáveis por seus resultados, a busca por uma participação dos pais e da comunidade nos assuntos escolares, o impulso do setor privado e das Organizações Não-Governamentais (ONGs), a mobilização e alocações adicionais para a educação, um enfoque setorial e a definição de políticas e prioridades baseadas na análise econômica (Torres, 1996, p. 129).

35 As negociações entre o governo paranaense e o Banco Mundial desembocaram no "Projeto de Qualidade no Ensino Básico do Paraná" (1994), o qual só foi implementado no governo de Jaime Lerner.
} 
política educacional: consolidação da gestão democrática, estabelecimento de comunicação direta com as escolas e comunidade, incentivo às escolas para a elaboração autônoma dos projetos pedagógicos e criação de sistemas de avaliação permanente" (Gonçalves, 1994:38).

Ou seja, esse documento indica a disposição do governo em transferir para as escolas mais responsabilidades administrativas e de financiamento, incentivando a participação da comunidade na definição dos objetivos das escolas, bem como na avaliação do seu desempenho. Segundo a autora, a autonomia implementada nesse governo constitui-se uma estratégia de modernização conservadora e não de democratização do ensino.

Como mecanismo de modernização da escola, essa gestão começa a potencializar propostas de convênios, estimulando as escolas a buscarem melhorar sua infra-estrutura a partir de parcerias.

Sapelli afirma que no documento em questão a SEED/PR explicitava os quatro princípios que norteariam a nova proposta educacional: consolidação da gestão democrática; estabelecimento de comunicação direta da secretaria com as escolas e dessas com a comunidade; incentivo às escolas para que elaborassem e executassem autonomamente seus projetos pedagógicos e criação de um sistema de avaliação permanente do desempenho escolar.

Tais princípios sustentam-se da ressignificação do modelo de gestão, em perspectiva neoliberal, num contexto que, no seu âmago, buscava a minimização do papel do Estado relativamente às questões sociais, incentivando a proposta e dando Ihe credibilidade, através de, além de outros procedimentos meritocráticos, premiações. Nesse contexto, sugeriu-se uma premiação para as escolas que expressassem a capacidade de gestão compartilhada ${ }^{36}$. No governo Lerner acontece o aprimoramento dessas premiações, inclusive com viagens ao exterior, encontrando-se nessa prática a legitimação e o consenso (falsificado, segundo Gentili, 1998) para a manutenção das estratégias neoliberais.

A questão da premiação chama a atenção, pois, como adotar a competição, para posterior premiação, dentro de uma proposta de gestão democrática? Ou seja, a competição que antecede a premiação é uma prática individualista que ressalta,

\footnotetext{
${ }^{36}$ Tal ressignificação, em perspectiva neoliberal, desemboca numa proposta de gestão compartilhada que iremos discutir no decorrer do texto.
} 
indiretamente, os princípios mercantis. Ela é a materialização e/ou a valoração da fetichização ${ }^{37}$ política da gestão escolar.

Como se pode notar, houve um esforço do governo Requião em responder às diretrizes do BM. Em algumas questões tal objetivo foi alcançado, em outras, porém, não houve articulação suficiente para sua concretização. No entanto, tal articulação viabilizou a execução de tais questões no governo Lerner, que fez novos realinhamentos e, nessa lógica de governo, obteve maior sucesso.

Nos encaminhamentos executados pela SEED/PR, é possível perceber a insuficiência de tais objetivos para a realidade e necessidades educacionais paranaenses, quando analisa-se:

I. O processo de municipalização das escolas (séries iniciais tanto no regular como no supletivo e a educação especial), que se reduz a desconcentração/transferência de responsabilidades;

II. O processo de eleição para diretores, ora democrático, ora controlado;

III. As tendências pedagógicas que deram base às propostas de cada governo: ora histórico-crítica, ora neotecnicista ${ }^{38}$;

IV. A ênfase no ensino fundamental e na ampliação do ensino médio sempre com a preocupação maior de "padronização do comportamento social" e "instrução do consumidor" tão necessária para a consolidação do modelo neoliberal;

V. Os projetos de combate à evasão e a repetência, ou seja, de correção de fluxo escolar (como CBA, supletivo e outros), que mais correspondiam a deteriorização da qualidade (que restava) do ensino, por forjarem, em detrimento desta qualidade, estatísticas que, de certa maneira, condicionaram os empréstimos do BM para o Paraná.

Nesse governo a administração dos recursos humanos foi marcada por críticas ao desempenho dos servidores públicos, especialmente aos professores, medidas

\footnotetext{
${ }^{37}$ Sobre a ênfase na gestão escolar nas estratégias neoliberais e a hipótese de se caracterizar em fetiche político no Estado do Paraná ver no item 3.2 "A apropriação do paradigma da "qualidade total" pela gestão escolar".

${ }^{38}$ De acordo com Sapelli (2003), a SEED/PR propôs, do ponto de vista pedagógico, uma teoria que se desarticulava do conjunto de práticas proposto por ela mesma, explicitado em documento que primava pelo "planejamento como instrumento estratégico", pelo redimensionamento dos espaços-tempo das escolas", pela operacionalização até a avaliação". Essas propostas, segundo a autora, fazem parte de princípios neotecnicistas por enfatizarem o planejamento operacional (p.60).
} 
populistas e paliativas quanto à situação de servidores e professores, correção dos salários pelos índices de inflação mensal e negociação com o sindicato mediante pressão e recursos legais.

Contudo, percebe-se nos três governos do PMDB no Paraná, recémapresentados, um movimento crescente de desregulamentação/regulamentação, centralização/descentralização do Estado que foi gradativamente reduzindo sua intervenção no financiamento da educação ${ }^{39}$, porém não diminuindo o controle sobre o sistema escolar em nenhum momento. As medidas e negociações iniciadas nos governos pmdebistas, principalmente sob o comando de Roberto Requião, irão subsidiar as políticas implementadas no governo Lerner, dado seu caráter "modernizador"

\footnotetext{
${ }^{39}$ Sobre a gradativa diminuição dos investimentos em educação no Paraná, ver Santos (1998).

${ }^{40}$ Santos (1998) argumenta que o terceiro governo do PMDB, com Roberto Requião (1991-94), adquire um significado de modernidade, dadas as ressignificações do partido para a década de 90 , sob o viés do enfoque setorial em educação. A intenção de "uma educação para a modernidade" está contemplada no documento "Plano Setorial de Educação: uma educação para a modernidade" (s/d) (Santos, 1998:208)
} 


\subsection{JAIME LERNER (1995-2002): A ÊNFASE NA "GESTÃO COMPARTILHADA"}

Jaime Lerner elegeu-se governador do Paraná pelo PDT (Partido Democrático Trabalhista) e, logo depois de empossado, filiou-se ao PFL (Partido da Frente Liberal). Sua primeira gestão foi de 1995 a 1998. Em 1999 reelegeu-se, ficando no governo até 2002. Pode-se dizer que este foi o governo em que houve um grande aumento nas relações com os organismos internacionais. Os principais projetos financiados por organismos internacionais são o $\mathrm{PQE}^{41}$ e o PROEM. As principais ações do governo Lerner serão analisadas pelos documentos gerados em seu governo.

A proposta de gestão compartilhada elaborada pela SEED-PR, a partir de 1995, possui vínculos com as propostas muito difundidas nos anos 90s, por Cosete Ramos, pela Fundação Cristiano Ottoni de Minas Gerais, pelo Instituto Brasileiro de Produtividade e Qualidade-Seção Paraná, entre outros.

A composição passa a associar as expressões "Escola de Excelência", "Flexibilização do Sistema" e "Gestão Compartilhada", que se constituíram e se constituem slogans educacionais, utilizados na obtenção do consenso a tal programa. Contudo, nos textos que tentam explicar essas novas formas de organizar o sistema de ensino, retomam-se os conceitos de participação, autonomia e descentralização, num esforço de redefinir o que se entende por democracia ou gestão democrática. É o processo de apropriação do conceito histórico.

A concepção de gestão compartilhada tem sido muito difundida em cursos para gestores de empresas privadas, em que se pretende que a administração conte cada vez mais com a adesão do empregado aos propósitos da empresa. A Gestão Compartilhada inspira-se na denominada Gestão Participativa - GP, expediente de administração de empresas em que se criam situações ou espaços de intervenção dos trabalhadores nos procedimentos administrativos e comerciais, porém, raramente na condução geral da empresa ou da instituição. Essa proposta de gestão pode contribuir para a criação de nova cultura organizacional, capaz de moldar novas formas de subjetividade nas relações interior e exterior ao sistema de ensino.

\footnotetext{
${ }^{41}$ O Projeto Qualidade do Ensino (PQE), iniciado em 1994, era integrado por um total de 16 programas e 41 subprojetos, e contemplava os componentes: 1) materiais pedagógicos; 2) capacitação de recursos humanos; 3) rede física; 4) desenvolvimento instituicional; 5) estudo, pesquisa e avaliação.
} 
"A organização da escola pode contribuir para a formação de perfis de personalidades (alunos, professores, equipe de ensino, técnicos administrativos, diretores, etc) adequados à lógica da excelência, da competição e da legitimação da igualdade de oportunidades" (Silva, 1998:188).

Destacam-se até então duas importantes estratégias utilizadas no governo de Jaime Lerner: a divulgação e marketing de slogans educacionais e o processo de formação (e inculcação) para os trabalhadores em educação, principalmente para os gestores. Tais estratégias, associadas, são utilizadas na obtenção do consenso da comunidade escolar, interna e externa, em torno da Gestão Compartilhada. Tal intenção, não explicitada, pode ser desvelada a partir da importância atribuída ao componente do PROEM (1996), por exemplo, "Fortalecimento da Gestão do Sistema Educacional", que contempla projetos de mobilização social e marketing, de sistema de informações gerenciais e de gerência e execução.

Nesse governo, o "Programa Expansão, Melhoria e Inovação no Ensino Médio no Paraná" (PROEM) ${ }^{42}$, projeto financiado pelo BID, fez parte do Plano de Ação da Educação e visava três objetivos: a permanência e sucesso do aluno na escola, a capacitação dos docentes e a participação das comunidades na vida da escola, de forma mais intensa.

O subprograma denominado "Fortalecimento da Gestão do Sistema Educacional' demonstra a mudança na significação da gestão da educação, com o objetivo de torná-la ágil e eficiente sob o ponto de vista mercadológico, pretendendo ser capaz de alcançar bons resultados com recursos escassos (Viriato et. Al. 2001:188, 189). Este subprograma foi considerado a mola propulsora para a "modernização" da política educacional do Paraná. Para tanto, era necessário "capacitar" os profissionais da comunidade escolar, chamar a "participação" da comunidade e garantir o acesso e permanência dos alunos nas escolas. Como contribuir para a minimização do Estado ${ }^{43}$, já que este se mostra ineficiente? Esse subprograma tinha como objetivo

"Assegurar a sustentabilidade da melhoria na qualidade da Educação geral e modernização da Educação Técnica Profissional, por meio de apoio à

\footnotetext{
${ }^{42}$ O PROEM foi financiado pelo BID, num valor total de US\$ 222 milhões; teve início em 1998 com término em 2002 (Souza, 2001). Os recursos foram distribuídos entre os subprogramas: Melhoria da Qualidade do Ensino Médio, Modernização da Educação Técnica Profissional e Fortalecimento da Gestão do Sistema Educacional. (Paraná, 1996)

${ }^{43}$ Gentili (1998) nos elucida que, na ótica neoliberal, estamos enfrentando uma profunda crise de gerenciamento das políticas educacionais e, por conseqüência disto, temos uma profunda crise de qualidade. "Na ótica neoliberal, essa crise expressa a incapacidade estrutural do Estado para administrar as políticas sociais. Esse fato, sendo um atributo geral do assistencialismo estatal, expressa-se com uma peculiaridade própria no campo educacional: a crise de produtividade da escola não sintetiza outra coisa senão a crise do centralismo e da burocratização próprias do Estado interventor" (p.17).
} 
modernização e flexibilidade da SEED no melhoramento de sua capacidade de planejar e avaliar políticas e programas de educação" (PARANÁ, 1996:55).

Com tal ação, o governo deu um impulso maior à gestão compartilhada que se caracterizava principalmente pela necessidade de controlar as ações de quem toma as decisões finais na escola, ou seja, a APM, o Conselho Escolar e os diretores.

\begin{tabular}{l} 
"Adicionalmente o subprograma prevê ações destinadas ao fortalecimento dos \\
níveis locais de gestão e de estímulo à participação da comunidade no \\
\hline gerenciamento do processo educativo. Essas ações incluem aquelas voltadas \\
especificamente à promoção da autonomia das escolas na perspectiva de um \\
sistema no qual as decisões sejam mais descentralizadas e compartilhadas. \\
Ademais, pretende-se buscar junto à comunidade o suporte político e social e \\
estabelecer parcerias que permitam viabilizar mecanismos de sustentação \\
$\underline{\text { econômica das ações implementadas" (Paraná, 1996:55, grifos meus). }}$
\end{tabular}

Tal documento representa os mecanismos neoliberais dos anos 90s. O fortalecimento da gestão, o estímulo à participação, a promoção de "autonomia" e decisões "descentralizadas" e compartilhadas são estratégias salientadas no PROEM que merecem desconfiança, pois não esclarecem como se pretende operacionalizar tais objetivos. É na prática que foi possível perceber que todos esses objetivos específicos convergem para um objetivo maior de minimização do papel do Estado no provimento das áreas sócias, em especial em educação.

Vários procedimentos descentralizadores foram tomados nesse período dentre os quais a criação de empresas mistas (estatal e não-estatal) como PARANAEDUCAÇÃO, agência que passa a administrar os recursos humanos, inclusive as verbas públicas. Com isso, ocorre a descentralização da contratação dos professores, que passam a ser contratados pelas escolas, sob a gerência do PARANAEDUCAÇÃO.

Houve também, com a interferência de tal agência, a criação de outro quadro de carreira, que extingue vários direitos e o concurso público como forma primordial de contratação. Em conseqüência desta precarização das condições de trabalho e da proletarização do magistério, ocorre o isolamento do sindicato, com pouca negociação, inclusive com cortes no repasse das mensalidades mediante folha de pagamento.

No projeto financiado pelo BIRD, o $\mathrm{PQE}^{44}$ contém 0 "Componente: Desenvolvimento Institucional" através do qual, tanto quanto do PROEM, podemos

${ }^{44}$ O PQE (Programa Qualidade no Ensino Público do Paraná) era um programa destinado ao ensino fundamental. Os investimentos, de US\$ 196 milhões foram destinados a cinco componentes: material pedagógico, treinamento de professores, melhoria na rede física e aumento do acesso, desenvolvimento institucional e estudos e avaliação (Souza, 2001). Teve início em 1995 e foi prorrogado até 2001. 
confirmar a ênfase na gestão como mecanismo fundamental de reconfiguração do papel do Estado na educação. A justificativa é que as escolas com problemas seriam aquelas mal-gerenciadas. Para isso, houve ainda um assessoramento aos diretores para que superassem as dificuldades e contribuíssem para a efetivação dos programas. A função do diretor ganhou um destaque especial e de importância significativa para a consolidação dos programas. Isto confirma a hipótese de fetichização da gestão escolar, atribuindo a ela o papel de fio condutor no processo de redefinição do papel do Estado em direção aos preceitos mercadológicos.

Este assessoramento, podendo ser entendido como "lavagem cerebral" ou, ainda, estratégia de cooptação, está contemplado no "Componente: "Treinamento de professores" que foi desenvolvido pela SEED por intermédio da Universidade do Professor (estabelecida em 1995) e a maioria dos eventos ocorreram no Centro de Capacitação da Universidade do Professor em Faxinal do Céu/PR. As atividades de capacitação eram organizadas sob três enfoques: pedagógico, gerencial e de mobilização e comunicação. Em 2000 foram realizados 13 seminários, contratados à empresa Amaná Key que buscou preparar os gestores escolares para

“... tornarem-se capazes de se renovarem continuamente, utilizando-se de novos conhecimentos em estratégias, produtos, processo de implementação de projetos, relacionamento humano e relacionamento com a comunidade, com o propósito de se possibilitar a gestão voltada para resultados efetivos, visando alavancar o processo de autonomia das escolas" (Paraná, 2001:42).

São "treinamentos" do governo para convencer os diretores e representantes de APMs (que também participaram dos primeiros eventos) da eficácia da transferência do modelo empresarial de administração para as escolas. Além disso, receberam vários cadernos de gestão, revistas como: Gestão em Rede, O Jornal da APMs e o Jornal Direção, para orientá-los em suas ações.

Nesse processo, o Estado passa a considerar outros requisitos que formalizam a situação. Entre eles: democratização do acesso; competência na produção e difusão dos resultados dos produtos; democratização das relações de poder nas instituições; controle de recursos, entre outros. Com isso, percebe-se, mais uma vez, que a reforma do Estado propõe a substituição da administração patrimonial e burocrática pela administração gerencial.

Para Bueno, quando a administração educacional recorre a símbolos e recursos de apoio que ocultam sua verdadeira natureza não pretende, via de regra, democratizar 
a educação. Pretende gerir de forma controlada, adquirindo certo consenso, legitimando a exclusão.

Ileizi Silva (2001) interpreta o processo de mudança, no Paraná, a começar pelo tratamento dado à meta de igualdade social sugerindo que talvez algumas inflexões nesta meta possam ter desencadeado um processo de contra-reforma e não de reforma. Exemplifica como contraditório o fato de que a meta proposta era a de "busca da escola cidadã" com ênfase na "igualdade comunitária", no entanto, diz que o ideal perseguido é a escola de excelência ou a chamada "eqüidade", ou seja, a "igualdade de oportunidades". Silva (2001) ainda questiona: "Buscar a escola cidadã tem o mesmo significado que buscar a escola de excelência?" E nos auxilia a buscar a resposta conceitualizando ambas: refere-se à gestão compartilhada como originária do modelo de gestão empresarial que tem como meta a excelência dos serviços. Além disso, encontra-se comprometida com a fragmentação do sistema público de ensino, no qual as escolas deverão auto-sustentar-se. Por outro lado, conceitua a gestão democrática como uma proposta comprometida com a consolidação de um sistema público de ensino, visando um comprometimento também dos trabalhadores envolvidos diretamente com a educação.

Até 1995, os documentos afirmavam que a gestão da escola deveria ser uma "gestão democrática", passando, a partir daí, a defender a expressão "gestão compartilhada". Nesse mesmo sentido, observa-se a mudança da ênfase do tipo de escola que se pretendia construir no Paraná. Até 1995, abusava-se da idéia de escola cidadã ${ }^{45}$; a partir daí, enfatiza-se a idéia de escola de excelência ${ }^{46}$. A primeira idéia pressupõe atividades coletivas e a segunda, atividades competitivas.

A relação entre marketing, divulgação e propaganda, com os slogans educacionais e a fetichização da educação vai configurando e imergindo-se cada vez mais na lógica mercadológica na educação, documentada no PROEM e no PQE e viabilizada a partir dos eventos promovidos em Faxinal do Céu e na disseminação de materiais de instrução para as escolas, principalmente no que tange à gestão escolar.

\footnotetext{
45 A escola cidadã, proposta emanada da gestão de Roberto Requião (91-94), implica na gestão democrática, baseada no envolvimento da comunidade, na autonomia e avaliação, sendo esses três pontos básicos que configuram a escola cidadã.

${ }^{46}$ A escola de excelência se dá através da gestão compartilhada e da flexibilização do sistema, sendo essa articulação a produtora da escola de excelência. Essa política educacional teve como precursor Jaime Lerner (1995-2002).
} 
"... os seminários (em Faxinal do Céu) objetivam criar um consenso de que as políticas implementadas são adequadas e as mais avançadas no sentido da democratização da escola pública, como se o moderno fosse inexorável e indiscutivelmente positivo. Usando um termo propriamente gramsciniano, poderíamos também nominar esse processo como uma busca do 'consenso espontâneo', a busca do consenso favorável a tais políticas, situando-se o professor numa posição passiva de aceitação das políticas em implementação. Um consentimento que 'livremente' dos professores, para concordar com o rumo dado à educação no Paraná" (Souza, 2001:88)

Nesse sentido, salienta-se a necessidade de redução dos níveis hierárquicos, de descentralização e de autogerenciamento de departamentos/setores, delegam-se tarefas e compartilham-se responsabilidades, circulam informações (os objetivos e os planos da empresa devem ser amplamente conhecidos e divulgados) e discursam transparência nas decisões. Tais recomendações configuram a denominada Gestão Participativa (GP) que apregoa a tomada de decisão por consenso que deve traduzir-se na garantia do comprometimento do grupo com os objetivos da empresa, de tal forma que eles se transformem em preocupação central na vida do trabalhador.

Tomaz Tadeu da Silva (1994) afirma ser a construção da política como manipulação do sentimento; transformação do espaço de discussão política em estratégias de convencimento publicitário; celebração da suposta eficiência e produtividade da iniciativa privada em oposição à ineficiência e ao desperdício dos serviços públicos; e redefinição de cidadania pela qual o agente político se transforma em agente econômico e o cidadão em consumidor. São exatamente tais estratégias políticas que o governo Lerner operacionalizou com sucesso no Paraná.

É nesse projeto que se insere a redefinição da educação em termos de mercado, atribuindo-se à gestão, com caráter fetichizado, a responsabilidade de liderança, ou de fio condutor (Frigoto,1994) no processo de redefinição do papel do Estado nacional ${ }^{47}$.

Com a implementação da proposta de gestão compartilhada no Paraná, a participação ${ }^{48}$ vem sendo utilizada como instrumento útil ao processo de redefinição do papel do Estado e, ainda, monitorada e submetida aos interesses privatistas do Estado.

\footnotetext{
${ }^{47}$ As mudanças nas propostas de gestão presentes nas políticas educacionais implementadas no governo do estado do Paraná estão inseridas num processo amplo de alterações nas políticas públicas, cujo fulcro central são as concepções e o papel do Estado e da sociedade na definição, implementação e avaliação das políticas públicas.

${ }_{48}$ Para Lima (2000), a descentralização e participação surgem associadas a técnicas de gestão eficazes com vista à racionalização e otimização dos sistemas educativos.
} 
Isso pode ser constatado desde a primeira gestão do PMDB no governo do Estado, mas intensificou-se no governo de Jaime Lerner.

No Paraná é possível perceber a contradição, pois o ideal de participação, interrelacionado aos ideais de descentralização e autonomia, aparece nos projetos PQE e PROEM como conceitos subsidiários, mas não envolveu as escolas e as comunidades atendidas na elaboração dos programas, o que demonstra o quanto o governo está interessado nas necessidades e interesses das camadas populares, denunciando, assim, uma concepção de participação reducionista, institucionalizada e controlada.

Os documentos mencionados anteriormente foram operacionalizados no governo de Jaime Lerner (1995-2002), mas começaram a serem negociados no governo de Roberto Requião (1991-1994). Neste último, a política educacional do Paraná teve assessoria do Instituto Paulo Freire, apresentando, principalmente no documento "Construindo a Escola Cidadã", uma concepção de participação mais comprometida com os setores populares ${ }^{49}$. Isto pode ser percebido em um dos textos que serviram de base para a construção de tal documento:

"Para que a escola possa construir o seu projeto-político-pedagógico, a participação de todos e, em especial, de seus docentes, é condição essencial. Isso contribui para a democratização das relações de poder no âmbito escolar e, por conseguinte, pode levar os usuários á intervenção no próprio sistema de ensino" (Paraná, 1992:10).

No governo de Jaime Lerner, a participação ganha referências da GQT, sendo, portanto, completamente díspares das referências da concepção de participação da "escola cidadã" e demonstrando, através do PQE, no eixo que prioriza a participação da comunidade, seus princípios neoliberais norteadores:

- Organização de instrumentos institucionalizados, realização de parcerias e criação de entidades jurídicas sem fins lucrativos para a integração de segmentos da comunidade junto ao sistema educacional, visando sua efetividade e satisfação da população;

- Efetivação de ações conjuntas com os setores produtivos da sociedade para desenvolvimento do ensino médio de natureza profissionalizante;

- Revisão do processo de integração entre estado e município, possibilitando maior suporte ao transporte escolar e à capacitação dos professores, além de planejamento conjunto de rede física, em municípios de maior porte;

- Mobilização da comunidade para monitoramento das ações referentes à execução dos Planos Educacionais, de âmbito nacional, estadual, regional e local;

\footnotetext{
${ }^{49}$ Perspectiva de participação política que reflete os interesses do poder local. Forma de trazer para perto da população as diretrizes da educação e de mobilizar a sociedade a participar.
} 
- Divulgação periódica de resultados do desempenho do sistema educacional, mediante órgãos de imprensa escrita, falada e televisiva (PQE, Paraná, 1995: $\mathrm{s} / \mathrm{p})$.

É possível perceber a relação entre a essência mercadológica e competitiva com seu pretendido impacto na gestão escolar, utilizando-se a participação como estratégia para obtenção do consenso e de modelamento do comportamento dos trabalhadores em educação acerca dos ditames da gestão compartilhada.

No PROEM, o conceito de participação se apresenta de maneira genérica, mencionando que objetiva "obter a participação crescente e ativa da população, e especialmente da comunidade local” (Paraná, 1996:57).

Pode-se assinalar que os conceitos de participação nas duas gestões convergem, quanto à busca pela intervenção dos usuários, para o sistema de ensino. $\mathrm{A}$ grande diferença é a forma de participação ou a ênfase que se dá à participação em determinada questão escolar. Ou seja, na "escola cidadã" proposta no governo de Roberto Requião, deveria haver a participação dos âmbitos administrativos, pedagógicos e financeiros nos processos decisórios, mas a ênfase recai no aspecto pedagógico ${ }^{50}$. Já no governo de Jaime Lerner, a "escola de excelência" enfatiza a "participação" no aspecto financeiro, de maneira velada e sutil.

No governo de Roberto Requião a municipalização, como forma de descentralização, ganhou especial atenção, como se pode perceber no documento oficial de tal período:

"Co-manutenção das escolas em regime de colaboração com municípios e a comunidade incluindo empresas públicas e privadas. Nesse campo, destacamos os Convênios com associações, empresas e faculdades. Por exemplo, para a colaboração de estagiários dos cursos profissionalizantes. O município é a base do exercício de cidadania; é a primeira representação concreta do Estado, unidade de programação e de ação conjunta das escolas situadas em seu território (Escola, Município, Núcleos Regionais de Educação, Secretaria de Estado)" (Paraná: Construindo a escola cidadã, 1992:18).

Entretanto, pode-se perceber que os processos descentralizadores não chegam a transferir poder para as escolas ou promover a articulação das bases locais. Os dados empíricos possivelmente não demonstram a existência de alterações substantivas nas estruturas administrativas reforçadoras da capacidade de ação das escolas.

\footnotetext{
${ }^{50}$ Foi nesse contexto que houve o incentivo para a elaboração do projeto político-pedagógico das escolas, sendo considerado como construção coletiva. A SEED propôs que "os estabelecimentos de ensino (...) terão a incumbência, entre outras, de elaborar e executar sua proposta pedagógica (...), articular-se com a família e a comunidade, criando processos de integração da sociedade com a escola (...), construir conselhos escolares com representação da comunidade (...), e prestar contas e divulgar informações referentes ao uso de recursos e à qualidade dos serviços prestados" (Paraná, 1992:11). Entretanto, contraditoriamente, houve pressão quanto aos prazos e inflexibilidade quanto ao modelo de projeto que a secretaria propunha, não garantindo que o projeto fosse, de fato, a cara da escola, e que fosse uma atividade, de fato, coletiva.
} 
Pelo contrário, "estudos sobre as experiências de descentralização no setor da educação em países como o Peru, Chile e México (Street, 1986:26-40), nas décadas de 60, 70 e 80, mostram como as iniciativas dos governos militares destacaram-se nesse período pelas ações para desorganizar as resistências de grupos constituídos pelos professores, para ampliar as estruturas administrativas e implementar uma reforma educativa que propalava a participação, no entanto, submetia os professores a um processo de neutralização política e submissão a um programa de ampliação do número de alunos em sala de aula, restrição de recursos para a educação e manutenção de baixos níveis salariais. Essas situações, no entanto, foram enfrentadas pelos professores mediante resistência ativa e passiva, significando, portanto, o caráter polêmico dessas políticas implementadas sob a égide da democratização do país" (ROSAR, 1997:112, in: OLIVEIRA, 1997).

A idéia disseminada de parceria entre a escola pública e setores da comunidade como forma de descentralização e autonomia, as quais ao se restringirem em ações de captação de recursos para provimento das necessidades básicas da instituição escolar podem aprofundar o fosso que separa escolas de um mesmo sistema, criando condições perversas e eximindo o Estado do financiamento da educação.

Nos objetivos do PQE vê-se reiterada a importância da descentralização para o Banco e para o governo do Paraná, lembrando-se que o Estado firmou um compromisso de garantir

\begin{abstract}
“... a continuidade de várias iniciativas políticas que formam o contexto para o programa, a saber: (a) o Ciclo Básico de Alfabetização (CBA); (b) o programa de parceria com os municípios; (c) a participação comunitária na escolha dos diretores das escolas; (d) incentivar maior autonomia na tomada de decisões ao nível de escola, através do repasse de recursos não salariais às escolas por meio de um fundo rotativo". (Projeto de qualidade de ensino básico do Paraná, 1994:22).
\end{abstract}

Há, nos estudos de Silva (1998), alusão ao componente no. 4 "Desenvolvimento Institucional" que também demonstra a importância que a descentralização tem dentro do projeto. O primeiro objetivo do componente apresenta a política do Paraná de descentralização gradual da responsabilidade administrativa tanto em favor das escolas como aos municípios o que acarretou uma série de mudanças importantes na administração do sistema de ensino. No âmbito estadual, a SEED assumiu um papel maior de supervisão financeira e do controle da qualidade do sistema e isso criou uma necessidade de acesso e divulgação de informações confiáveis e rápidas. Os diretores de escolas e os municípios estão, por sua vez, assumindo um papel mais administrativo do que tinham no passado, um papel para o qual nem sempre estão bem preparados.

"A principal meta desse componente do projeto é melhorar os instrumentos, a capacidade e os incentivos, tanto a nível estadual como municipal" (Projeto de Qualidade no Ensino Básico do Paraná, 1994:28). 
A autora considera que, diante disso, pode-se apreender o sentido da descentralização que o Banco pretende estimular com este programa, isto é, uma descentralização da SEED com participação das escolas, outra, do Estado com participação do Município, reservando-se ao Estado e à SEED o encargo de supervisionar as finanças e controlar a qualidade do sistema.

A questão da autonomia da escola e as implicações dessa proposta no contexto das escolas públicas estão presentes no âmbito das políticas educacionais promovidas no Estado do Paraná, principalmente a partir da última década. Tal proposta, pode assumir diferente significado, o que, por sua vez, acaba

“... permitindo práticas totalmente adversas das defendidas pelas organizações dos trabalhadores em educação que lutam pela ampliação da oferta do ensino público, gratuito e de qualidade no Estado" (HIDALGO, 1999:12).

Para garantir o modelo que a SEED propaga, as escolas recebem documentos que indicam que tipos de gestão devem desempenhar. Além disso, a SEED tem proporcionado cursos para gestores escolares em Faxinal do Céu ${ }^{51}$, não só para diretores, mas também para professores e até para os presidentes de APMs. Muitos têm participado desses cursos freqüentemente. A capacitação empreendida na "Universidade do Professor", em Faxinal do Céu, contemplava cursos que objetivavam levar às escolas a lógica de uma política educacional neoliberal.

${ }^{51}$ Faxinal do Céu localiza-se no distrito de Pinhão - PR., aproximadamente $400 \mathrm{~km}$ ao Sudoeste de Curitiba, também conhecido como Universidade do Professor que tem por objetivo "capacitar" profissionais da rede estadual de ensino do Paraná. Trata-se de uma estratégia de convencimento e cooptação ao modelo de política educacional empreendido no PR. Segundo Sapelli (2003), "os eventos em Faxinal eram verdadeiros "circos" com direito a "palhaços" e tudo! Chegaram até a achar que nunca havíamos sido tão bem tratados" (p.137). A crítica da autora é válida, pois os cursos oferecidos em grande parte versavam sobre a motivação e sensibilização, ou seja, enfatizavam o psicologismo. "Podemos até nos referir a Faxinal como centros de ilusões, pois lá docentes aprendem que diretor é gerente, alunos são clientes, a vida é uma competição, e que o sucesso na profissão deve ser alcançado pela força interior, individual" (APP/ Sindicato, 2002b, p.13 apud. Sapelli, 2003:137). Se entendermos que o modelo de gestão proposto pelo governo pauta-se na GQT (Gerência de qualidade total) percebe-se que a sensibilização representou a construção da motivação necessária para que os trabalhadores respondessem aos chamados do governo Lerner para a reorganização da escola, não criando movimentos de resistência. 
Estudos sobre a política educacional do Paraná ${ }^{52}$ demonstram várias contradições entre o discurso e a prática: Que autonomia é essa que impõe projetos como o PQE e PROEM sem a participação da comunidade escolar na elaboração, discussão e processo de negociação com os financiadores? Que autonomia é essa que força as escolas a elaborarem seus projetos político-pedagógicos em curto espaço de tempo, comprometendo a discussão, e dentro dos moldes da SEED? Que autonomia é essa, se as orientações da SEED são apresentadas como "sugestões" e disfarçadas com roupagem deslumbrante, mas na verdade são imposições que, caso não forem cumpridas, resultarão em punição das escolas, principalmente na supressão de verbas? Que autonomia é essa em que há restrições ${ }^{53}$ que favorecem os interesses e necessidades do processo de acumulação flexível do capital e não a satisfação dos interesses e necessidades da maioria da população?

O quadro abaixo demonstra uma síntese comparativa da política educacional no Paraná, entre os governos de Roberto Requião (1991-1994) e Jaime Lerner (19952002), os quais intensificaram o processo de reestruturação da política educacional do Paraná, a partir das determinações dos organismos internacionais.

\footnotetext{
52 Ver HIDALGO, Ângela Maria. Tendências contemporâneas da privatização do ensino público: o caso do Estado do Paraná. Dissertação de mestrado em educação PUC/SP, 1998; DEITOS, Roberto. O PROEM e seus vínculos com BID/BIRD: os motivos financiadores e razões ideológicas da política educacional paranaense para o ensino médio e profissional. Campinas/SP, 2000. Dissertação de mestrado em educação, UNICAMP; GONÇALVES, Maria Dativa de Salles. Autonomia da escola e neoliberalismo: Estado e escola pública. Tese de doutorado, PUC/SP, 1994; HIDALGO, Ângela Maria e SILVA, lleizi Luciana Fiorelli (orgs). Educação e Estado: As Mudanças nos Sistemas de Ensino do Brasil e Paraná na década de 90. Londrina: Ed. UEL, 2001; CZERNISZ, Eliane Cleide da Silva. "Gestão democrática" da escola pública: Um movimento de "abertura" da escola à participação da comunidade? Dissertação de mestrado em educação. UEM-Maringá, 1999; SILVA, lleizi Luciana Fiorelli. Reforma ou contra-reforma no sistema de ensino do Estado do Paraná? Uma análise da meta de igualdade social nas políticas educacionais dos anos 90. Dissertação de mestrado em educação. USP-São Paulo, 1998; SANTOS, Jussara Maria Tavares Pugliesi. As políticas governamentais para o ensino fundamental do Paraná diante dos preceitos da constituição. Tese de doutorado em educação. USP, São Paulo, 1998.

${ }^{53}$ As restrições e as limitações devem existir, porque, caso contrário, pode-se cair num nautonomismo, ao qual nos referimos no item 5.3 deste trabalho. O problema resulta nos princípios norteadores dessas restrições e limitações.
} 


\section{QUADRO III: QUADRO COMPARATIVO ENTRE A POLÍTICA EDUCACIONAL DO GOVERNO DE ROBERTO REQUIÃO E A DE JAIME LERNER}

\begin{tabular}{|c|c|c|}
\hline & $\begin{array}{|lll|}\begin{array}{l}\text { GOVERNO } \\
(1991-1994)\end{array} & \text { DE ROBERTO REQUIÃO } \\
\end{array}$ & $\begin{array}{l}\text { GOVERNO DE JAIME LERNER } \\
(1995-2002)\end{array}$ \\
\hline $\begin{array}{l}\text { Formas de Gestão do } \\
\text { sistema de ensino }\end{array}$ & $\begin{array}{l}\text {-Início de negociações com os organismos } \\
\text { internacionais; } \\
\text {-deslocamento da proposta de cunho } \\
\text { democrático, mesmo sob influência capitalista, } \\
\text { para propostas de cunho mercadológico; } \\
\text {--Busca pela participação da comunidade nos } \\
\text { assuntos escolares; } \\
\text {-Mobilização e alocação adicional para a } \\
\text { educação; } \\
\text {-Enfoque setorial e definição de políticas e } \\
\text { prioridades baseadas na análise econômica; } \\
\text {-Municipalização do ensino fundamental, que } \\
\text { se reduz à desconcentração/transferência de } \\
\text { responsabilidades, mediante convênio de } \\
\text { cooperação financeira entre o governo do } \\
\text { Estado o os municípios; } \\
\text {-Aumento do número de séries do ensino } \\
\text { médio profissionalizante, legitimando a } \\
\text { preocupação reducionista de formação para o } \\
\text { mercado de trabalho; } \\
\text {-descentralização da SEED que transfere aos } \\
\text { NRE tarefas administrativas; } \\
\text {-Princípios norteadores: gestão democrática, } \\
\text { comunicação direta, projetos pedagógicos e } \\
\text { avaliação do desempenho escolar; } \\
\text {-busca pela melhoria da qualidade do ensino } \\
\text { através de procedimentos meritocráticos } \\
\text { associados com a intervenção do Estado; } \\
\text {-Marcado pela transição e alternância de } \\
\text { procedimentos com maior intervenção do } \\
\text { Estado e procedimentos individualistas e } \\
\text { mercadológicos na política educacional e na } \\
\text { forma de gestão do sistema. }\end{array}$ & 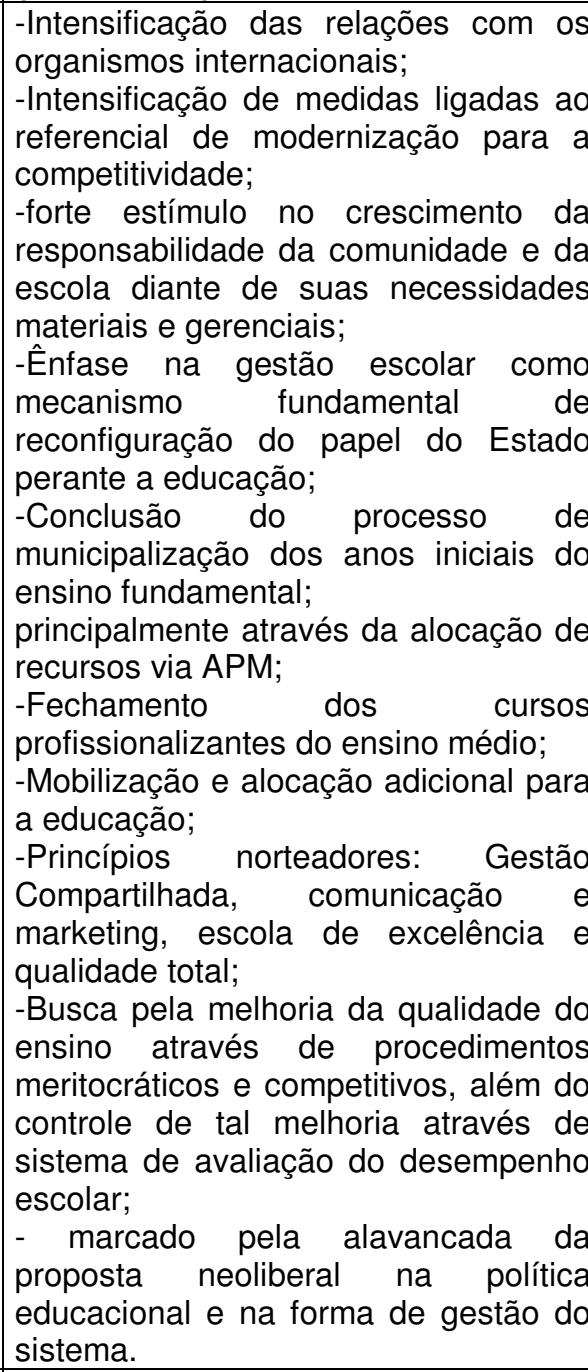 \\
\hline $\begin{array}{l}\text { Formas } \\
\text { financiamento }\end{array}$ & $\begin{array}{l}\text {-Repasse de verbas aos municípios que } \\
\text { assumiram os anos iniciais do ensino } \\
\text { fundamental; } \\
\text { - Verbas da SEED distribuídas às escolas } \\
\text { conforme o número de alunos, os turnos de } \\
\text { funcionamento, a área construída e a idade do } \\
\text { prédio; } \\
\text {-Início da negociação com o Banco Mundial } \\
\text { para empréstimo e fechamento do acordo; }\end{array}$ & $\begin{array}{l}\text {-Repasse de verbas para os } \\
\text { municípios que se responsabilizaram } \\
\text { pelos anos iniciais do ensino } \\
\text { fundamental; } \\
\text {-Utilização do empréstimo do BM para } \\
\text { o programa de melhoria da qualidade } \\
\text { do ensino Básico; } \\
\text {-Elaboração e utilização de } \\
\text { empréstimo do BID para o PROEM; }\end{array}$ \\
\hline
\end{tabular}




\begin{tabular}{|c|c|c|}
\hline & $\begin{array}{l}\text {-Incentivo á autonomia das escolas para buscar } \\
\text { meios de conseguir recursos na comunidade. }\end{array}$ & $\begin{array}{l}\text {-Empréstimo do BIRD para execução } \\
\text { do PQE, no qual os investimentos } \\
\text { destinavam-se para: material } \\
\text { pedagógico, treinamento de } \\
\text { professores, melhoria da rede física e } \\
\text { aumento do acesso, desenvolvimento } \\
\text { institucional e estudos e avaliação; } \\
\text {-Incentivo às parcerias das escolas } \\
\text { com a comunidade e com instituições } \\
\text { não-estatais na manutenção das } \\
\text { escolas; } \\
\text {-Incentivo aos C.E. e as APMs para } \\
\text { buscarem outras fontes de recursos } \\
\text { não-estatais. }\end{array}$ \\
\hline $\begin{array}{l}\text { Formas de gestão das } \\
\text { escolas }\end{array}$ & $\begin{array}{l}\text {-Programa de autonomia da escola } \\
\text { denominada de escola cidadã; } \\
\text {-Criação dos Conselhos Escolares, enquanto } \\
\text { condição para que as escolas recebam os } \\
\text { recursos; } \\
\text {-Fortalecimento da direção da escola; } \\
\text {-Modificação nos regimentos escolares, } \\
\text { minimizando as intervenções extremamente } \\
\text { autoritárias; } \\
\text {-Estímulo à participação da comunidade nas } \\
\text { necessidades materiais e gerenciais da escola; } \\
\text {-Tem como eixo a autonomia escolar, via } \\
\text { elaboração do P.P.P; } \\
\text {-início do estímulo ao estabelecimento de } \\
\text { convênios entre as escolas e instituições não- } \\
\text { estatais; } \\
\text {-busca pela "Escola Cidadã". }\end{array}$ & $\begin{array}{l}\text {-Gestão compartilhada da escola sob } \\
\text { forte influência da GQT; } \\
\text {-Reforço do papel do diretor na } \\
\text { administração da escola; } \\
\text {-Reforço do papel das APMs e dos } \\
\text { conselhos escolares na administração } \\
\text { e na busca de recursos para as } \\
\text { escolas; } \\
\text {-Estímulo à competição entre as } \\
\text { escolas através de premiações } \\
\text { mediante o desempenho nas } \\
\text { avaliações do sistema de ensino e dos } \\
\text { índices de reprovação das escolas; } \\
\text {-Modelo empresarial de GQT como } \\
\text { modelo de gestão das escolas; } \\
\text {-Forte estímulo e valorização, através } \\
\text { de premiação, dos convênios entre as } \\
\text { escolas e instituições não-estatais; } \\
\text {-Busca pela "Escola de Excelência". }\end{array}$ \\
\hline $\begin{array}{lr}\text { Formas } & \text { de } \\
\text { administração dos } & \text { decursos humanos }\end{array}$ & $\begin{array}{l}\text {-Crítica ao desempenho dos servidores } \\
\text { públicos, especialmente dos professores; } \\
\text {-Medidas populistas e paliativas quanto à } \\
\text { situação de servidores e professores; } \\
\text {-Correção dos salários pelos índices de inflação } \\
\text { mensal; } \\
\text {-Negociação com o sindicato mediante pressão } \\
\text { e recursos legais; } \\
\text {-Início da prática da premiação, incentivando a } \\
\text { competitividade entre as escolas; }\end{array}$ & $\begin{array}{l}\text {-Descentralização da contratação dos } \\
\text { professores, que passam a ser } \\
\text { contratados pelas escolas; } \\
\text {-Criação da agência Paraná Educação } \\
\text { para a administrar os recursos } \\
\text { humanos, inclusive as verbas públicas; } \\
\text {-Criação de outro quadro de carreira a } \\
\text { partir do Paraná Educação, que } \\
\text { extingue vários direitos e o concurso } \\
\text { público como forma primordial de } \\
\text { contratação; do sindicato, pouca } \\
\text {-lsolamento do de } \\
\text { negociação, medidas de de } \\
\text { enfraquecimento do sindicato, com } \\
\text { cortes no repasse das mensalidades } \\
\text { via folha de pagamento. } \\
\text { - Persuasão do funcionalismo através } \\
\text { de cursos com forte caráter de } \\
\text { divulgação da ideologia da } \\
\text { administração empresarial (Qualidade } \\
\text { Total). }\end{array}$ \\
\hline
\end{tabular}




\section{AS ESCOLAS ${ }^{54}$}

Para tentar apreender a essência da gestão compartilhada, imersas em alguns fenômenos escolares verificados no estudo de caso, pesquisaram-se duas escolas públicas em Londrina-PR, no segundo semestre de 2003, ano em que se iniciou o governo de Roberto Requião, porém, a forma de gerir as escolas ainda era aquela estabelecida nos anos anteriores.

Os critérios de escolha das escolas estiveram pautados pela classificação das escolas, ante as indicações do NRE, quanto ao atributo de Escola de Excelência; pelo perfil do diretor da escola, considerando-se seu caráter de liderança; e pela localização das escolas (central e periférica).

Entretanto, a escola que liderava o ranking de "Escola de Excelência" em Londrina não aceitou a presença da pesquisadora na escola sob a justificativa de que a escola é muito procurada para estágios e/ou estudos de caso e que a pesquisa poderia entrar numa "lista de espera". Diante disso, iniciou-se o diálogo com uma Escola de Aplicação que pode ou não ser considerada "de excelência". Do ponto de vista da comunidade ela é considerada de excelência por acreditar que exista uma qualidade de ensino superior em relação às demais escolas públicas (portanto bastante concorrida), mas do ponto de vista do NRE não é considerada de "excelência", pois não pratica as orientações participacionistas e privatistas emanadas da SEED. A escola se localiza no centro $^{55}$ da cidade e atende basicamente a classe média-baixa.

A segunda escola escolhida não possuía concorrência de vagas e não foi mencionada pelo NRE como integrante do ranking das Escolas de Excelência. Ela se localiza na periferia e atende uma população, em sua maioria, moradora das favelas vizinhas ao bairro no qual está localizada.

\footnotetext{
${ }^{54}$ Os nomes atribuídos às escolas são fictícios.

${ }^{55}$ A Universidade Estadual de Londrina possui duas escolas de aplicação. Uma localiza-se no centro da cidade e outra no câmpus universitário. A pesquisa pautou-se principalmente na escola do centro da cidade, seguindo o critério de escolha das escolas citado acima.
} 
Entretanto, notou-se que o NRE desconhece as características de tal escola, pois se houvesse um exame pormenorizado detectar-se-á que tal escola poderia ocupar um lugar melhor no ranking das Escolas de Excelência do ponto de vista do NRE, por apresentar um alto grau de alocação de recursos não-estatais e de voluntariado em suas atividades cotidianas.

Após o período de apresentação do projeto de pesquisa aos diretores das escolas escolhidas, foi iniciado um processo de visitas e de marcação de entrevistas com os profissionais da educação selecionados: o diretor, o supervisor educacional, o orientador educacional ${ }^{56}$, um funcionário de serviços gerais e dois pais participantes da APM e do CE.

As visitas foram feitas no mesmo período. À tarde visitava a Escola Estadual Domingas Guerreiro da Silva e, à noite a Escola Estadual Maria do Rosário Soares Brasil. Elas consistiram em acompanhar as atividades dos sujeitos escolhidos para serem entrevistados.

Houve um maior acompanhamento das atividades da Escola Estadual Domingas Guerreiro da Silva por ser ela a que apresentou maiores possibilidades de discussão e participação tanto da comunidade interna quanto externa. Com isso, participava-se de reuniões do CE e da APM, da equipe pedagógica e até mesmo de uma Assembléia Geral de Pais, o que não ocorreu na outra escola. Isso indicou duas questões importantes. Uma é que a Escola Estadual Maria do Rosário Soares Brasil realmente não demonstrou freqüência na utilização dos canais de participação possíveis numa instituição escolar e a outra é que a pesquisadora, por não possuir neutralidade no processo de pesquisa, acabou por se envolver mais numa escola do que noutra.

Mas, foram as entrevistas que apresentaram o maior número de elementos para a utilização das categorias de análise, porque nelas se relataram e exemplificaram práticas concretas vividas que forneceram elementos para a busca das possíveis essências e para a elaboração de um concreto pensado provisório.

\footnotetext{
${ }^{56}$ É Importante explicitar as funções do orientador e do supervisor educacional no Paraná, por diferenciarem-se, por exemplo, das deste e daquele no estado de São Paulo. Todas as escolas estaduais possuem os dois profissionais cada qual com sua especificidade. $O$ orientador educacional tem o papel de desenvolver trabalho com as famílias, de ser elo de ligação entre comunidadefamília-escola, de trabalhar mais especificamente com as situações-problema dos alunos, e de trazer elementos de todas essas funções ao currículo e ao projeto-político-pedagógico da escola. Ao supervisor escolar cabe a incumbência especificamente metodológica e didático-pedagógica sendo, com isso, desenvolvido trabalho principalmente com os professores. É ele que coordena a elaboração e reelaboração do currículo e do Projeto-Político-Pedagógico da instituição.
} 
As entrevistas, embora pensadas e estruturadas a priori, sofreram mudanças de acordo com a escola e com o nível de entendimento dos sujeitos entrevistados. Com isso, dependendo do desenrolar do diálogo, surgiram perguntas e respostas diferentes das que tinham sido estruturadas anteriormente, mas seguindo o escopo das categorias de análise selecionadas. 


\subsection{CARACTERIZAÇÃO DA ESCOLA ESTADUAL DOMINGAS GUERREIRO DA SILVA}

A Escola Estadual Domingas Guerreiro da Silva foi criada em 20 de junho de 1960, pelo Decreto Estadual n.. 30.178 , como anexo à Faculdade de Filosofia Ciências e Letras de Londrina. Ele funciona como órgão suplementar da Universidade Estadual de Londrina, vinculado ao Centro de Educação, Comunicação e Artes. Oferece Ensino Fundamental e Médio. Já ofereceu cursos profissionalizantes, de 1982 a 1997, a saber: Técnico em Laboratório de Prótese Odontológica e Técnico em Laboratório de Patologia Clínica.

A população atendida pela instituição apresenta perfil socioeconômico muito heterogêneo. São, principalmente, os filhos de funcionários e de professores da Universidade e de funcionários públicos. Infere-se que tal população pode ser classificada em classe média-média e média-baixa.

A parceria entre SEED e UEL proporciona, pelo menos neste aspecto, um status de excelência para a escola, pois algumas carências que uma escola pública estadual comum apresenta, não aparecem nesta Escola de Aplicação. Muitos serviços que estão sendo providos pela própria escola, no sistema público de ensino, nesta instituição são operacionalizados pela UEL. Isso pode ser percebido na entrevista com o diretor geral, quando lhe é perguntado como é a gestão da instituição:

"É, tem dupla gestão. A Universidade tem uma quantidade de recursos alocados para a escola e subsidia algumas atividades como, por exemplo, a reprografia. Então nós temos uma vantagem em relação às escolas que são geridas só pelo Estado. Da mesma forma o quadro de pessoal é dividido em pessoal técnicoadministrativo e de serviços gerais, os quais a UEL garante metade e o Estado proporciona os outros $50 \%$. Esse diferencial é fundamental para que a qualidade da escola esteja um pouco acima da média das demais. (...) as escolas com o mesmo porte nosso teriam 4 pedagogos, nós temos 8 . Isso é um diferencial tem que ser relevado. Do mesmo modo a Universidade contribui por exemplo, com o ensino de obras literárias e literatura para que recebe de outras instituições através de convênios, etc., então nós temos uma biblioteca um pouco melhor do que as demais escolas, nós temos acesso à rede via Universidade, nós temos a segurança que é a Universidade quem mantém, nós temos o privilégio ou a prerrogativa de que os projetos institucionais da UEL venham para a escola, nós 
temos acesso aos outros órgãos da Universidade, com maior facilidade que as demais escolas, por exemplo, Museu histórico, Casa de Cultura, Museu histórico, Hospital Universitário, Ludoteca, Hospital Veterinário, todos esse órgãos nós temos o privilégio de relacionamento. Também a Rádio Universidade nos apóia bastante, temos a Assessoria de Relações Universitárias, a ARU, a Comunicação Social da UEL...então tudo isso, é diferencial não é?

Entretanto, embora a escola seja de Aplicação (para os cursos de licenciatura da instituição), ela sempre esteve distante do Departamento de Educação ou de qualquer outra licenciatura da UEL. $O$ fato é que nos últimos anos a escola não atingiu o objetivo de aplicabilidade das ciências apreendidas no âmbito acadêmico. A última gestão temse empenhado para que a escola receba as licenciaturas da UEL e se comunique com elas.

A direção da escola não é eleita como o é nas demais escolas estaduais. $O$ diretor geral é um cargo de confiança e é indicado pela Reitoria da Universidade. $O$ diretor auxiliar é indicação do diretor geral.

O quadro de pessoal é composto por quarenta e seis professores, vinte e seis funcionários, duas orientadoras educacionais e uma supervisora educacional. A escola conta também com a APM e o CE.

A escola tem dois prédios de grande porte. Em um, que se localiza no câmpus da Universidade, funciona as séries iniciais do Ensino Fundamental. No outro, localizado no centro da cidade de Londrina, funciona o Ensino Fundamental, de $5^{\mathrm{a}}$.a $8^{\mathrm{a}}$. séries e o Ensino Médio. 


\subsection{CARACTERIZAÇÃO DA ESCOLA ESTADUAL MARIA DO ROSÁRIO SOARES BRASIL}

A escola estava localizada no Jardim Panorama na rua Pitangueira, 209, em prédio cedido pela Escola Municipal José Garcia Villar. Em agosto de 1991 a Escola Estadual Maria do Rosário Soares Brasil passou a funcionar em prédio próprio, construída em convênio entre a FUNDEPAR e a Prefeitura Municipal de Londrina. Instalou-se, então, na rua Rosa Branca, 200, Vila Ricardo. Ela atende o ensino fundamental e médio.

Este é um bairro pobre com várias favelas ao seu redor. A escola atende principalmente os moradores das favelas que sobrevivem de subempregos, de benefícios oferecidos pelos serviços de assistência social público e de ajuda voluntária não-governamental.

A escola conta com a diretora geral e uma auxiliar, uma orientadora educacional, três supervisores de ensino, duas auxiliares de biblioteca, trinta e quatro professores, três funcionários de secretaria, sete auxiliares de serviços gerais e um auxiliar para gravar e organizar o material da TV-Escola. A escola conta também com a APM e o CE.

Embora a escola se localize num bairro considerado "de risco", com um público também considerado em situação de vulnerabilidade, pelas suas condições de vida precárias, ela é limpa, com pintura nova, com recursos audiovisuais e uma quadra coberta. Toda a manutenção dessa infra-estrutura confortável é provida, principalmente, por recursos não-estatais.

Mesmo atendendo a um público que vive em condições de vida subumanas, a escola apresenta características de "Escola de Excelência”, nos moldes do governo de Jaime Lerner, considerando-se seu potencial para alocação de recursos que suprem as lacunas deixadas pelo Estado e com práticas de gestão de pessoal que seguem as diretrizes da GQT. 


\section{DEMOCRACIA, PARTICIPAÇÃO, GESTÃO ESCOLAR, AUTONOMIA E DESCENTRALIZAÇÃO: ANÁLISE DOS DADOS COLETADOS NAS ESCOLAS}

Foram selecionadas categorias de análise que nortearam tanto os estudos bibliográficos quanto o estudo de caso. Procurou-se selecionar os principais fenômenos e conceitos que constituem uma gestão escolar e sua relação com o processo de democratização do ensino público. Com isso, as análises dos dados coletados, nas escolas pesquisadas, estarão classificadas de acordo com tais categorias de análise: democracia, gestão escolar, participação, autonomia e descentralização.

A categoria de análise democracia constitui-se em importante elemento para respaldar a relação buscada entre os aspectos mais amplos e os mais restritos ao fenômeno escolar. Para tanto, faz-se necessário tender-se para um ideal democrático no qual haja o reforço da base popular. Isso, trazido para a discussão da política educacional, significa estimular uma participação da comunidade atendida pela escola, na qual se faz parte, se tem parte e se toma parte do processo de ensino e aprendizagem de seus alunos/filhos.

Para que uma instituição esteja em democratização é necessária a participação, conforme assinalado acima. Não uma forma de participação monitorada, que exclui poder de decisão coletiva. Pode ser ela representativa e/ou direta, mas o fim último é assegurar que os interesses da maioria prevaleçam.

Defende-se, contudo, um processo de democratização do ensino público tendo como reforço a base popular. Para isso, além de uma forma de participação da comunidade interna e externa nos encaminhamentos escolares, se faz necessário criar condições para a conquista da autonomia e da descentralização de poder.

A construção e o exercício da autonomia incentivam o pluralismo de idéias, o respeito às diferenças e a emergência de atores sociais criativos e responsáveis. 
Além disso, uma proposta de autonomia escolar exige um esforço descentralizador e desconcentrador de poderes e recursos. A priori, essas premissas são louváveis, conquanto sejam contextualizadas e imersas num conjunto de princípios comprometidos com os interesses da maioria da população.

Para tanto, a gestão escolar não deve ser verticalizada, fragmentada e "compartilhada" "57. Entretanto, pode-se verificar, nos estudos registrados nos tópicos subseqüentes, que numa mesma instituição existem práticas tanto tradicionais, como aquelas que herdamos do âmbito empresarial ${ }^{58}$, quanto de gestão democrática, na qual se prima pela horizontalidade nas relações e na busca coletiva por melhores condições para a educação e emancipação da comunidade atendida. Vejamos, então, como os mecanismos e estratégias do modelo de gestão compartilhada, implementados pela SEED no governo de Jaime Lerner, se traduzem nas práticas escolares; e, quais as reais possibilidades de fetiche e resistência ao referido modelo.

\footnotetext{
${ }^{57} \mathrm{O}$ conceito de compartilhada deve ser entendido a partir da ressignificação feita do termo, no qual o compartilhamento, em última instância, se traduz em compartilhamento no provimento das condições objetivas que a instituição demanda.

${ }^{58}$ Sobre o transplante do modelo de administração empresarial no âmbito educacional, ver FÉLIX, Maria de Fátima Costa. Administração escolar: um problema educativo ou empresarial. São Paulo: Cortez e Autores Associados, 1989.
} 


\subsection{DEMOCRACIA}

\subsubsection{ESCOLA ESTADUAL DOMINGAS GUERREIRO DA SILVA}

O que se observou foi que os entrevistados em sua maioria salientaram o processo de tomada de decisão coletiva como possibilidade de democratização, mas não fizeram relação desse processo com suas atividades na escola.Quando o fizeram, acreditavam ser tão distante tal possibilidade, parecendo até impossível de ser operacionalizada.

$\mathrm{Na}$ fala da orientadora educacional da escola pode-se confirmar tal paradoxo, pois, ao mesmo tempo que afirmava que "ser democrático é acatar a decisão da maioria", logo em seguida afirmou que "a filosofia da instituição deve ser acatada por todos os professores".

(...) Você tem que colocar certas posições do colégio, filosofia do colégio, conduta do colégio. Não é coisa que dá para ficar escutando a opinião de cada professor.

O exemplo abordado é bastante relevante, pois a denominada "filosofia" da instituição diz respeito a uma possível falta de construção coletiva do projeto políticopedagógico, que caso fosse debatido conseqüentemente poderia haver a possibilidade de a viabilização do exercício da democracia na escola. Considera-se que esse é um elemento crucial para a democratização da gestão da escola e do ensino público como um todo.

No discurso ela se refere à tomada de decisão coletiva. Na prática não aceita a opinião dos professores que não se coadunem com a denominada filosofia da escola, visto que esta já está pronta de "cima para baixo", portanto hierarquizada.

Disse a orientadora:

...Acho que têm pontos que são discutíveis e têm pontos que não são discutíveis. Existem ordens que a gente recebe do Núcleo que são coisas que têm que ser cumpridas, não dá para ser democrático nessa situação.

Confirma-se com isso, uma posição conservadora e reprodutora da orientação educacional da escola, que não questiona qualquer decisão imposta pelos órgãos superiores, assim como, no interior da instituição, não se deve questionar ou modificar o 
que já está posto. A coletividade, nesta perspectiva, está pautada numa solidariedade orgânica durkheimiana na qual cada um faz a sua parte de forma fragmentada, mas não se atingem os processos deliberativos.

Tal posição se confirma também na entrevista de um pai de aluno quando apresenta sua concepção de democracia, mas se queixa de uma participação monitorada $^{59}$ no CE e na APM. Monitorada porquê, neste caso, é controlada principalmente pela equipe pedagógica.

Quando a gente tem sugestões dentro do pedagógico, sempre tem alguém que barra, e a gente não consegue, sabe! Então, eu acho que isso é uma coisa que temos dificuldade.

Um outro pai entrevistado consegue perceber a dimensão política de um possível processo de democratização. Mas lhe falta clareza quanto à maneira de criação e utilização de estratégias para que se exerça a democracia na escola e, ainda, também não lhe está evidente se é necessário esperar que venham determinadas de "cima para baixo" tais estratégias.

Respondendo às questões sobre democracia na escola, o pai entrevistado ressalta o papel fundamental que aa ações participativas têm na viabilização de um processo de democratização, mas afirma que as amarras que a SEED estabelece já estão tão enraizadas que prefere agir com "ações compartilhadas" a esperar que a própria SEED crie os mecanismos necessários para tal processo. Para ele

...É uma utopia a gente pensar em torno de democracia da educação estadual.

Suas justificativas para tal crença, que inviabilizam a democratização da escola, são: 1) as determinações verticalizadas emanadas da SEED; 2) a descontinuidade de projetos por conta da alta rotatividade dos professores CLTs; e 3) a burocracia estatal que demanda seu desempenho satisfatório tanto em condições subjetivas quanto em condições objetivas.

Para a superação de tais amarras elencadas pelo pai entrevistado seria necessário, antes de tudo, um maior esclarecimento acerca do conceito de democratização escolar, já que é a partir de tal conceito que se desdobrarão mecanismos convergentes para tal superação.

Para o Diretor da Escola, os mecanismos utilizados para propiciar um processo de democratização da instituição seriam desde veicular as informações de tudo que

${ }^{59}$ Ver Licínio Lima, 2001. 
está acontecendo na escola, até abrir seu espaço físico para a realização de outras atividades que a escola venha a oferecer para toda a comunidade interna e externa, a fim de fomentar a participação, em princípio, em níveis e graus mais baixos ${ }^{60}$.

Existia um dilema na escola que ocorria quando se ressaltava a participação e considerava-se a necessidade desta também ser estendida à comunidade externa. Mas como abrir espaços de participação para a comunidade, se ela, muitas vezes, reproduz a ideologia dominante e não contribui para possíveis mudanças?

Tal preocupação parece ser válida, considerando-se que os interesses imediatos são priorizados em detrimento dos interesses comuns mais amplos. Entretanto, se não forem explorados os espaços de participação, se não se começar a discutir, por exemplo, assuntos pedagógicos com a comunidade, não se irá exercitar efetivamente a tão propalada democracia. Ela só é apreendida através do seu exercício constante, portanto, mesmo em condições não-ideais, é fundamental criar condições, desde a sala de aula até a gestão do sistema de ensino, para o exercício pleno da democracia e, para isso, o processo de participação em todos os seus níveis e graus é fundamental.

Outro ponto abordado pela Direção da Escola é a menção de que não existe democracia integralmente constituída, mas uma intenção em democratizar uma determinada instituição evidenciando-se, portanto, um processo. Nessa trajetória processual faz-se necessário criar as condições e mecanismos que proporcionem uma democratização da educação.

A Direção exemplificou dois encaminhamentos com dispositivos democráticos. Um dizia respeito à decisão no CE acerca da alteração do cálculo numérico da avaliação, tentando-se com isso sanar o problema de evasão no último bimestre. Outro dizia respeito à decisão em Assembléia Geral com os Pais sobre a escolha de turno para ofertar os anos iniciais do ensino fundamental, pois a $1^{\mathrm{a}}$. e $2^{\mathrm{a}}$. séries eram ofertadas pela manhã e a $3^{\mathrm{a}}$. e $4^{\mathrm{a}}$. séries eram ofertadas à tarde.

No primeiro caso, tal decisão foi feita no âmbito do CE, exercitando-se, então, uma forma de democracia representativa. O problema dizia respeito à evasão dos alunos, que se dava no último bimestre, depois que sabiam que já tinham atingido a média necessária para a aprovação. A decisão tomada foi a de alterar o cálculo de

\footnotetext{
${ }^{60}$ Os níveis e graus de participação que a pesquisa se pautou foram criados por Bordenave (1993). Ele criou uma escala para apresentar o grau de participação desde o menor até o maior, são eles: a informação, a consulta facultativa, a consulta obrigatória, a elaboração/recomendação, a co-gestão, a delegação e a auto-gestão.
} 
avaliação anual, atribuindo um maior peso no último bimestre ${ }^{61}$, sob a justificativa de que o aluno deve ter acesso ao conhecimento até o último dia de aula. Considera-se pertinente a preocupação da escola, principalmente da Direção, de que o acesso ao conhecimento deveria ser aproveitado ao máximo (nos 200 dias letivos) e constitui uma condição necessária para a democratização da educação. Mas pode ser relativizada questionando-se, no que se refere a relação entre quantidade e qualidade na escola e se os professores são capazes de criar situações motivadoras para a permanência dos alunos em sala até o último dia de aula e se tal permanência se reverterá de fato em aprendizado.

No segundo caso, o tipo de democracia exercitada foi a direta, já que toda a comunidade interna e externa foi incluída e com poder de decisão. A decisão tomada foi a de ofertar os anos iniciais do ensino fundamental nos dois períodos, o que se constituía uma democratização do acesso àqueles que precisavam de mais opções de oferta escolar para seus filhos.

Embora as decisões tomadas expressem diferentes graus de democracia e de participação (Bordenave, 1983:31), percebe-se que o fato de a escola se preocupar em instalar dispositivos democráticos para sanar suas dificuldades configurou-se um "estado de democracia", possibilitando, então, um processo de democratização.

\footnotetext{
${ }^{61}$ A alteração do cálculo para avaliação anual foi: $1^{\circ}$ e $2^{\circ}$ bimestres terão peso 4 , e $3^{\circ}$ e $4^{\circ}$ bimestres terão peso 6.
} 


\title{
7.1.2 ESCOLA ESTADUAL MARIA DO ROSÁRIO SOARES BRASIL
}

Nesta escola as definições e exemplificações sobre democracia estavam permeadas da questão da liberdade. Percebeu-se que houve confusões conceituais sobre a relação entre democracia e liberdade.

Em todas as entrevistas foi ressaltada a liberdade de expressão, de opinião e até mesmo de ação. Mas como o conceito de liberdade era pensado apenas sob o viés individualista, confundiu-se a idéia de liberdade com libertinagem e/ou "liberalismo. A diretora da escola expressou isso em sua fala:

\begin{abstract}
Se você não coloca um certo limite fica um monte de coisa errado e não dá para fugir desse sistema, pois nós já tentamos às vezes ser mais abertos e aí se perde um pouco de disciplina. Fica muito vago se você deixa muito aberto. Eu já tive amigos que tiveram experiências de deixar mais liberal e não conseguir, aí vêm as cobranças da sociedade: "Fulano não sabe dirigir a escola ou com fulano a escola ficou pior".
\end{abstract}

Diante de tal afirmação, percebe-se que a concepção de liberdade enquanto produção e conquista humana que transcende o estado natural do homem, trilhada histórica e processualmente fica comprometida. Deduz-se que tal comprometimento resulta da prevalência de uma concepção de liberdade mercadológica, instalada pelo neoliberalismo, em detrimento de uma concepção humanista e marxista.

Outro aspecto intrínseco a esta fala diz respeito ao comportamento do grupo no qual se pretende estabelecer relações democráticas, pois a intenção do líder (diretor) em democratizar as relações escolares pode não estar em consonância com a do grupo/equipe/comunidade com o/a qual se está trabalhando. Ou seja, pode existir uma postura democrática por parte do líder, mas esta pode ser respondida com um comportamento de expontaneísmo e/ou libertinagem do grupo/comunidade, visto que este (a) não foi educado(a) de forma a valorizar e utilizar, de maneira satisfatória, os mecanismos democráticos propostos.

As contradições podem ser percebidas quando as entrevistas entre equipe pedagógica e funcionários são imbricadas.

$\mathrm{Na}$ fala da diretora:

A escola funciona por que nós somos realmente uma equipe e eu acho que uma equipe faz o trabalho acontecer. Quando você começa a puxar mais de um lado, mais para o outro, tomando decisão sozinha, a coisa começa ficar falha (...). Então democrática seria repartir não só as alegrias, mas as decisões e o trabalho. 
Num primeiro momento, sua fala demonstra uma concepção sobre democracia que possibilita a coletividade. Entretanto, no decorrer da entrevista ela vai demonstrando o exercício de uma democracia "compartilhada", ressignificada e adaptada aos moldes neoliberais, pois, na realidade o poder de decisão é hierarquizado e a participação é acionada na execução de tarefas preestabelecidas e, principalmente, para alocar recursos por meio de festas, doações e parcerias com instituições privadas. O poder de decisão é dividido, no máximo, com a equipe pedagógica.

Todos os problemas da escola eu nunca tomei uma posição sozinha eu sempre tentei repartir muito isso com a supervisão e orientação (Diretora).

Com isso, uma democratização que a cada decisão exercite o diálogo, portanto a participação, fica muito comprometida nesta instituição. $E$ isso pode ser percebido na entrevista com o funcionário:

Aqui a direção fala: funciona de tal forma e não funciona. Às vezes não ouve o professor, não ouve o funcionário, então eu acho que tem que melhorar isso.

Tais posicionamentos da direção parecem refletiras orientações do governo de Jaime Lerner, que atribuiu à democracia um caráter de compartilhamento nos aspectos administrativos (na execução) e financeiros, continuando centralizado o poder de decisão. Conquanto, nesse molde, esta centralidade nas decisões seja mascarada e as pessoas tenham a falsa impressão de que estão decidindo coletivamente em virtude da eficiente alienação quanto ao aspecto político da gestão e pela ressignificação do conceito de participação que se reduz a um pretenso caráter técnico efetivada no governo de Jaime Lerner.

Nesta escola, o conceito de democracia, percebido pela entrevistadora, está bastante confuso. Ora oscila entre o extremo da libertinagem, como se democracia fosse sinônimo de expontaneísmo, ora explicita-se o caráter liberal da democracia em curso, sendo ela conceituada no modelo de gestão compartilhada imprimida no governo de Jaime Lerner.

Tal confusão conceitual é bastante propícia ao modelo de gestão compartilhada implementada no Paraná no governo em questão, pois, desta forma, os envolvidos na comunidade escolar (interna e externa) não têm condições de propor mudanças na política imprimida.

Com isso, verifica-se a ressignificação dos conceitos de democracia que se descola para o de compartilhamento; e de participação da comunidade, que teve seu caráter político esvaziado. E ambos configurados, principalmente, no provimento das 
condições objetivas para a comunidade escolar das quais o Estado do Paraná pretendia se eximir gradativamente.

\section{GESTÃO ESCOLAR}

\subsubsection{ESCOLA ESTADUAL DOMINGAS GUERREIRO DA SILVA}

No processo da gestão escolar têm-se atividades-meio e atividades-fim, explicitadas primeiramente por Lourenço Filho e, tempos depois, aprimoradas por Vitor Paro, as quais, em relação dialógica e articulada, proporcionam um determinado modelo de gestão escolar de acordo com os objetivos selecionados para serem perseguidos.

Tais atividades foram salientadas pela supervisora da escola quando ressaltou a necessidade de uma "interação entre os alunos, a equipe pedagógica e a direção acerca dos objetivos da escola".

Quando Ihe foi pedido para diferenciar "gestão democrática" de "gestão compartilhada", ela exemplifica apontando os limites e as possibilidades para uma concepção de gestão genérica. Os limites estão imersos, principalmente, nas orientações que vêm "de cima para baixo" determinadas pelo Núcleo Regional de Ensino (que transmitem as orientações da SEED) sem tempo e abertura para a necessária discussão sobre se tais orientações são cabíveis nos diferentes contextos e realidades. As possibilidades foram expressas com as brechas encontradas pela escola para propor coisas diferentes das que já estão postas, adaptadas às necessidades e realidade de seus contextos educacionais. Entretanto, o desvelamento de ideologias, as divergências e/ou convergências referentes a um ou a outro modelo de gestão não foram percebidos pela entrevistada.

Uma questão que foi percebida por todos os entrevistados foi a diminuição de recursos públicos no governo de Jaime Lerner.

Nós trabalhamos muito sem recursos. Então, a falta de recurso humano, a falta de recurso material e a falta de recurso financeiro fazem a diferença porque quando você tem recurso se pode administrar e fazer uma boa gestão, e quando não tem recurso fica difícil (supervisora da escola).

Já na entrevista com o vice-diretor da escola, percebe-se um maior esclarecimento, embora não tenha sido encontrada uma diferenciação clara e objetiva. 
Vou dar só um dado para você caracterizar bem o que é democracia numa gestão na escola pública no Paraná. Que tipo de responsabilidade o gestor da escola pública tem, se ele não tem autonomia para contratar o professor? Não tem autonomia, no caso, de gestão de pessoal, não tem autonomia de gestão de material, não tem autonomia para suprir as pequenas faltas que existirem nos dia a dia das escolas, pois o Estado paga coisa de $R \$ 1,20$ por mês/aluno para fazer face às despesas. Isso dá para você gerir alguma coisa? Então, eu acho muito complicado. (Vice diretor)

Pode-se concluir, segundo estes depoimentos, que para operacionalizar um processo de democratização na gestão da escola pública é necessário que haja investimento. Isso torna explícito que a proposta de gestão compartilhada do governo de Jaime Lerner minimizou gradativamente os recursos públicos para a educação, o que impedia que as escolas se tornassem de "Excelência" como foi estimulado pelo próprio governo. Desvela-se também a lógica de racionalidade técnica e financeira, propalada pelo neoliberalismo, com a qual se operacionalizam os programas de GQT, associando-se a busca pela melhoria da qualidade dos serviços educacionais.

Aparece uma contradição, não só no modelo de gestão do Paraná como também na política educacional imposta pelos organismos internacionais, de que a associação entre escassez de recursos e melhoria da qualidade do ensino são incompatíveis.

Um outro elemento, relacionado ao anterior, foi ressaltado pelo vice-diretor e dizia respeito ao estímulo para o trabalho voluntário e parcerias com ONGs como medida parcimoniosa em relação aos recursos públicos.

Eu acho que as parcerias que se pretendia no governo do Lerner, são primas também das perniciosas ONGs, também perniciosos "Amigos da Escola", também perniciosos voluntariados. Esse pessoal está desobrigando o Estado de prover o serviço público, isso aí é um erro na minha visão (vice-diretor).

Então, percebe-se que a gestão escolar ao invés de concentrar esforços em estratégias participativas e democráticas para discutir, por exemplo, de que forma as atividades-meio podem melhor servir às atividades-fim e qual o papel do Estado em viabilizar deliberações coletivas, a fim de que estas possibilitem a melhoria da qualidade do ensino público ela se limita a administrar a escassez e a alocação de recursos, para, no mínimo, manter o que já está posto com pouco potencial de transformação.

O conceito de gestão escolar, num esforço de diferenciar entre a concepção democrática e a compartilhada, ficou bastante explícito na entrevista com o diretor geral da instituição.

Administração escolar democrática deve fazer com que a burocracia funcione no sentido de distribuir informação e conhecimento e buscar igualdade na oferta daquilo que a escola pode ofertar. Já a compartilhada, caracteriza-se principalmente quanto ao provimento das condições objetivas. 
O diretor demonstrou preocupação em salientar a relação entre as condições objetivas e subjetivas que interferem na operacionalização de uma possível gestão democrática. Ou seja, "de que adianta criar os mecanismos de discussão e deliberações coletivas se isso implica, como contrapartida, uma autonomia de gestão financeira que não é viabilizada pelo Estado?"

Outro elemento salientado e que interferia diretamente em tal operacionalização era a pouca resistência encontrada na comunidade escolar em se opor ao que vem predeterminado pela SEED. Assim, as diretrizes curriculares e demais determinações que chegavam nas escolas eram absorvidas na íntegra, segundo o entrevistado.

Ele também demonstrou preocupação em conquistar uma autonomia que viabilizasse a tão desejada gestão democrática e relatou, em linhas gerais, o processo de implementação do modelo de gestão de Jaime Lerner, com base em sua experiência o qual vem confirmar premissas anteriores.

Tal modelo, segundo o entrevistado, atribuiu papel fundamental ao diretor da escola: como é ele a autoridade que se relaciona diretamente com a SEED e com o Núcleo Regional de Ensino (NRE), então, é ele quem vai definir se aceita passivamente ou não as orientações recebidas, influenciando a escola com sua compreensão. Por isso, além dele ter recebido um (falso) poder no NRE, foi executado um programa de formação com os diretores e membros da $\mathrm{APM}^{62}$, em Faxinal do Céu - Universidade do Professor, sobre o modelo de gestão proposto como forma de incorporação alienada ${ }^{63}$, para posterior propagação de tal modelo nas escolas. Outra prática que ilustra bem tal investida neoliberal do governo Lerner foi o sistema de premiação para a gestão da escola que apresentasse os melhores resultados. Aliás, tal prática competitiva, que imprime um caráter mercadológico na educação, e mais especificamente na gestão escolar, foi inaugurada com Fernando Henrique Cardoso, com o "Prêmio Nacional de Referência em Gestão Escolar',64.

\footnotetext{
${ }^{62} \mathrm{O}$ fato de se convidar a APM e não o CE denuncia uma preocupação direcionada à questão financeira, já que há algum tempo ela vem exercendo atividades reduzidas a este aspecto. O próprio Estado do Paraná legitimou este reducionismo ao papel das APMs quando atribuiu a responsabilidade do gerenciamento dos recursos enviados pelo estado a ela, sob a justificativa de que está democratizando a gestão. Mas, como a verba liberada é insuficiente para cada escola, a APM concentra esforços em preencher as faltas e administrar a escassez de recursos.

${ }_{63}$ Semelhante alienação diz respeito ao aspecto político e ideológico porque as pessoas, no esforço de alcançar as metas traçadas em direção à "excelência" da escola, não percebem o processo de publicização, privatização e mercantilização da educação pública, entre outras questões sociais mais amplas.

${ }^{64}$ Esse concurso foi criado em 1998 pela CONSED, UNDIME, UNESCO e Fundação Roberto Marinho.
} 
O diretor que não possui a uma visão mais crítica sobre a desobrigação do Estado quanto às condições objetivas, concentrou esforços em estabelecer parceiras, organizar promoções, construir quadras com o dinheiro da comunidade, entre outras atividades que pudessem satisfazer as carências estruturais da escola; deixando, com isso, de mobilizar a comunidade interna e externa, junto à qual possui relativa liderança, para discutirem seus problemas, construírem coletivamente alternativas de superação dos mesmos, organizarem-se para pressionar os poderes públicos a fim de que atendam os interesses comuns e, com isso, conquistar gradativamente uma autonomia administrativa, pedagógica e financeira; viabilizando um processo de democratização da gestão escolar.

$\mathrm{Na}$ fala de uma mãe pode-se perceber uma outra contradição, pois em determinado momento ela ressalta a necessidade de cobrar dos poderes públicos providências para atender as necessidades da escola. Em outro, ela defende a cobrança da contribuição voluntária ${ }^{65}$, feita no início do ano pela maioria das escolas paranaenses.

Quando são analisadas as entrevistas realizadas com outros pais e com os funcionários, tal visão mais crítica fica cada vez mais distanciada.

Por outro lado, a escola pode considerar-se privilegiada por ter um diretor e um vice-diretor que estão, em princípio, desalienados quanto a esse modelo de gestão compartilhada implementado no governo de Jaime Lerner. O vice-diretor até esboça uma nova configuração da gestão nas escolas, a qual pode coincidir com a proposta, mais elaborada, de Vitor Paro. A proposta do vice-diretor seria:

Primeiro eu acho que não deveria ter a figura de diretor geral da escola. Deveria ter um colegiado que era o diretor, o secretário seria um diretor, o supervisor seria outro diretor, a orientadora seria outra diretora e o diretor seriam todos eles no mesmo nível e trabalhando de forma integrada, porque as escolas têm uma gestão compartimentada. (vice-diretor)

A proposta do pesquisador Vitor Paro seria também uma composição mais horizontalizada que propõe um Coordenador Geral de Escola, um Coordenador Pedagógico, um Coordenador Comunitário e um Coordenador Financeiro, formando, assim, um Conselho Diretivo. Paralelamente a este Conselho Diretivo continuaria a existir o Conselho Escolar, de caráter consultivo e deliberativo. Desse modo, a figura do

\footnotetext{
65 A contribuição voluntária é a cobrança de uma taxa que a escola faz no ato da matrícula. Tal contribuição, embora proibida por lei, foi estimulada exaustivamente pelo governador em questão.
} 
diretor, que hoje adquire centralidade, na gestão da escola, seria despojada de teor autoritário e dominador.

Muito embora a configuração de gestão escolar "ensaiada" pelo vice-diretor não atinja um alto nível de elaboração, como o é a do pesquisador, ela refletiu uma compreensão sobre a necessidade de superação do modelo predominante, que não é capaz de articular uma gestão democrática da educação pública.

Outro elemento, salientado pelo entrevistado, que interferia na operacionalização de uma gestão democrática era $\mathrm{o}$ aspecto pedagógico. $\mathrm{O}$ diretor ressaltou a necessidade de adotar a tendência histórico-crítica para que por meio da democratização do acesso ao saber, alcance uma democratização da sociedade como um todo.

(...) uma escola com conteúdos científicos e metodológicos adequados conteúdo único inclusive - faz com que as pessoas tenham apropriações qualitativas das diferentes áreas da ciência e da tecnologia e elas se darão bem em qualquer outra área, em qualquer outro lugar (...). (Diretor)

Explicita-se uma convergência com a crença de que a apropriação indiscriminada, de maneira crítica e reflexiva, dos saberes acumulados historicamente é essencial para a emancipação humana; muito embora tal condição escolar não garanta essa finalidade social.

Ainda com relação ao aspecto pedagógico, o diretor critica a adoção de um currículo estadual que permite ter uma parcela (25\%) dos seus conteúdos diversificada.

(...) Faz quatro anos que existe a obrigatoriedade dos 25\% da parte diversificada, e que se desdobrou em cerca de 1700 currículos diferentes, segundo a Secretaria Estadual de Educação. Por causa desses $25 \%$, então uma escola dá gestão empreendedora, a outra dá informática, a outra dá multi-meios, a outra dá filosofia, a outra dá sociologia. (...) Como a minha perspectiva ela é conteudista, então eu acho que a grade curricular pode ser fechada. Em nível de sistema, descentralizou-se também o currículo.

O alcance de uma democratização tem como uma importante premissa a questão curricular. Considerar as especificidades de cada localidade não deve traduzir -se em deixar uma porcentagem do currículo ao bel fazer das instituições, mas deve traduzir-se na garantia de que os conhecimentos mínimos necessários para a emancipação do homem sejam universalizados de forma que assegure os interesses comuns da maioria, considerando sua condição de dominação na sociedade capitalista contemporânea e a realidade dos espaços institucionais. 


\subsubsection{ESCOLA ESTADUAL MARIA DO ROSÁRIO SOARES BRASIL}

Nesta escola as informações, impressões e concepções sobre gestão democrática e compartilhada também foram bastante diversas e contraditórias. Numa mesma entrevista era possível notar tanto o comprometimento com o modelo de gestão compartilhada quanto a demonstração de resistência às orientações voltadas a esse modelo. Foi possível perceber, a partir dos resultados acumulados, que a escola apresentou um comprometimento marcante com o modelo de gestão compartilhada, por agregar um grande número de parcerias, trabalhos voluntários e a busca por uma qualidade do ensino por vias próprias.

Na própria caracterização da escola é possível perceber isso, pois numa escola de periferia que atende uma comunidade favelada e que, pelo exemplo de outras escolas em bairros considerados de "risco", poderia estar destruída, com vidros quebrados, "pixada" e ausência de materiais, muitas vezes roubados pela própria comunidade, ela se apresentou bastante conservada, com pintura nova, com computadores, televisores, vídeos e quadra coberta. Tudo isso como resultado do esforço de alocação de recursos privados. Nas entrevistas foram relatadas diversas parcerias com empresas privadas, como também muitos trabalhos voluntários foram desenvolvidos na escola em questão. Aliás, percebe-se que este é o ponto crucial que denuncia um maior comprometimento com o modelo de gestão compartilhada, embora fossem também relatadas atitudes e posturas contrárias e críticas a este modelo.

Nas questões que pretendiam verificar uma visualização, por parte da comunidade interna e externa, sobre o sistema de gestão estadual é que surgiram mais críticas por parte dos entrevistados. Mais de um entrevistado afirmou que as orientações por correspondência são em sua totalidade determinações que demandam uma rápida resposta/produção. As críticas diziam respeito às decisões preestabelecidas sem conhecimento da realidade da escola; à falta de tempo atribuída à operacionalização de tais decisões da SEED e à forma de relacionamento entre as instâncias deliberativas superiores e a escola.

Toda documentação que vem a supervisão recebe. Alguma coisa que ela acha que eu deva participar até comenta (...). (...) Os documentos chegam em cima da hora. (...) Eu já cansei de pegar documento "vencido". Inclusive tiveram cursos que quando chegaram aqui já tinha passado a data de inscrição.Tudo que vem da SEED ou é pra aquele dia ou já foi. (...) Então eu acho que o sistema é todo falho. (Orientadora Educacional) 
É interessante ressaltar uma contradição, percebidaa partir da entrevista, que a SEED pratica no processo de implementação do modelo de gestão compartilhada. Diz respeito à incoerência entre o discurso e a prática e denuncia a fragilidade do conceito de democracia inerente ao modelo de gestão escolar proposto: cobra-se das escolas um trabalho coletivo, participativo e autônomo e, no entanto, o governo estabelece determinações verticalizadas e autoritárias. Quando é solicitada uma discussão prévia sobre um determinado assunto, não é oferecida carga-horária para semelhante debate, obstando-se, portanto, a um "estado democratizante" no processo de implementação de gestão proposta pela SEED.

Nota-se no depoimento da diretora da escola que esta angústia de estar cumprindo deveres formais que pouco acrescentam à qualidade do ensino, é também da Chefia do NRE no período do governo de Jaime Lerner. Tal responsável relata que não obstante, entre a escola e o NRE houvesse uma estreita relação, esta não era suficiente para superar os obstáculos, pois eles vinham da SEED. Esta demonstrava a ênfase na produção de dados estatísticos quando solicitava um exagerado número de relações de índices e matrícula, de aprovação, de desistência, etc.

A Qualidade Total foi colocada, mas a escola não é como uma empresa que se lida com números. (...) Na verdade o governo quer que a gente produza números: índice de aprovação, de desistência, de reprovação, matrícula inicial e matrícula final. (...) Então a escola de excelência talvez pra eles é manter essa qualidade do ensino através do controle dos números. (diretora da escola)

É de amplo conhecimento que a produção de dados estatísticos é essencial para o governo conseguir liberação de parcelas de empréstimo do Banco Mundial ${ }^{66}$. Mas os dados e índices estatísticos pedidos às escolas também serviam para promover a competitividade entre as escolas, já que eles eramn divulgados e tornavam público um processo de comparação entre as escolas, desconsiderando-se a especificidade de cada instituição e as práticas clientelistas que beneficiam algumas escolas em detrimento de outras.

Um aspecto ressaltado na fala acima diz respeito à incoerência da relação entre a ênfase nos dados estatísticos e a busca pela melhoria da qualidade do ensino.

\footnotetext{
66 Durante o governo de Jaime Lerner foram produzidos vários documentos com caráter avaliativo. Em 1995, 1996 e 1997 foram publicados Avaliação do Sistema, previstos no PQE, os quais continham: Programa de Avaliação do Sistema Estadual de Educação (1995), Relatóriode Avaliação do rendimento dos alunos e análise dos resultados (1995 e 1996), Relatório de avaliação do rendimento dos alunos (1997) e Exemplar dos materiais utilizados (1995-1997). Sobre a análise de tais documentos ver GORNI, Doralice A.P. Sistema Estadual de Educação do Paraná: qualidade e avaliação. Tese de doutorado. Universidade Estadual Paulista Júlio de Mesquita Filho, 1999.
} 
Denuncia também a dicotomia entre os fins de uma empresa e os de uma instituição escolar, resultando-se disso a concepção de qualidade. Ou seja, numa lógica empresarial-administrativa proposta no modelo de gestão compartilhada o conceito de qualidade pode estar relacionado à racionalidade técnica e à atenção nos resultados para análise da relação entre custo e benefício, mas numa concepção de formação de sujeitos reflexivos, o conceito de qualidade está relacionado a uma construção coletiva de estratégias para conquistar, processualmente, a melhoria da qualidade do ensino público com o devido investimento advindo do Estado.

Talvez a mais eficiente forma de implementação do modelo de gestão compartilhada no governo de Jaime Lerner tenha sido a formação continuada efetivada na Universidade do Professor -Faxinal do Céu. Foi lá que os entrevistados se apropriaram das palavras de ordem do modelo de gestão compartilhada e tiveram o superte ideológico necessário para a inculcação da proposta. As palavras de ordem, na qual algumas são carregadas de ressignificação neoliberal, são Qualidade Total, Excelência em Educação, autonomia, participação da comunidade, entre outras. $O$ suporte ideológico começa desde as condições materiais que a Universidade do Professor oferece (lindo jardim, chalés bem decorados, bom restaurante, atividades culturais e artísticas) até os cursos de motivação e auto-ajuda, ministrados por empresas privadas, que nada tem a ver com a educação.

As falas ora elogiavam tal maneira de formação continuada, ora criticavam. Elogiavam por terem contato com atividades diferentes, por terem ido a um espaço bonito e agradável e terem tido uma boa alimentação (quase um hotel!) e, criticavam por não haver aplicabilidade e retorno nenhum no processo de ensino e aprendizagem dos alunos. A sua não-aplicabilidade se deveu, segundo as entrevistas, à desconsideração do contexto e realidade das escolas e à falta de condições materiais que demandavam algumas propostas feitas nos cursos.

Outras medidas na política educacional do Estado foram explicitadas pelos entrevistados, tais como: a ausência de concursos públicos; a não-reposição salarial durante oito anos; a falta de tempo para discussão coletiva; a diminuição dos recursos públicos para as escolas; a prática clientelista que orientava a liberação de verbas para reforma das escolas no estado do Paraná e a retirada da eleição para diretores (que retornou no final da gestão). 
As medidas salientadas pelos entrevistados denunciam o não-compromisso do Estado do Paraná para com a melhoria das condições de trabalho nas escolas e, conseqüentemente, na melhoria da qualidade do ensino.

A Correção de fluxo, programa de não-reprovação nos últimos anos do ensino fundamental, foi mencionada nas entrevistas como forma de aligeiramento na formação e fator preponderante na diminuição da qualidade neste nível de ensino. Tal programa propunha, entre outras medidas, salas multi-seriadas, nas quais agregavam, numa mesma sala, alunos de $5^{\mathrm{a}} ., 6^{\mathrm{a}}$., $7^{\mathrm{a}}$. e $8^{\mathrm{a}}$. séries. A precariedade de condições, a desconsideração de objetivos político-pedagógicos e o estabelecimento de critérios estritamente quantitativos denunciavam que tal programa vislumbrava tão-somente a obtenção de dados estatísticos de aprovação no ensino fundamental. Esse tipo de prática se justificava quando se remetia ao PQE, o qual liberava as parcelas de empréstimos conforme a apresentação de resultados.

Uma demonstração de resistência levantada pela diretora da escola foi a instalação do EJA (Educação de Jovens e Adultos) no período noturno. O EJA era um programa que estava sendo conduzido principalmente pelo Município e o argumento do NRE de ensino era que a escola não poderia trazer uma modalidade de ensino municipal para a escola estadual. A diretora argumentou sobre a necessidade da comunidade, em que a maioria das famílias apresentava analfabetismo, e sobre a existência de salas ociosas no período noturno por conta da evasão diagnosticada no ensino noturno no período analisado.

(...) O estado me dizia que eu não podia trazer professores da prefeitura para cá. Mas era uma necessidade da comunidade e, além disso, eu tenho salas ociosas. E provei para eles que eu não tinha matrícula à noite, tanto é que depois encheu, e hoje eu tenho as oito salas funcionando. (diretora)

A direção da escola demonstrou compromisso com a comunidade atendida e disposição em atender uma de suas necessidades, o que não se percebe nos encaminhamentos dados pela SEED, pois a evasão no ensino noturno foi conseqüência das medidas desta gestão. Com o fim do ensino profissionalizante no ensino médio, extinto nesta gestão, e o estímulo à educação à distância, os alunos passaram a participar de outros programas de formação que custam mais barato ao Estado e que obtém maiores resultados num curto intervalo de tempo. Outro fator que contribuiu para a evasão foi a instalação da correção de fluxo, já assinalada. 


\subsection{PARTICIPAÇÃO}

\subsubsection{Escola Estadual Domingas Guerreiro}

Os canais de participação que a escola oferecia eram as reuniões pedagógicas, as reuniões de APM, as reuniões do C E, os conselhos de classe, as reuniões bimestrais com os pais e o grêmio estudantil.

Nesta escola, existia uma preocupação em utilizar, cada vez mais e melhor, os canais de participação da comunidade, o que não se observou na outra escola. A queixa da comunidade interna é com relação à falta de participação dos pais. Em virtude dessa queixa, a escola tinha procurado criar formas de superação de tal dificuldade. De um lado incentivou, principalmente por parte da direção, a participação dos pais nos canais representativos e, de outro, tem-se tentado mostrar aos pais a necessidade de sua participação.

A participação dos pais nas questões escolares de seus filhos tem sido muito discutida por vários pesquisadores ${ }^{67}$ que defendem a democratização do ensino público. Num primeiro momento, há que se pensar acerca das determinantes da participação ou da não-participação dos pais, para, a partir delas, criar alternativas de superação dos empecilhos. Num segundo momento, há que se pensar sobre qual a relação entre escola e família que se deseja.

Sônia, membro ${ }^{68}$ da APM e do CE, atribuiu a falta de participação à "falta de cultura" e ao "relapso" das famílias em relação à educação de seus filhos, culpabilizando-as pela sua suposta "falta de cultura" e por sua, também suposta, incompetência na educação de seus filhos. Esta parece ser uma inferência de senso comum que não analisa a família em sua totalidade de relações com os aspectos econômicos, políticos, sociais e culturais.

Nessa escola não pareceu que a organização institucional atuasse de maneira a dificultar a participação dos pais, pelo contrário, existe um esforço para que os canais de participação sejam cada vez mais "movimentados" e deliberativos. O que se pode salientar é que, historicamente, a escola não vinha utilizando, com a devida

\footnotetext{
67 Tais como Arroyo (1992), Camargo (1997), Paro (2000).

${ }^{68}$ Ressalta-se que nesta escola os representantes de pais membros da APM e do C.E. são os mesmos.
} 
importância, tais canais de participação. Somente a partir da gestão iniciada em 2003 é que se buscou essa perspectiva.

De acordo com as entrevistas, pode-se notar que a direção anterior não buscava fortalecer a participação da comunidade na gestão da escola e que a gestão (2003) tornou esta ação como um dos seus principais objetivos. No decorrer do texto poder-se-á perceber que as formas, graus e níveis de participação estão sendo estimulados e operacionalizados pela escola.

A falta de tempo e o cansaço eram os principais motivos, apontados pelos entrevistados, que justificavam a não participação dos pais. E o pior é que este é um problema social cuja solução escapa às medidas que se podem tomar no âmbito escolar.

Paro (1997) entende que as classes trabalhadoras precisam preocupar-se em se organizar para cuidar de seus interesses comuns e lutar por seus direitos de cidadãos e por melhores condições de vida e de trabalho. Propõe até uma alternativa legal que garanta a liberação do trabalhador, sem prejuízos salariais, para participar das questões escolares de seus filhos. A falta de informação, que pode ser caracterizada como um baixo (mas necessário) nível de participação, sobre seu potencial de pressão, de ação coletiva e sobre seu direito de reivindicação, impossibilita qualquer forma de reação dos pais à informação, seja ela de apoio ou de resistência. Um elemento diferencial em jogo é a possibilidade de tomar parte e não apenas fazer parte.

Entretanto, isso não significa que a escola irá cruzar os braços diante desse limite e se acomodar. Há que se criar as condições que contribuam para a superação de semelhante limite. Por exemplo, nessa escola a APM criou pelo menos duas alternativas paliativas para estimular a participação da comunidade: a veiculação de um “jornalzinho", que divulga a função e as atividades desenvolvidas pela APM ao longo de um bimestre, e o anúncio na rede de televisão local sobre a Assembléia Geral de Pais que iria discutir a "contribuição voluntária" que é pedida em todo período de matrícula9 . Tais encaminhamentos representam uma galgada de um nível mais baixo de participação, o da informação, até um nível mais elevado, o do poder de decisão coletivo.

\footnotetext{
${ }^{69}$ A direção da escola relata que, embora tal contribuição seja proibida por lei em vários estados, inclusive no Paraná, as escolas solicitam a "contribuição voluntária" por motivo de sobrevivência. Na escola pesquisada que não estimula e não "abre as portas" para o trabalho voluntário, esta contribuição se tornava imprescindível para a manutenção do colégio ao longo do ano letivo.
} 
Outra justificativa relatada pela falta de participação dos pais, que não representava nenhum esforço em compreender o problema em sua totalidade de aspectos, foi perceptível nas palavras da entrevistada mãe Sônia:

"É falta de cultura, eu acho um pouco mais de cultura e um pouco mais de
consciência. (...) É falta mesmo de cultura do povo brasileiro, porque os pais
acham que a escola é responsável pra educar seus filhos. Eles cobram do
professor". (mãe participante do CE e APM)

Precisamos _como propõe Paro (1997)_ fugir da crença de que a nãoparticipação se deve a um comodismo sem razão de ser, próprio da nossa tradição cultural. De acordo com o autor, numa sociedade em que a forma de relacionamento humano é basicamente autoritária, em todas as instâncias da sociedade, é de se esperar que haja dificuldade em levar pessoas a perceber e explorar os espaços participativos. Outra questão que pode ser analisada nesta fala é a culpabilização da família por suas carências, individualizando o fracasso e instaurando a ideologia da meritocracia favorável à política neoliberal.

A relação entre família e escola foi estreitada e um dos motivos, que se confirmou com a fala de uma mãe, era o jogo de "empurra" na busca de um culpado pelo fracasso escolar. Os pais culpam os professores que culpam as famílias e estas, o próprio aluno e assim sucessivamente. Um movimento inverso deveria mover a relação entre família e escola que se sustentaria na busca de objetivos comuns entre as duas esferas, ou seja, comunidades interna e externa deveriam unir-se para pressionar os poderes públicos a fim de proverem educação de qualidade para seus alunos.

Tal situação de inimizade entre essas esferas configura-se, entre outras influências, como um reflexo da competitividade na sociedade capitalista, que coloca em campos opostos cada segmento da população numa relação de cliente e empresa. O transplante dos princípios empresarias para a educação se apresenta nos fenômenos escolares.

No contexto da reestruturação do papel do Estado, a participação da população e a "horizontalização" nas relações interpessoais têm sido anunciadas como estratégias democráticas de governo. Entretanto, o que se observou nas escolas pesquisadas foi que essa participação imprimida pelo governo neoliberal é reducionista e vinculada apenas à busca de trabalhos voluntários que dêem conta de suprir as lacunas deixadas pelo governo. 
Esta estratégia política, muito enfatizada no governo de Jaime Lerner, ganhou uma aceitabilidade alienada ${ }^{70}$ pela comunidade escolar, principalmente pelos diretores e pais das APM. Isso se deve ao "excelente trabalho"71 de capacitação realizado neste governo com esses sujeitos em Faxinal do Céu.

A escola, nesse aspecto, demonstrou um movimento contraditório. O diretor geral demonstra clareza de princípios e de concepção sobre participação popular e acredita que a participação deva ocorrer não apenas na execução de tarefas, como tem ocorrido com freqüência em escolas públicas, mas principalmente nos processos de tomada de decisão. O que não significa que a escola proporcione entre seus partícipes (comunidade externa e interna) um contínuo tomar parte, existe sim uma rede de práticas em que mais se faz parte do que se toma parte.

$\mathrm{Na}$ prática, este diretor vivia pelo menos dois dilemas com relação a esse aspecto e exemplificou a prática de participação ora de forma reservada ${ }^{72}$ ora de maneira ativa.

Um deles era com relação ao trabalho voluntário. Seu desejo era conscientizar a comunidade de que a sua participação deveria dar-se no sentido de cobrar do governo as condições objetivas mínimas para uma educação de qualidade e não prover tais condições das quais o governo se eximiu.

Entretanto, de acordo com sua entrevista, quando assumiu o cargo, a escola já estava estruturada de tal forma que a contribuição voluntária dos pais, efetivada no ato da matrícula, era fundamental para a sobrevivência da escola ao longo do ano letivo.

Este foi assunto para duas reuniões de APM e uma Assembléia Geral com pais. Nessas reuniões puderam-se perceber posições distintas. Existiam posições totalmente contrárias à "contribuição voluntária" (apenas duas pessoas), outras se posicionaram a

\footnotetext{
${ }^{70}$ Alienada por não terem os sujeitos consciência dos reais objetivos do governo quanto a essa forma de participação principalmente com contribuições voluntárias (tanto com prestação de serviço quanto com doações) e execução de tarefas que não interfiram no curso da política.

71 Sobre a disseminação do modelo de gestão compartilhada com teor mercadológico e que, conseqüentemente, aposta no marketing e na divulgação como eficiente trabalho de implementação, ver SOUZA, Silvana Aparecida. Gestão escolar compartilhada. Democracia ou descompromisso? São Paulo: Xamã, 2001; e RECH, Pedro Elói. Faxinal do Céu: Universidade do professor: a redução dos conceitos de educação e uma ameaça à sua forma pública e democrática. Dissertação de mestrado em educação pela PUC-SP, 1999.

${ }^{72}$ A participação reservada, categoria criada por Licínio Lima (2001), situa-se, teoricamente, num ponto intermediário entre participação ativa e a participação passiva. "Caracteriza-se por uma actividade menos voluntária, mais expectante ou menos calculista, através da qual não empenha definitivamente recursos, aguardando eventualmente para tomar uma posição mais definida, ou quebrando-se pela posição de partida como forma de proteger outro tipo de interesses, de não correr certos riscos, de não comprometer o futuro..." (Lima, 2001:77).
} 
favor e outras, embora argumentassem que se deveria cobrar do Estado as condições objetivas que a escola necessita. Entretanto, disseram que a escola já estava tão dependente desta prática, que para sair dela seria necessário conscientizar a comunidade escolar do seu potencial para pressionar o governo e ao mesmo tempo pedir a "contribuição voluntária" que é tão essencial para a manutenção da escola, para, aos poucos, ir exigindo a presença do Estado no âmbito educacional.

O outro dilema que o diretor demonstrou foi com relação à participação dos pais em assuntos pedagógicos. O assunto educacional que deveria ser discutido no cotidiano escolar entre a comunidade interna e externa, também foi abordado pelo diretor. Disse ele:

“... a opinião dos pais, a questão individual e subjetiva não é sinônima de garantia de decisão certa, ou da decisão mais apropriada. Então, eu cito exemplos bestas, eu passo nas salas de aula e pergunto aos alunos: - vocês preferem ter um bom professor de matemática ou ter uma caixa de bombom toda a semana? Ou eu posso perguntar: - $\mathrm{O}$ que você gostaria que tivesse na escola? As respostas podem ser: sorvete de graça, chocolate de graça, ou pode ser professores com doutorado. Nem uma nem outra coisa eu posso atender. A outra razão é porque eu não concordo com nenhuma e nem outra decisão. Então há um dilema. Eu tenho resolvido, não está resolvido definitivamente, mas eu devo ampliar ao máximo as informações sobre o que está acontecendo. As pessoas devem saber o que está acontecendo em todas as esferas e o tempo todo, quando essas informações chegarem ao público e, esse público reagir contrariamente, de maneira poderosa a essa informação que ele teve, então ele vai procurar os mecanismos de alterar essa decisão se for o caso, ou a decisão ou de uma prática". (diretor)

Esta fala demonstra as contradições inerentes a uma prática que se pretende democrática. Em outras palavras o diretor disse que os pais, embora necessitem participar das questões escolares, não têm os conhecimentos mínimos que lhes possibilitarão pensar sobre tais questões. Portanto, suas decisões podem não contribuir para um processo de democratização do ensino, estando alheios ao fato de que só haverá aprendizado crítico e reflexivo, por parte deles, acerca dos assuntos escolares de seus filhos, pelo seu exercício. Ou seja, quanto mais os pais forem expostos à discussão de questões escolares, mais eles estarão aptos a tomar decisões conscientes. É uma construção baseada na práxis que necessita de uma mediação desalienada da hegemonia dominante como forma de assegurar que as decisões tomadas coletivamente não sejam mera reprodução de ideologias hegemônicas.

Outro aspecto que se pode ressaltar, neste caso, é com relação aos níveis de participação. Bordenave (1983) cria, em seu livro O que é participação, graus e níveis de participação. Para ele o menor grau de participação é o da informação, justamente 
aquele em que o diretor entrevistado está se pautando para iniciar um processo de formação de uma cultura de participação.

A direção, entre outras práticas, informa à comunidade as decisões já tomadas. Por pouco que pareça, isso configura uma certa participação que pode representar o início de um processo de elevação do nível de participação da instituição. Tal elevação se constituiria numa busca incessante para requintar a forma de participação através do exercício nos coletivos deliberativos. Para tanto, o autor enumera os passos: 1) formulação da doutrina e da política da instituição; 2) determinação de objetivos e estabelecimento de estratégias; 3) elaboração de planos, programas e projetos; 4) Alocação de recursos e administração de operações; 5) execução de ações e 6) avaliação dos resultados.

No modelo de gestão implementado no governo Lerner e percebido nas escolas pesquisadas há uma supervalorização dos níveis 4 e 5 e a camuflagem dos demais níveis, principalmente aqueles que demandam reflexão e argumentação.

Considerando-se que a realidade escolar é complexa e contraditória, explicita-se a necessidade de perceber que esses níveis não irão manifestar-se de forma unívoca e linear. Exemplo disso foi a veiculação, feita pela escola, através dos meios de comunicação (rádio e televisão), tanto para informar sobre decisões previamente estabelecidas quanto para convidar para Assembléia Geral de Pais a fim de tomarem decisões de interesses comuns. Portanto, havia diferentes níveis de participação, considerados válidos, já que também estimulas a participação representativa e direta dos pais construindo uma verdadeira democracia participativa.

$\mathrm{Na}$ fala da supervisora escolar do noturno é que se denuncia a forma fragmentada e verticalizada de comunicação entre a comunidade escolar interna. As determinações pedagógicas são feitas, principalmente, através de um mural.

... É feito de informações aqui na hora do recreio, é feita a participação através de mural. Então, tudo que é colocado lá é lido.

As determinações pedagógicas da escola perecem que ficaram prejudicadas, entre outras determinantes, por conta de uma visão restrita de educação e de gestão democrática que a supervisão escolar possuia e, principalmente, pela falta de condições de trabalho dos professores. No contexto atual que a maioria dos professores era contratada temporariamente, eles eram obrigados a trabalhar em mais de uma escola, prejudicando seu envolvimento com uma determinada instituição. 
Nunca, (...?) em nenhum momento no Colégio ainda nesses últimos... Um ano e meio, conseguiu reunir todos os professores da escola. Como é que se constrói um projeto de escola? Como é que se constrói...é objetiva, isso é condição objetiva. Outra condição objetiva, professor ele é tempo-parcial nas unidades, então $90 \%$ dos professores aqui são tempo-parcial, como é que ele participa efetivamente da construção e se engaja no projeto de escola? Se ele não pode...Se ele é parte da escola, não é todo da escola. (Diretor geral)

Com isso, fica comprometida a proposta de construção coletiva e processual do projeto político-pedagógico da escola, já que faltam as condições objetivas e subjetivas para que tal coletividade se crie e efetive. Pode-se salientar a pertinência destas condições para a política neoliberal instalada no Paraná. A fragmentação da categoria trabalhadora do professorado era uma das estratégias para que não se criassem as condições de questionamento e de pressão sobre o Estado.

Uma interpretação sobre participação um pouco mais precária, do ponto de vista acadêmico, é da funcionária da escola. Sua concepção de participação se reduz à participação nos eventos (festas e passeios) que a escola promove.

De tudo que é feito aqui na escola, todo mundo participa, até a gente funcionário e tudo. Se vai ter uma festa, se vai ter uma divulgação, se vai ter um evento, se vai ter um passeio, todo mundo está incluído, aí a gente veja, analisa quem vai, quem não vai atender, seleciona tantas pessoas pra tal horário, tal horário, ninguém fica de fora. ...A gente passeia com as crianças, por exemplo, amanhã as crianças terão almoço de confraternização com os professores porque eles estão encerrando aqui com a gente. Então a gente tem assim, vários tipos de eventos, que às vezes essa parte a gente participa sozinho, os pais participam, mas assim...Fora.

O tipo de participação exemplificado pela funcionária da escola, conquanto tenha suas pertinências, reduz-se a questões técnicas, desconsiderando a dimensão política da participaçã,o e a questões operacionais e não-deliberativas.

Ainda que não fosse de esperar que uma cidadã que, aparentemente, nunca teve experiências participativas em instituições tivesse uma compreensão mais ampla da participação; poderia ser o caso de, na escola onde está inserida, se estimular tal compreensão mais completa de participação através do seu exercício; o que não foi verificado na entrevista.

Denuncia-se, mais uma vez, que a lógica de gestão compartilhada está instalada na escola, ou seja, o esvaziamento da dimensão política e o escamoteamento do real objetivo de tal esvaziamento estão inerentes nesta perspectiva de participação. Outra questão é a alienação quanto ao aspecto político de tal participação, a qual esconde a desresponsabilização do Estado quanto ao provimento de condições objetivas de trabalho escolar. É interessante notar que cada profissional da escola ou pai usuário da 
mesma tem-se uma concepção de participação diferente de acordo com a especificidade na qual atua.

Com relação à concepção da orientação escolar ${ }^{73}$ no que se refere aos períodos vespertino e noturno, vê-se uma vertente psicologizada de participação. Em sua fala percebe-se que são feitos atendimentos individualizados para resolver situaçõesproblema, tanto com os alunos quanto com os pais destes alunos.

Por outro lado, esse profissional exemplificou uma forma de resistência da escola, mais especificamente da equipe pedagógica, à disseminação, em âmbito nacional, do "Dia da família na escola". O argumento destacado pela entrevistada pautou-se na necessidade de participação das famílias em todo o processo escolar de seus filhos, e na fragilidade de uma proposta de participação fragmentada e com teor voluntarista. Com isso, a escola ensaiava uma atitude que procurou viabilizar a construção e uma gradativa conquista, processual e contraditória, da autonomia escolar, ao optar por não instituir este dia na escola.

Contudo, posto que pratique atitudes viciosas e conservadoras, a escola também criou situações de cooperação. A forma de participação na escola e sua movimentação havia demonstrado um cenário propício para a reflexão coletiva e conseqüente surgimento de propostas transformadoras que desembocassem no alcance dos objetivos comuns, muito embora houvesse um esforço do Estado em ressignificar o papel dos canais de participação, vislumbrando uma prática que não contempla a tomada de decisão (ou são atribuídas tomadas de decisões sobre coisas que não interferiam na política imposta), mas canaliza um esforço, cada vez maior, no setor financeiro.

\footnotetext{
${ }^{73}$ A habilitação de orientação escolar, numa perspectiva crítica, descarta a antiga prática de orientação que faz atendimentos individualizados, sob a justificativa de que tal prática é psicologizada, meritocrática e, portanto, alienada das questões e dos motivos sociais mais amplos que estão imbutidos nas situaçõesproblema escolares. Mais detalhes sobre tal questão ver Selma Garrido Pimenta, 1991.
} 


\subsubsection{Escola Estadual Maria do Rosário Soares Brasil}

Os canais de participação que a escola oferece eram os mesmos que os da anterior, porém utilizados de formas diferentes, tanto no âmbito da perspectiva quanto no da prática, a saber: as reuniões pedagógicas, as reuniões de APM, as reuniões do $\mathrm{CE}$, os conselhos de classe, as reuniões bimestrais com os pais e o grêmio estudantil.

A análise da entrevista de uma professora da escola traz muitos elementos. O primeiro deles diz respeito à questão do trabalho voluntário. Ela exemplificou um projeto, denominado "Mãos dadas", no qual as comunidades interna e a externa eram convidadas a "adotar" um aluno para satisfazer suas necessidades.

...Por exemplo, nós participamos do "Projeto Mãos Dadas" que não só os
professores participam, mas a comunidade também. Escolhe-se um afilhado, a
gente geralmente escolhe um aluno carente (...) e trabalhamos com esse aluno,
não só dando presentes para ele (...), mas também um pouco de apoio, de
carinho que eles não têm. E esse projeto está dando muito certo aqui na escola e
a comunidade vem uma vez por mês no sábado para darmos a assistência que
for necessária ao nosso "afilhado". (professora)

O trabalho voluntário na escola é um tipo de participação que a escola estava utilizando exaustivamente e que merece um exame mais de perto. Ou, antes ainda, cabe questionar o porquê da professora ter começado a sua resposta sobre participação com esse projeto. Isso pode denunciar uma concepção reducionista de participação pertinente à política neoliberal e de sua conseqüente proposta de gestão compartilhada, pois tal fenômeno retrata o incentivo dado pelo governo do estado, através de documentos, orientações e formação continuada ${ }^{74}$, a um nível ou grau de participação alienada dos aspectos sociais que tal prática carrega implicitamente. Os de 1) responsabilizar-se por prover um serviço social que deveria ser ou continuar público, 2) de contribuir para a privatização e/ou publicização da educação formal brasileira e 3) de desqualificar os serviços prestados pelos voluntários na escola, o que acabou por diminuir a qualidade do ensino, já que exerciam práticas para as quais não possuíam formação.

\footnotetext{
${ }^{74}$ Exemplo disso pode ser apreendido através do exame do trabalho de mestrado de Pedro Elói Rech (1999), no qual ela afirma que nos seminários produzidos pelo governo Lerner não se enfatizou em nenhum momento a concepção de educação e de sua relação com a sociedade, mas desenvolveram-se cursos com ênfase na motivação, auto-ajuda, Gerência de Qualidade Total, entre outras temáticas que não discutiram a qualidade da educação estadual e suas premissas essenciais. Denuncia-se, com isso, uma inversão de prioridades.
} 
Recorre-se ao documento emanado na gestão de Jaime Lerner para confirmar o estímulo dado a esse tipo de trabalho na escola, através do objetivo explicitado no PQE (1994):

(...) realização de parcerias e criação de entidades jurídicas e físicas sem fins lucrativos para a integração de segmentos da comunidade junto ao sistema educacional, visando sua efetividade e satisfação da população.

Um outro aspecto relevante apontado pela professora diz respeito às formas de participação em escolas com características diferentes, ou seja, nas escolas centrais, no seu entendimento, os pais participavam e acompanhavam a vida escolar dos filhos; já nas escolas periféricas, que são mais pobres os pais só vinham à escola quando há festa, bingo ou sorteio de algum prêmio.

Nesse caso, pode-se inferir que as estratégias para estimular uma participação ativa podem ter vínculo com as condições socioeconômicas dos pais. O problema é engessar tais estratégias em moldes assistenciais, no caso de oferecer à comunidade alimentação ou premiação, e ficar preso a elas, sem vislumbrá-la como possível ponte para estimular uma outra forma de participação mais democrática. Ou seja, acredita-se ser possível a escola criar uma situação de encontro com as famílias na qual ofereça um coffe braek, por exemplo, propondo-se, em seguida, um debate sobre uma dificuldade comum encontrada no processo de ensino e de aprendizagem de seus alunos/filhos.

Outra consideração a ser feita sobre tal questão foi que a forma de participação exercida pelas pessoas foi sendo influenciada por crenças e concepções que os pais têm. Tais crenças e concepções são construídas historicamente, dependendo do ambiente em que viveram, o tipo de escolaridade que tiveram, de quais instituições fizeram parte, entre outras relações que estabeleceram. Contudo, os pais da escola periférica pesquisada, na qual a professora se baseou para fazer tal comparação, eram oriundos da favela com baixa ou nenhuma escolaridade, portanto, não apreenderam a valorizar a vida escolar. Se aprenderam, foi por conta da crença na educação como possibilidade de ascender socialmente, que se constitui num dos condicionantes ideológicos mais observáveis nos discursos das pessoas, e não por que a vivência escolar fez parte de suas vidas.

Quando a entrevistada é indagada sobre o funcionamento do C.E. e da APM fica clara uma prática muito mais técnica do que política. Ela diz que o C.E. é acionado quando a escola tem um aluno com problemas de indisciplina e ninguém mais 
consegue ter controle sobre a situação. Têm-se duas questões a pensar. Uma é a forma de participação que o C.E. da escola está praticando e a outra diz respeito à questão da indisciplina.

A primeira confirma o sucesso da política de gestão compartilha, implementada por Jaime Lerner, que atribuiu um papel aos canais de participação que não contemplaram decisões que gerassem mudanças na política proposta. A concepção de participação adotada está esvaziada até mesmo dos mais baixos graus e níveis de participação $0^{75}$, tolhendo veladamente a possibilidade de ir-se construindo uma prática participativa cada vez mais evoluída, do ponto de vista político.

O curioso foi perceber a existência de poder de decisão no CE, mas poder de decisão sancionador, punitivo, classificatório e com caráter de julgamento e não de empenho coletivo de construção de alternativas, a partir da análise dos vários aspectos que influenciam a situação-problema, para superação dos motivos que estavam alimentando tal indisciplina. Demonstra-se uma reprodução alienada dos mecanismos autoritários/punitivos instituídos pelo Estado, que a própria escola e a comunidade criticam.

A segunda foi outra questão tratada na escola de maneira alienada e reducionista. Alienada porque a comunidade escolar, tanto interna quanto externa, se apresentava, na maioria dos casos, alheia aos aspectos políticos, econômicos e sociais mais amplos que determinavam tal indisciplina em sala de aula, e, em conseqüência desta alienação, encontrava formas de superação do problema excludentes e reduzidas ao aspecto psicológico do aluno, o que caracterizava uma culpabilização do próprio aluno pelo seu fracasso, reiterando a ideologia do mérito.

O escamoteamento dos aspectos políticos, econômicos e sociais garantiam a alienação e a dominação consentida. Para isso, imprimiu-se uma forma de participação monitorada, que foi sendo praticada tanto pelo CE quanto pela APM. Isto denunciou um dos mecanismos neoliberais de minimizar o papel do Estado, devendo este buscar outras formas de alocação de recursos e um nível de controle auto-gestionado ${ }^{76}$.

\footnotetext{
${ }^{75}$ Bordenave (1983).

${ }^{76}$ Nos programas de Qualidade Total encontra-se o ideal que consiste em que todos são "colaboradores" da empresa, devendo, portanto, cuidar do trabalho dos colegas, não havendo a necessidade de gerente, pois todos devem cuidar do trabalho de todos. É uma forma de controle remodelada que, fugindo ao modelo anterior autoritário e verticalizado, apresenta-se, mascarada e sutilmente, como horizontalizada e democrática.
} 
O papel da APM foi-se limitando, nos últimos anos, à atividade financeira. Isto foi percebido a partir de algumas pesquisas ${ }^{77}$ desenvolvidas no Paraná e se confirmou nesta pesquisa. Fica explícito, na fala da professora e de uma mãe de aluno, que seu papel, na escola em questão, limitou-se à organização de festas e promoções.

$\mathrm{Na}$ mesma escola um outro ponto de vista deve ser analisado _ o da diretora divergiram substancialmente do da professora. Ela dizia que as decisões são coletivas, mas viu-se que os espaços para tais decisões estavam sendo utilizados nos moldes da gestão compartilhada, ou seja, na descentralização do financiamento e de ações, mas as decisões continuavam centralizadas.

Ao elemento da descentralização de tarefas e da alocação de recursos estava inerente a prática de parcerias que a escola estabeleceu. A diretora geral relatou parcerias com uma família de alto poder aquisitivo, uma escola particular de grande porte, uma universidade particular, uma ONG e duas instituições públicas. Verificou-se que as parcerias com o setor privado eram maiores do que as estabelecidas com 0 setor público. $O$ resultado de tais parcerias foi 0 provimento de condições objetivas/materiais das quais o Estado se abdicou.

Uma visão completamente diferente à da diretora, mas que acabou apontando para os mesmos resultados, foi a do funcionário da escola. Ele apresentou muita dificuldade em compreender as questões apresentadas, mesmo havendo um esforço em adaptar as perguntas à linguagem dele. A sua dificuldade em responder às questões denunciou a fragmentação do trabalho, a falta de comunicação e de visibilidade do funcionamento da APM e CE e a ausência de sua participação em qualquer espaço da escola que não seja sua sala. Este quadro poderia ser diferente se tal escola tivesse possibilitado a este funcionário um tipo de experiência institucional mais horizontalizado e participativo e, conseqüentemente, mais democrático.

Percebe-se, na fala de uma mãe de aluno, a prática punitiva e julgadora do C.E., além de se confirmar um poder de decisão insignificante, do ponto de vista político, quanto à escolha do uniforme, por exemplo. Há que se refletir até que ponto o poder de decisão sobre as características do uniforme significa uma prática participativa para a democracia.

Por um lado, infere-se que qualquer prática participativa seja ela na execução de tarefas preestabelecidas ou no cumprimento de função punitiva, configura, de uma

${ }^{77}$ Sobre isto ver HIDALGO, 1998 e CZERNISZ, 1999. 
maneira ou de outra, um estimulo a um processo democratizante nas relações escolares. Por outro lado, tais formas de participação podem ser consideradas: 1) reducionistas, pois se restringem à execução de tarefas e deixa reservado o poder de decisão aos grupos hegemônicos; 2) ressignificadas, pois se explora seu potencial técnico e se esvazia o aspecto político, e 3) monitorada, pois suas formas de atuação estão controladas e centralizadas na ideologia do Estado.

A escola em destaque apresenta características que convergiam para uma forma de gestão compartilhada, tais como empreendedorismo, versatilidade, assistencialismo e voluntarismo.

O saber que o Estado deveria sustentar a escola de fato sobressai nas falas de alguns entrevistados. Mas a justificativa por práticas privatizantes foi que não dá para ficar esperando. Ora, ao invés de concentrar esforços para pressionar o Estado e até mesmo mobilizar outros segmentos que têm os mesmos interesses para se juntarem numa luta comum, concentram esforços "empreendedores" causando uma cisão cada vez maior entre esferas pública e privada. A necessidade de despender esforços para 0 alcance de objetivos comuns é unânime, entretanto a variante diz respeito ao método utilizado para tal alcance que está atrelado a uma determinada concepção de sociedade, de homem e de educação. 


\subsection{AUTONOMIA}

\subsubsection{ESCOLA ESTADUAL DOMINGAS GUERREIRO DA SILVA}

A concepção de autonomia dos entrevistados estava relacionada à liberdade de expressão e de ação com um caráter mais individual que coletivo. Não foi conseguida uma concepção de autonomia aliada a uma prática social coletiva e participativa e conquistada gradualmente em meio a uma realidade complexa e contraditória. Mas foi possível perceber o quanto os sujeitos escolares ainda não estavam preparados para construir uma prática permeada por ações que viabilizassem a conquista coletiva da autonomia escolar e o quanto a política educacional do Paraná do governo de Jaime Lerner redesenhou e/ou ressignificou os mecanismos que possibilitassem o exercício da autonomia de maneira que não se descentralizasse o poder de decisão e que, mesmo assim, as pessoas pensassem que têm certa autonomia.

Os exemplos que os entrevistados deram para demonstrar o exercício da autonomia limitou-se a um poder de decisão que não incidia sobre uma mudança na política educacional paranaense, ou, se tinha, estava a favor dela. Por exemplo, na fala da orientadora educacional da escola foram relatadas as seguintes situações: 1) a semana da família na escola, 2) a escolha do livro didático, 3) a execução do Projeto de Matemática, que mais se assemelhava a uma aula de contra-turno, para alunos com dificuldades de aprendizagem, e 4) a autonomia financeira da APM. As primeiras podem ser classificadas como autonomia pedagógica e a última como autonomia financeira.

Para que se tenha autonomia pedagógica são necessárias também dosagens de autonomia administrativa e de gestão financeira, uma vez que interdependem. Exemplo disso foi a alta rotatividade de professores existente no governo Lerner por não ter havido concurso público e pela supervalorização dos contratos temporários. Como elaborar, numa perspectiva processual, O P.P.P. da escola com tal rotatividade docente? Que tipo de compromisso é possível estabelecer com a comunidade na qual o professor trabalha em três escolas, diariamente? Que tipo de aprendizagem é possível diante desse fenômeno? Estas e outras questões puderam conduzir a uma análise das reais condições dadas à escola para o exercício da autonomia as quais, como foi possível perceber, não facultaram o exercício de uma autonomia em que se apoiava na discussão coletiva, no respeito aos pontos de vistas das diversas funções existentes na 
escola e no empenho constante em defender os direitos educacionais da comunidade atendida pela escola.

“(...) A rotatividade de professores é uma coisa que está prejudicando o pedagógico, mas o governo não está nem aí. (...) Precisa substituir professor substitui, precisa rescindir contrato rescinde, sem pensar no pedagógico. Eu acho que isso é uma falta de respeito com os próprios alunos do ensino noturno, por exemplo, que tiveram cinco professores de português no mesmo ano". (Orientadora educacional)

Para que se construa e se viabilize uma autonomia pedagógica são necessárias as condições administrativas e financeiras, que não foram criadas. Pelo contrário, os principais espaços participativos (CE e APM) que poderiam possibilitar o exercício da autonomia foram remodelados e reorientados para administrarem a escassez e a precariedade de tais condições.

A escolha de livros didáticos para o ensino fundamental foi outra ação ressaltada pela entrevistada como prática autônoma da escola. O fato é que a SEED mandava uma lista de livros didáticos, na qual a escola deveria pautar-se para escolher os seus para os próximos anos, não podendo fugir dela. O que se pode deduzir é que isso não se configurou uma ação autônoma, por estar restrita ao que foi imposto pela SEED.

O terceiro exemplo foi o "Projeto de Matemática". Uma das professoras de matemática da escola se dispôs a ir ao contra-turno de aula para dar reforço aos alunos com dificuldades de aprendizagem nesta disciplina. Os sujeitos escolares denominaram isso de autonomia pedagógica, já que a escola está "livre" para desenvolver os projetos que quiser, desde que isso não acarrete mais gastos ao Estado. Nesse caso pode-se afirmar que existia uma autonomia pedagógica que se limitava e esbarrava na autonomia financeira. Além disso, existia o trabalho voluntário da professora que caminhava em direção às recomendações da SEED.

Tal exemplo de autonomia é justamente o modelo ressignificado que o governo Lerner imprimiu nas escolas, ou seja, não é uma autonomia de gestão financeira que previa o gasto de recursos públicos conforme decidido pela comunidade escolar de acordo com suas necessidades, mas uma autonomia na qual a escola está "livre" para suprir as necessidades que o Estado não atendeu deixando de dar as condições essenciais para a melhoria da qualidade do ensino público.

A supervisora da escola considerava que a escola tinha pouca autonomia pedagógica. Uma delas foi o exame admissional que era feito para alunos do ensino 
médio que vinha de outras escolas e que precisavam disputar uma vaga numa escola pública "concorrida".

$O$ fato de poder decidir entre os pares escolares alguma coisa é para se considerar atributo autônomo, mas a decisão tomada de classificar os "melhores alunos" reproduz uma prática excludente e competitiva que a sociedade conservadora contemporânea nos oferece.

Outra questão que dificulta a conquista da autonomia pedagógica era a má utilização da APM e CE. A primeira teve seu papel reduzido, principalmente no governo Lerner, no provimento de condições objetivas que a escola reclamava. A segunda, foi possível perceber, através da participação da pesquisadora em duas reuniões, que tratava-se de um esforço em explorar esse espaço para discutir não só questões financeiras, como faz a APM, mas questões pedagógicas também. O empecilho, neste caso, foi que não havia assiduidade e freqüência de reuniões, necessárias para discutir todas as problemáticas que a escola apresentava. Com isso, na maioria das vezes, não se discutiam assuntos escolares, de caráter preventivo e preponderante, referentes a todas as funções dos sujeitos escolares, mas situações-problema urgentes que eram remediadas com ações muitas vezes punitivas.

Com relação à autonomia financeira, nas palavras da entrevistada, a escola "tem uma APM muito forte" (...)! O dinheiro arrecadado por esse mecanismo participativo podia ser gasto pela escola da maneira que melhor entendesse. A última medida tomada pela APM foi a compra e implantação de catracas para controle de entrada e saída da escola. Para a implantação foi necessário que cada aluno pagasse seu cartão para o uso da catraca.

Ademais, o dinheiro enviado pelo Estado era "fechado", é a denominada, informalmente, "verba carimbada" e o dinheiro que a escola alocava sozinha podia ser gasto com "autonomia". Essa é a autonomia neoliberal à qual se referiu nessa pesquisa no capítulo 5.3 (p.74). Ou seja, não havia uma autonomia de gestão financeira com os parcos recursos estatais, mas sim um estímulo à cisão entre as esferas pública e privada nas escolas públicas.

Foi nesse contexto que se verificou a confusão conceitual entre autonomia financeira e autonomia de gestão financeira. A primeira pode significar uma "total liberdade" em angariar recursos para as necessidades escolares, demonstrando com isso, um certo teor nautonômico e uma característica tendenciosa para a, já 
mencionada, cisão entre as esferas pública e privada. A segunda traduz-se em liberdade para a escola gastar e gerir os recursos públicos de acordo com suas necessidades específicas.

Para confirmar a impressão da orientadora de "APM forte", foi necessário analisar as entrevistas dos pais que participaram de tal instância decisória. O pai Nivaldo, enumerando algumas responsabilidades financeiras da APM, afirmou que de todo o dinheiro arrecadado por ela também tinha-se que prestar contas ao Estado do Paraná.

“(...) Tudo tem que ter prestação de contas com o NRE. (...) Teve época que se não fosse a APM não tinha material de limpeza. (...) Nós pintamos o colégio por dentro todo ano e (...) o material de educação física é sempre a APM que tem que custear". (pai partícipe da APM e CE)

A cisão entre a esfera pública e a privada foi diagnosticada nessa escola, principalmente na outra, quando foram apresentados os seguintes dados sobre 0 financiamento da escola ${ }^{78}$ : quarenta e quatro por cento (44\%) dos custos da instituição eram executados pela APM, 29\% pela parceria com a UEL, 20\% pela FUNDEPAR, 4\% pelo PDDE (Programa Dinheiro Direto na Escola) e 2\% por receitas próprias. Pode-se, então, considerar esses $44 \%$ de custeio advindos da sociedade civil, mais especificamente da comunidade externa da escola, como origem privada.

Outro ponto a ser salientado nesta categoria de análise foi que nessa escola os depoimentos e exemplos dos entrevistados convergiram mais para a falta de autonomia pedagógica do que para a financeira e/ou administrativa, explicitando que o foco de reflexão dos sujeitos escolares estava relacionado com a melhoria da qualidade do ensino e com a busca por melhores condições de trabalho.

\footnotetext{
${ }^{78}$ Esses dados foram apresentados aos pais em Assembléia Geral em 30/10/2003, de maneira detalhada e transparente acerca das despesas e da receita da escola.
} 


\subsubsection{ESCOLA ESTADUAL MARIA DO ROSÁRIO SOARES BRASIL}

Nesta escola, os exemplos de autonomia, percebem-se, estiveram mais pautados no aspecto financeiro do que em outros. Isto pode significar que o foco de reflexão dos sujeitos escolares era muito mais assistencial, administrativo e financeiro que pedagógico. Ou seja, a preocupação estava voltada para as atividades-meio, ao passo que as atividades-fim eram deixadas para segundo plano, além de não se demonstrar a percepção da relação entre ambas.

Deve-se relembrar ao leitor a realidade de tal instituição e da comunidade atendida as quais não possuíam as condições mínimas de sobrevivência; talvez isso possa justificar a mobilização da comunidade interna da escola para tentar suprir as necessidades básicas.

(...) Muitas vezes eles não têm água perto nem sabão pra lavar a roupa, não tem um sabonete pra tomar um banho (...). (...) a gente trabalha com isso (...) quando visitamos a casa deles vemos que eles moram em 3, 4 até 5 numa caminha ou num colchão no chão batido (...). (orientadora educacional)

Diante dessa realidade foi possível perceber que o trabalho voluntário, principalmente o dos professores, estava muito apelativo nessa escola. Exemplo disso é o "Projeto Mãos Dadas", já citado na categoria participação, no qual se adotava um aluno. O "padrinho" e o "adotado" se encontravam uma vez por mês (no sábado) e o aluno recebia roupas e/ou uniforme escolar, material escolar e até cesta básica. $E$ de acordo com a orientadora educacional, quase todos os professores tinham "afilhado".

Acredita-se que tal fato possa ser um dos elementos explicativos para que 0 trabalho voluntário e o estabelecimento de parcerias (que suprissem as necessidades objetivas da escola e da comunidade atendida) se faziam com bastante empenho pela comunidade interna dessa instituição.

Entretanto isso não exime a escola da necessidade de explicitar o caráter ideológico e alienado de tais práticas, pois eram elementos-chave de uma gestão compartilhada que caminhou rumo à desresponsabilização do Estado para com as escolas.

A construção da quadra coberta merece uma atenção especial na análise. Primeira questão a ser pensada foi o próprio processo de negociação com o Estado direcionado a conseguir liberação de verba para a construção da mesma. De acordo 
com a orientadora educacional a escola pedia tal construção, mas nunca conseguia até que, por intermédio de um vereador (filho da vice-governadora de Jaime Lerner), conseguiu-se rapidamente sua liberação.

Nós pedimos na época para o vereador Roberto Belinati no ajudar. Então, a gente conseguiu que a Emília Belinati assinasse a liberação com bastante urgência. (orientadora educacional)

Atitudes clientelistas para a liberação de verba da SEED para construção e/ou reforma de escolas foi criticada pela própria diretora quando se referia à relação entre SEED, NRE e escola (no item de gestão escolar). Entretanto, foi aceita pela comunidade escolar uma prática clientelista do governo do Estado por ele atender seus interesses imediatistas.

Confirma-se que os agentes escolares dessa instituição estão sendo movidos por objetivos imediatistas em detrimento de objetivos coletivos obtidos somente pela busca da conquista da autonomia, o que pressupõe um processo de exercício participativo para atingir tais objetivos em longo prazo.

A segunda questão a ser pensada é o aluguel da quadra efetivado no período noturno e nos finais de semana para a comunidade externa, a dez reais a hora. É uma expressão explícita da publicização de instituição estatal e/ou da privatização do público no sistema escolar paranaense.

Finalizando-se o estudo sobre o aspecto financeiro da autonomia, percebe-se, pela fala das entrevistadas, que se confirmou nessa escola a preferência pelas formas de autonomia financeira em detrimento da autonomia de gestão financeira. A primeira seria aquela que a escola pode gastar o dinheiro que conseguiu recolher por vias próprias sem intervenção do Estado, embora seja necessária a prestação de contas. Enquanto a segunda diz respeito à autonomia de gastar e gerir a verba pública da melhor maneira que convier àquela instituição, de acordo com suas necessidades específicas, prática inexistente no sistema público de ensino paranaense, conforme evidenciaram os depoimentos. Com isso, fica desmascarada a concepção de autonomia tão enfatizada pelo governo Lerner, em seu modelo de gestão compartilhada.

Com relação ao aspecto pedagógico, a escola estava longe de conquistar a autonomia por ter uma prática muito explorada nas escolas paranaenses. Aquela que para se elaborar o P.P.P. havia uma reunião somente no início do ano na qual os 
professores se reuniam por área e reproduziam as orientações dos PCNs conforme recomendação do NRE.

(...) A gente faz aquela reunião no início do ano, pega todos os PCNs, separa os professores por área e fazem seguindo o PCN. (...) Você pode até tentar sair fora da linha, mas o NRE determina fazer de acordo com os PCNs. (supervisora educacional)

A supervisora escolar salientou que, na prática, não foi feita a relação do conteúdo do P.P.P. com os planejamentos e atividades dos professores. Existia um abismo entre o documento e a prática educativa.

Ele (PCN) é muito amplo, muito bonito (...) só que a gente não tem condições de colocar em prática dentro da nossa realidade porque envolve assim, por exemplo, projetos que às vezes tem que ter envolvimento de todo mundo, dos professores, da equipe.(...) Então no papel você faz o planejamento, segue aquele roteiro deles lá, mas na prática fica a desejar. (supervisora educacional)

O que não foi percebido é que esse abismo era resultado da forma como estavam sendo concebidos os P.P.P. da escola. Primeiro resultou, que, se não houver um esforço em buscar fazer do P.P.P. uma sistematização processual e reflexiva da prática educativa, ele continuará com esse caráter de terminalidade e será engavetado; segundo, que, se não estabelecer princípios norteadores de trabalho coletivo, de esforço em interpretar desalienadamente os PCNs, de proporcionar a participação da comunidade externa e de descentralizar poder- o que falta, segundo alguns entrevistados-, a proposta não terá consistência nem significado para os sujeitos escolares.

Por outro lado não se podem desconsiderar certos esforços em melhorar a qualidade do ensino por parte dos professores e da equipe pedagógica. Isso demonstrou o quanto a realidade é complexa e contraditória, sendo passível de um sem fim de práticas, nem tanto coerentes, como se percebeu pelo relato da professora e diretora de alguns projetos educacionais propostos pela escola os quais esbarraram na falta das condições objetivas necessárias para sua operacionalização. O principal empecilho era a falta de pessoal ou de estímulo financeiro aos profissionais da educação dispostos a desenvolver algum tipo de trabalho fora do horário de aula, desvelando a interdependência entre a autonomia pedagógica, a administrativa e a financeira. 


\subsection{DESCENTRALIZAÇÃO}

\subsubsection{ESCOLA ESTADUAL DOMINGAS GUERREIRO DA SILVA}

Esta categoria se relaciona com as demais, mas principalmente com a de autonomia que se caracteriza como condição primordial para sua operacionalização. Elas caminham ou deveriam caminhar juntas.

Do ponto de vista administrativo ficou explícito que inexistia uma política educacional disposta a utilizar a descentralização de poder como mecanismo para a democratização da educação pública. $O$ que se verificou foi a utilização da desconcentração de responsabilidades e, principalmente, do provimento de verbas, atribuindo-se a esse mecanismo a denominação descentralização.

$\mathrm{Na}$ entrevista com o diretor foram apontadas limitações normativas, ideológicas e práticas que inviabilizavam uma possível descentralização administrativa, financeira e pedagógica.

Um exemplo dado pelo entrevistado sobre a falta de autonomia administrativa é o Regimento Escolar que foi elaborado sob rígida orientação do NRE. As escolas receberam um documento chamado "Orientações para o Regimento Escolar" que já continha os títulos, os capítulos e a ordem.

Esse exemplo demonstra duas questões. Uma foi a total falta de autonomia administrativa escolar e a outra foi a atitude dos sujeitos escolares pronta em aderir a tal modelo de orientação passivamente. Isso foi motivo de discordância em uma das reuniões do conselho, dada a decisão do diretor de resistir às orientações do NRE e à posição da supervisora escolar, argumentando-se que, se não fosse feito conforme suas orientações, o documento seria devolvido à escola quantas vezes fosse necessário até que os ajustes fossem feitos conforme o ponto de vista do Estado.

“(...) A autonomia é bastante relativa e a transgressão daquilo que está estabelecido também é muito difícil. Nos últimos anos fizeram com que as pessoas desistissem de resistir porque você manda e devolvem, você manda de novo e devolvem novamente; você propõe e não é aceito. O resultado disso é a manifestação de um desânimo total em propor algo diferente do que o NRE orienta (...) (Diretor geral).

O mesmo ocorreu com o PPP e isso dificultou um processo de mudança na legislação a partir "de baixo", ou seja, da base, de quem estava "no chão da escola". 
Portanto, evidencia-se a falta de autonomia pedagógica e conseqüentemente a não-descentralização pedagógica.

Veja-se a propósito um exemplo: um entrevistado fez menção ao currículo para o ensino médio da instituição, no qual o item objetivo foi substituído por habilidades $e$ competências, conforme sugerem os PCNs. Tal substituição demonstrou uma adesão alienada à orientação da SEED, pois os sujeitos escolares não tinham clareza sobre os fundamentos que orientaram tal substituição e quais concepções político-pedagógicas estavam inerentes nesse modelo curricular, não sendo possíveis questionamentos e, quiçá, resistência. Uma das justificativas da adesão acrítica foi a necessidade dos professores trabalharem os conteúdos nos moldes que apontam o ENEM, já que a escola pretendia obter bons resultados com seus alunos. Mais uma vez remete-se à discussão o conceito de qualidade, que podem significar apenas "bons resultados" com base em uma perspectiva político-pedagógica neoliberal.

Com isso, as afirmações de vários autores ${ }^{79}$ de que o sistema nacional de avaliação representa uma forma de controle ideológico do Estado, embora este afirme conceder autonomia, se confirmaram. Confirmou-se, também, a falsa autonomia anunciada pelo Estado e a autonomia monitorada mencionada nessa pesquisa.

Do ponto de vista pedagógico a descentralização do currículo se expressa na diversificação de $25 \%$ do mesmo. Essa descentralização parcial curricular ocasionou a existência de aproximadamente 1.700 currículos diferentes no estado do Paraná. Tal parcela diversificada não assegurou o atendimento das especificidades da comunidade atendida, nem a elaboração descentralizada e autônoma do currículo paranaense. Acabou fragmentando ainda mais o ensino, dificultando a construção de um padrão único de qualidade para os atendidos pelo sistema de ensino público.

Outra demonstração de que as estratégias utilizadas pelo Estado anunciadas como descentralizadoras, mas que na realidade confirmam decisão centralizada, foi a alteração da porcentagem anual de freqüência dos alunos que não era mais por disciplina, mas o aluno devia ter $75 \%$ de freqüência no ano. Com isso, se o aluno resolvesse não assistir à aula de matemática, por exemplo, e obtivesse ao final do ano os $75 \%$ de freqüência no total, não se reprovaria por falta, comprometendo uma área do conhecimento. Isso demonstrou o quanto a escola ficava à mercê de medidas

\footnotetext{
${ }^{79}$ Autores como Dalila Andrade de Oliveira, Sandra Ma. Zákia L. de Souza, Romualdo Portela de Oliveira, Iria Brzezinski, entre outros.
} 
centralizadas que objetivavam a não-reprovação a fim de obter dados estatísticos e aligeiramento de formação, barateando os custos do Estado.

O diretor da escola manifestou o desejo que a instituição tem de adotar a média 7.0 para a aprovação. Neste texto não se tem a intenção de questionar tal desejo, mas sim de questionar a falta de autonomia e de descentralização de poder para as escolas pensarem, discutirem e decidirem, a partir da base, a viabilidade de tal mudança.

A capacitação docente foi criticada pelo diretor-auxiliar por ter sido centralizada em Faxinal do Céu. Isso dificultou uma mesma equipe escolar participar das capacitações continuadas ofertadas pelo Estado. No primeiro caso (formação continuada em Faxinal do Céu) era convocado um professor, ou dois, por escola, o que dificultava uma evolução conjunta da equipe escolar e, conseqüentemente, uma mudança de fato nas práticas escolares. O entrevistado defendeu uma maneira de formação continuada descentralizada por regiões podendo, com isso, abranger um número maior de profissionais e a continuidade no processo de formação.

Com esses exemplos, pode-se verificar que a tão propalada descentralização está longe de ser viabilizada pelos motivos político-econômicos, já bastante ressaltados nesta pesquisa, entre os quais, o de desconcentração de tarefas, de responsabilidades e de continuidade na centralização nas decisões administrativas, financeiras e pedagógicas. 


\subsubsection{ESCOLA ESTADUAL MARIA DO ROSÁRIO SOARES BRASIL}

A diretora reclamou do não-comprometimento de alguns professores com a comunidade atendida e dizia que a opção da escola seria a autonomia para selecionar os professores para a mesma. A justificativa é que a comunidade atendida tinha características especiais (demonstrações de miséria, de violência, de abuso sexual, etc) que demandavam sensibilidade e comprometimento específicos, o que não se verificava em todos os professores. Esse reclame, principalmente dos diretores, em possuir autonomia para selecionar os professores, relacionando seu perfil com as características específicas da instituição, foi verificado na outra escola também.

Essa medida, de atribuição de autonomia às escolas selecionarem seus professores, demonstraria um grau de descentralização de poder de decisão significativo para as escolas e poderia favorecer a busca pela qualidade do ensino através da consideração da realidade escolar e do reconhecimento da comunidade escolar como sujeitos conhecedores e construtores de sua própria história escolar.

Ainda segundo a entrevista da diretora, a implementação da eleição de diretores (1984) contribuiu para que a SEED criasse mecanismos burocráticos de controle, o que caracterizou uma aguda centralização de poder. De acordo com a entrevistada, isso se justificava porque, no período em que os diretores detinham "cargos de confiança" não era necessário tal controle porque eles seguiam as orientações da SEED sem questionamento.

Com a ocupação dos cargos por eleição, a SEED instalou outras estratégias que garantissem semelhante controle nas ações dos diretores, inviabilizando a descentralização de poder da SEED para os diretores. Supõe-se ser paradoxal, pois a eleição de diretores que é uma forma de democracia direta implementada nas escolas estaduais e deveria traduzir-se numa conseqüente descentralização do poder da SEED aos novos representantes da comunidade escolar (os diretores), acabou por configurar numa manobra política que mudou a "roupagem" para a escolha de diretores, mas a essência controladora permanece. É uma modernização de um estado/essência conservador (a).

No interior da escola reproduziam-se controle e centralidade nas decisões, embora isso fosse criticado por alguns entrevistados, quando as alternativas para 
solucionar situações-problema e estabelecer normas se restringiam à equipe pedagógica e à direção.

As normas quem determina é a direção mais a supervisa e, a orientação no início do ano, antes de começar a aula (...). (Funcionário da escola)

Exemplo disso, conforme relato do funcionário Aparecido, foram as reivindicações que os professores fizeram no período de campanha para eleição de diretores, entre as quais constava que os professores tivessem autonomia, que ele fosse ouvido e que a cota do "xerox" fosse determinada de acordo com a necessidade de cada disciplina. O não-atendimento dessas reivindicações caracterizou-se num exemplo de desconsideração para com a comunidade interna e externa da escola e de centralidade de poder.

A descentralização de poder do Estado por intermédio da SEED, para os NRE e para as escolas está longe de acontecer, realidade que pode ser percebida na pesquisa de campo. $O$ que realmente se verificou foi a centralidade nas decisões e o controle, muitas vezes camuflado, por parte dos órgãos superiores. Para tanto, seria necessária uma organização coletiva, uma consciência dos objetivos comuns e uma pressão sobre os órgãos superiores caracterizando, assim, uma conquista gradual da autonomia e conseqüente processo de descentralização do poder. 


\section{CONSIDERAÇÕES FINAIS}

A política educacional do Paraná no governo de Jaime Lerner (1995-2002) foi marcada por um modelo de gestão pública que reformou todo o aparato do Estado no sentido de torná-lo enxuto, fragmentado, mas centralizado em um núcleo pequeno de tecnocratas oriundos do setor privado da economia. Os princípios da administração privada foram assimilados em todas as instituições estatais de caráter econômico ou social. A modernização conservadora pôde associar as mais sofisticadas formas de dominação do capital com uma incipiente estrutura pública de serviços de infraestrutura e de atendimento social, tais como a saúde e a educação.

As reformas na gestão do sistema de ensino e das escolas foram anunciadas como um aprofundamento do processo de democratização coerente com as versões liberais americanas. Entretanto, a gestão em si tornou-se a essência das relações sociais e não os mecanismos a serviço do que poderia ser um processo de democratização social, no sentido da igualdade social e não apenas da dinamização da competição social. Nesse sentido a gestão tornou-se fetiche, o milagre que poderia modernizar a educação no Paraná, criando-se centenas de cursos por ano sobre gestão da escola, da sala de aula, da APM, da comunidade, dos recursos humanos, dos clientes, do currículo, da qualidade de vida, etc, etc...A promessa era de que todos os problemas das escolas seriam resolvidos com uma "boa" gestão capaz de motivar os alunos, professores e funcionários das escolas a reproduzirem a escola possível: se pobre e sem recursos, mas bem enfeitada, com todos animados reciclando lixos e limpando carteiras; se rica e com recursos (dos pais da classe de renda média), requintada com ar-condicionado, segurança, carteiras finas, com alunos orgulhosos de estudar na escola classificada no primeiro lugar do ranking das melhores escolas. A gestão eficiente conseguiria apagar qualquer desigualdade social e educacional. Afinal, o sistema estava oferecendo modelos de gestão modernos e quase "mágicos".

O "feitiço" não durou muito tempo, porque a realidade é algo que se impõe aos sujeitos envolvidos, sobretudo àqueles inseridos nas escolas não-consideradas de "excelência" e aí encontram-se sentimentos de frustração, complexo de inferioridade, além de críticas e embriões de resistência. Resistência ao fetiche, à mentira quando se diz que tudo se resume a problemas de gestão, que as desigualdades de classes sociais não interferem na qualidade da escola e que o Estado não deve intervir como 
principal provedor e financiador da educação. Por isso, a compreensão da política educacional nos oito anos do governo de Jaime Lerner necessita da análise do modelo de gestão escolar implementado.

Foi instaurado o modelo de gestão compartilhada nas escolas estaduais. Ele consistia em associar: 1) racionalização técnica e financeira, 2) promessa de melhoria da qualidade do ensino mesmo com a escassez de recursos, 3) centralização das decisões (de forma velada) combinada com a descentralização financeira e de tarefas preestabelecidas, 4) estímulo à privatização das escolas públicas, 5) ressignificação de pressupostos advindos das camadas populares num contexto de redemocratização da sociedade, tais como democracia, gestão democrática, participação, autonomia e descentralização, adaptados à dinâmica do mercado, como estratégia de obtenção da hegemonia neoliberal.

Foi possível diagnosticar incoerência entre discurso e prática e fragilidade do conceito de democracia inerente ao modelo de gestão proposto pela SEED. Cobra-se das escolas um trabalho coletivo, participativo e autônomo. No entanto, determinam-se orientações verticalizadas e autoritárias, além de se escamotearem os aspectos políticos, econômicos e sociais do modelo de gestão instalado que garante a alienação e a dominação consentida.

Durante o processo desta pesquisa foi possível elaborar argumentos, esclarecer conceitos, relacionar e pensar o concerto vivido e a tentativa e exercício de sistematização do concreto pensado.

Um dos principais aprendizados adquiridos diz respeito ao aspecto teóricometodológico por ter confirmado a complexidade e a contraditoriedade da realidade empírica, quando se percebe, nas escolas, incontáveis práticas nem sempre coerentes.

Entretanto, é possível afirmar que a escola Domingas Guerreiro da Silva estava mais propensa a uma busca de mudança, pois apresentava certa desalienação diante de algumas orientações do governo de Jaime Lerner. Os sujeitos entrevistados desta escola demonstraram comprometimento com a democratização da escola pública e, por isso, desconsideravam a orientação para o trabalho voluntário, por exemplo, inserida no documento PQE (1994).

Já a escola Maria do Rosário Soares Brasil, embora não seja possível rotulá-la ou classificá-la como conservadora, demonstrou, de acordo com a pesquisa de campo, uma adesão maior ao modelo de gestão compartilhada, muito embora tenha 
apresentado práticas de resistência também. O que se pode afirmar é que a maioria das práticas percebidas direcionava-se para tal modelo, pois era muito comum a centralização das decisões conjugada com a descentralização das tarefas e o provimento de condições objetivas pela comunidade externa. Exemplo disso é a falta de espaços coletivos decisórios e a utilização exagerada do trabalho voluntário e de alocação de recursos privados.

Para a instauração de um processo de democratização do ensino público, seria necessária uma organização coletiva, uma consciência dos objetivos comuns e uma pressão sobre os órgãos superiores, o que caracterizaria uma conquista gradual da autonomia e, conseqüentemente, um processo de descentralização do poder.

Entretanto, se não forem explorados os espaços de participação, se não se começar a discutir assuntos pedagógicos, por exemplo, com a comunidade, não se irá exercitar a tão propalada democracia. Ela só é conquistada mediante seu exercício, e para tanto, mesmo em condições não-ideais, é fundamental criar condições, desde a sala de aula até a gestão do sistema de ensino, para o exercício pleno da democracia, que pressupõe enfrentar conflitos diariamente, assumir os riscos conjuntamente, ter 0 financiamento garantido para que o tempo dos líderes administradores seja gasto com problemas do ensino, da educação propriamente dita. Isso seria completamente diferente do fetiche da gestão compartilhada, em que se escondem os conflitos, não se garantem os recursos para a sobrevivência da instituição, e empulsionam-se todos a gastarem energia arrecadando fundos para que a escola não feche as portas.

Estudar o modelo de gestão implementado nesses oito anos de reformas no Estado e na educação permitiu desmistificar a gestão compartilhada, indicando sua essência antidemocrática, arquitetada sob a capa de modernização e transformação, fetichizando-se a dimensão da gestão, como se ela fosse o elixir para todos os problemas da escola.

A alteração na política educacional poderá provocar mudanças nos modelos de gestão da escola e isso dependerá da concepção de Estado, Sociedade e Educação dos grupos com poder de decisão na burocracia educacional. A gestão compartilhada só será superada num processo de hegemonia de um modelo de democracia que ganhe corpo no aparato do Estado e direcione a organização das escolas dando poder real aos professores, alunos, pais através de mecanismos que efetivem o envolvimento 
nas questões pedagógicas e administrativas, estando estas últimas subordinadas aos princípios e necessidades pedagógicas e não o inverso. 


\section{REFERÊNCIAS BIBLIOGRÁFICAS}

ARROYO, Miguel Gonzalez. Fracasso-sucesso: o peso da cultura escolar e do ordenamento da educação básica. Em Aberto, Brasília, ano 11, n 53, jan/mar. 1992. ARROYO, Miguel Gonzalez. A administração da educação é um problema político. Revista Brasileira de administração da educação. Porto Alegre, v. 1, n. 1, p. 122-129, jan/jun. 1983.

ADRIÃO, Theresa Maria de Freitas. Autonomia monitorada como eixo de mudança: padrões de ensino público paulista (1995-1998). São Paulo, 2001. Tese de doutorado em educação pela Universidade de São Paulo - USP.

BENEVIDES, Maria Victoria de Mesquita. Cidadania e democracia. Lua Nova, no.33, 1994.

BOBBIO, Norberto. Estado, governo, sociedade. Para uma teoria geral da política. Paz e Terra, 2001.

BOBBIO, Norberto. Democracia. In: BOBBIO, Norberto; MATEUCCI, Nicola; PASQUINO, Gianfranco. Dicionário de política. Brasília: Universidade de Brasília, 1986. BOTTOMORE, Tom. Dicionário do pensamento marxista. Rio de Janeiro: Jorge Zahar, 2001.

BUENO, Maria Sylvia Simões. Gestão de Sistemas Educativos e Unidades Escolares: qualidade de ensino e educação democrática. (mesa redonda - 06/06/2001) BORDENAVE, Juan E. Diaz. O que é participação. São Paulo: Brasiliense, 1983. CAMARGO, Rubens Barbosa de. Gestão democrática e qualidade do ensino: o conselho da escola e a interdisciplinaridade nas escolas municipais de São Paulo (1989-1992). São Paulo, Feusp, tese de doutorado, 1996.

CAMARGO, Rubens Barbosa de. ADRIÃO, Theresa. A gestão democrática na constituição federal de 1988. In: OLIVEIRA, Romualdo Portela de. ADRIÃO, Theresa. Gestão financiamento e direito à educação. Análise da LDB e da constituição federal. São Paulo: Xamã, 2001.

CATTANI, Antônio David (org.). Dicionário crítico de trabalho e tecnologia. Petrópolis: Vozes e Porto Alegre: Ed. Universidade Federal do Rio Grande do Sul, 1997.

CHEFFLER, Israel. A linguagem e educação. Tradução de Balthazar Barbosa Filho São Paulo: Editora da Universidade de São Paulo e Edição Saraiva, 1974 
COUTINHO, Carlos Nelson. Democracia e socialismo: questões de princípio. In: Contra a corrente. Ensaios sobre democracia e socialismo. São Paulo: Cortez, 2000.

CUNHA, Luiz Antônio. Educação, Estado e democracia no Brasil. São Paulo: Cortez; Niterói : Editora da Universidade Federal Fluminense; Brasília: Flacso do Brasil, 1995. CURY, Carlos R. Jamil. Educação e contradição. São Paulo: Cortez: Autores Associados, 1986.

CZERNISZ, Eliane Cleide da Silva. "Gestão democrática" da escola pública: Um movimento de "abertura" da escola à participação da comunidade? Dissertação de mestrado. Maringá: UEM (Universidade Estadual de Maringá), 1999.

DALLARI, Dalmo de Abreu. O que é participação política. 9 ${ }^{a}$. edição. São Paulo: Brasiliense, 1991.

FELIX, Maria de F. C. Administração escolar: um problema educativo ou empresarial. São Paulo: Cortez, 1989.

FILHO, Lourenço. Organização e administração escolar. São Paulo: Melhoramentos, 1976.

FREIRE, Paulo. Educação e atualidade brasileira. Tese de concurso para cadeira de história e filosofia da educação na escola de Belas Artes de Pernambuco. Recife, 1959. FRIGOTO, Gaudêncio. Educação e a crise do capitalismo real. São Paulo: Cortez, 1995.

GENTILI, Pablo. A falsificação do consenso. Simulacro e imposição na reforma educacional do neoliberalismo. Petrópolis RJ: Vozes, 1998.

GENTILI, Pablo A. A. SILVA, Tomaz Tadeu da (orgs). Neoliberalismo, qualidade total e educação. Petrópolis: Vozes, 1994.

GONÇALVES, Maria Dativa Salles. Autonomia da escola e neoliberalismo: Estado e escola pública. São Paulo, 1994. Tese de doutorado em educação - Pontifícia Universidade Católica -PUC.

GORNI, Doralice Aparecida Paranzini. Sistema Estadual de Educação do Paraná: qualidade e avaliação. Tese de doutorado. Universidade Estadual Paulista Júlio de Mesquita Filho, 1999.

GRAMCI, Antônio. Os intelectuais e a organização da cultura. Rio de Janeiro: Civilização Brasileira, 1988. 
HIDALGO, Ângela Maria. Tendências contemporâneas da privatização do ensino público: o caso do Paraná. São Paulo, 1998. Dissertação de mestrado. Pontifícia Universidade Católica-PUC.

HIDALGO, Angela Maria ET ALL. A Gestão Democrática Educacional na redefinição do papel do estado.In: NOGUEIRA, Francis Mary Guimarães (org.) Estado e Políticas Sociais no Brasil. Cascavel: EDUNIOESTE,2001.

HIDALGO, Angela Maria. Tendências Contemporâneas da Privatização do Ensino Público: O Caso do Estado do Paraná. In: HIDALGO, Angela Maria.; SILVA, lleizi Luciana Fiorelli (orgs). Educação e Estado: As Mudanças nos Sistemas de Ensino do Brasil e Paraná na déc. de 90. Londrina: Ed. UEL, 2001.

KAMMI, Constance. A autonomia como finalidade da educação: implicações da teoria de Piaget. IN: KAMMI, Constance. A criança e o número. Tradução: Regina a de Assis. $11^{\mathrm{a}}$. edição. Campinas: Papirus, 1990.

KOSIK, Karel. Dialética do concreto. Rio de Janeiro: Paz e Terra, 1969.

KRAWCZYK, Nora Rut. Em busca de uma nova governabilidade na educação. IN:

LARANJEIRA, Sônia M. G. Programa de Qualidade Total. In: CATTANI, Antônio David. Dicionário crítico de trabalho e tecnologia. 1997. p. 183-190.

LIMA, Licínio. A escola como organização educativa. São Paulo: Cortez, 2001.

LIMA, Licínio. Democracia radical e pedagogia democrática: organização e participação como práticas da liberdade. In: Organização escolar e democracia radical. Paulo Freire e a governação democrática da escola pública. São Paulo: Cortez: Instituto Paulo Freire, 2000.

LUDKE, Menga. ANDRÉ,Marli E. A. Pesquisa em educação: abordagens qualitativas.São Paulo: EPU, 1986.

MACHADO, Lourdes Marcelino. Quem "Embala" a Escola ? Considerações a Respeito da Gestão da Unidade Escolar. In: MACHADO, Lourdes M. (coord.)

MACHADO, Lucília R. de Souza. Politecnia, escola unitária e trabalho. São Paulo: Cortez e Ed. Autores Associados, 1991.

MARTINS, Ângela Maria. Autonomia e gestão da escola pública: aportes para uma discussão. IN: OLIVEIRA, Dalila Andrade, ROSAR, Maria de Fátima Félix (orgs). Política e gestão da educação. Belo Horizonte: Autêntica, 2002. 
OLIVEIRA, Dalila Andrade. Mudanças na organização e na gestão do trabalho na escola. IN: OLIVEIRA, Dalila Andrade; ROSAR, Maria de Fátima Félix (orgs).Política e gestão da educação. Belo Horizonte: Autêntica, 2002.

OLIVEIRA, Romualdo Portela. A municipalização do ensino no Brasil. In: OLIVEIRA, Dalila Andrade (org.) Gestão democrática da educação. Petrópolis: Vozes, 1997.

OLIVEIRA, Dalila Andrade; ROSAR, Maria de Fátima Félix (orgs).Política e gestão da educação. Belo Horizonte: Autêntica, 2002.

PALADINI, Edson Pacheco. Qualidade Total na prática. Implantação e avaliação de sistemas de qualidade total. São Paulo: Atlas, 1994.

PARO, Vitor Henrique. Administração escolar: introdução crítica. São Paulo: Cortez e Autores Associados, 1986..

PARO, Vitor Henrique. Escritos sobre educação. São Paulo: Xamã, 2001.

PARO, Vitor Henrique. Qualidade do ensino: a contribuição dos pais. São Paulo, 2000.

PARO, Vitor Henrique. Gestão da escola pública: a participação da comunidade. In: Paro, Vitor Henrique. Gestão democrática da escola pública. São Paulo: Ática, 1997.

PARO, Vitor Henrique. O princípio da gestão escolar democrática no contexto da $L D B$. In: OLIVEIRA, Romualdo Portela de. ADRIÃO, Theresa. Gestão financiamento e direito à educação. Análise da LDB e da constituição federal. São Paulo: Xamã, 2001.

PARO, Vitor Henrique. Gestão Escolar, Ética e Liberdade. São Paulo: Cortez, 2000.

PIMENTA, Selma Garrido. O pedagogo na escola pública. São Paulo: Edições Loyola, 1988.

RIBEIRO, José Querino. Ensaio de uma teoria da administração escolar. São Paulo: Saraiva, 1978.

ROSAR, Maria de Fátima Félix; OLIVEIRA, Dalila Andrade (orgs). Política e gestão da educação. Belo Horizonte: Autêntica, 2002.

ROSAR, Maria de Fátima Félix. A municipalização como estratégia de descentralização e desconstrução do sistema brasileiro. In: OLIVEIRA, Dalila Andrade (org.) Gestão democrática da educação. Petrópolis: Vozes, 1997.

SANDER, Benno. Administração da educação no Brasil: evolução do conhecimento. Fortaleza, edições UFC; Brasília, ANPAE, 1982.

SANTOS, Jussara Maria Tavares Puglielli. As políticas governamentais para o ensino fundamental do Paraná diante dos preceitos da constituição. Tese de doutorado em educação. USP: São Paulo, 1998. 
SAPELLI, Marlene Lucia Siebert. Políticas educacionais do governo Lerner no Paraná (1995-2002). Cascavel: Gráfica Igol, 2003.

SAVIANI, Dermeval. Escola e democracia. São Paulo: Cortez e Autores associados, 1983.

SGUISARDI,Valdemar e SILVA Jr; João dos Reis. Novas faces da educação superior no Brasil. Reforma do Estado e Mudanças na produção. São Paulo: Cortez e Bragança Paulista, SP.

SILVA, Ileizi Luciana Fiorelli. Reforma ou Contra Reforma no Sistema de Ensino do Estado do Paraná ? uma análise da meta da igualdade social nas políticas educacionais dos anos 90. Dissertação de mestrado em educação. USP, 1998.

SOBRINHO, José Amaral; XAVIER, ANTÔNIO Carlos da R.; MARRA, Fátima. Gestão Escolar: desafios e tendências. Brasília: Instituto de Pesquisa Econômica Aplicada IPEA, 1994.

SOUZA, Antônio Lisboa Leitão de. Estado e educação pública: tendências administrativas e de gestão. IN: OLIVEIRA, Dalila Andrade; ROSAR, Maria de Fátima Félix (orgs).Política e gestão da educação. Belo Horizonte: Autêntica, 2002.

SOUZA, Silvana Aparecida de. Gestão escolar compartilhada. Democracia ou descompromisso? São Paulo: Xamã, 2001.

SCHEINOWITZ, A . S. A descentralização do Estado. Brasília:Brasília Jurídica, 1992.

TORRES, Rosa Maria. Melhorar a qualidade da educação básica? As estratégias do Banco Mundial. IN: TOMASI, Lívia de; WARDE, Mirian Jorge; HADDAD, (orgs). O Banco Mundial e as políticas educacionais. São Paulo: Cortez; PUC -S.P.; Ação Educativa, 1996.

TZENG, Lin Cheng Wen. Gerência da Qualidade Total em Educação. IN: VIEIRA, Evaldo. Democracia e política social. São Paulo: Cortez e Autores Associados, 1992.

\section{DOCUMENTOS}

PQE (Projeto Qualidade do Ensino Público do Paraná,1995-2001),

PROEM (Projeto ensino médio),

PEE (Plano Estadual de Educação, 1997)

Avaliação qualitativa de mecanismos de descentralização escola (1998)

Avaliação do Impacto da Municipalização do Ensino Fundamental no Estado do Paraná (1996), Relatório Final do PQE (2002) 
Dez anos de Educação no Paraná (2001)

Guia de Gestão Escolar (2002)

Entendendo melhor a mudança organizacional (1996)

Caderno: Centro de capacitação de Faxinal do Céu: Universidade do Professor (1998).

PARANÁ. SECRETARIA DE ESTADO DA EDUCAÇÃO. Superintendência de Educação. Construindo a escola cidadã. Curitiba: SEED-PR, 1992. 
ANEXOS

\section{ROTEIRO DE ENTREVISTAS}

\section{Concepção dos modelos de gestão democrática e compartilhada}

1) O que entende por democracia?

2) Considera possível uma escola pública democrática?

3) O que você entende por gestão escolar?

4) $\mathrm{O}$ que você entende por gestão democrática? Quais são suas características principais?

5) No que consiste o trabalho da direção da escola? Ela é nomeada ou eleita? Se eleita, como foi o processo eleitoral?

6) O que você entende por gestão compartilhada?

7) Quais as diferenças entre a sua concepção de gestão e da SEED?

8) Quais os documentos, as correspondências da SEED-PR que revelam o tipo de gestão desejada pelo governo estadual? Leu tais documentos? Como eles são socializados para a comunidade escolar?

9) Os cursos de formação em Faxinal do Céu sobre gestão contribuíram para seu crescimento como profissional? Em que sentido? Mudou a sua concepção e prática de gestão escolar? O quê?

10) Como a escola recebe e implementa as orientações e determinações da SEED e NRE?

11) Considera essa proposta de gestão adequada para a realidade da escola? Por quê?

12) Indique pelo menos três pontos positivos e três pontos negativos na proposta de gestão do governo estadual.

13) Tem utilizado instrumentos ou algum tipo de material para modernizar a gestão de sua escola? Quais?

14) O Estado tem proposto, nos oito últimos anos, o perfil da escola de excelência. Como você vê essa questão da busca pela excelência?

15) A sua escola se preocupa em concorrer a esse status? Como? 
16) Que elementos considera essenciais para uma gestão escolar de excelência?

\section{Autonomia e descentralização}

17) $O$ que entende por autonomia? Considera que sua escola possui autonomia?

18) Possui autonomia de gestão financeira? Como isto se dá na prática? Exemplifique.

19) Possui autonomia pedagógica? Como isto se dá na prática? Exemplifique.

20) Possui autonomia administrativa? Como isto se dá na prática? Exemplifique.

21) Na ausência do diretor, quando surgem problemas e/ou dificuldades, como e por quais sujeitos eles são resolvidos?

22) As decisões administrativas e financeiras são tomadas em que espaço e por quais sujeitos? Como são operacionalizadas? Quando não conseguem pôr em prática as decisões tomadas, o que as impede?

23) AS decisões pedagógicas são tomadas em que espaço e por quais sujeitos? Como elas são operacionalizadas? Quando não são colocadas em prática, por quais motivos não o são?

24) O que impede ou facilita a conquista da autonomia pedagógica, administrativa e financeira?

25) Quais as fontes de recursos para a manutenção da escola?

26) Em que medida a falta de recursos (material e pessoal) compromete a realização do PPP e o exercício da autonomia?

27) O que é projeto político pedagógico? Como foi elaborado em sua escola? Quem participou ativamente na sua elaboração?

28) As considerações que aparecem no PPP são levadas em consideração no planejamento das atividades escolares ao longo do ano letivo? De maneira consciente, ou seja, os professores e equipe pedagógica buscam uma coerência entre a sua prática e o PPP da escola? Lutam por sua reformulação, se for o caso?

29) Qual é a maior preocupação em relação ao processo de ensino e aprendizagem? 
30) Quais as principais dificuldades enfrentadas em seu trabalho?

31) Quais os principais motivos de conflitos e divergências na sua escola?

\section{Participação}

32) Como se dá a participação na sua escola? Quais os canais de participação? Quem e como participam os sujeitos na:

- $\quad$ organização do trabalho da escola

- $\quad$ nas decisões administrativas

- $\quad$ nas decisões pedagógicas

- $\quad$ nas decisões financeiras

33) A escola já fez algum tipo de parceria tais como: amigos da escola, empresas,convênios com entidades ou instituições, etc.

34) A escola já concorreu a algum prêmio de excelência? Considera importante este tipo de participação? Por quê?

MEMBROS DA APM E CE (todas as questões acima, com linguagem menos específica, mais estas)

1) Qual é o trabalho desenvolvido pela APM e/ou Conselho escolar?

2) Por que está participando da APM e/ou conselho escolar?

3) Quais são as dificuldades encontradas para realizar o trabalho que a APM e/ou CE se propõem a fazer?

4) Conhece a proposta pedagógica da escola?

5) Conhece as orientações vindas da SEED para a gestão escolar?

6) Em que mais a APM e/ou CE poderia contribuir para a escola?

7) Como se dá a relação com a equipe administrativa e pedagógica da escola?

\section{ROTEIRO DE OBSERVAÇÃO}

1) Caracterização da escola;

2) Descrição do perfil do diretor e processo de posse do cargo;

3) Organização do trabalho na escola (estrutura, objetivos e relações interpessoais);

4) Atendimento ao público e suas formas de relacionamento; 
5) Estrutura física (condições gerais, equipamento pedagógico, espaço físico,etc);

6) Número de funcionários e professores e as qualificações, número de turmas, equipe pedagógica;

7) Analisar o PPP da escola, o regimento escolar e os documentos da SEED recebidos na escola;

8) Relações horizontais ou verticais nos âmbitos administrativo e pedagógico;

9) Dinâmica nas reuniões de: CE, APM, CC, equipe pedagógica e professores;

10) Formas de participação, sujeitos envolvidos e dinâmica de discussão. 